Prepared in cooperation with the Washington State Department of Ecology, Stormwater Action Monitoring (SAM) Program

\title{
Nearshore Sediment Monitoring for the Stormwater Action Monitoring (SAM) Program, Puget Sound, Western Washington
}

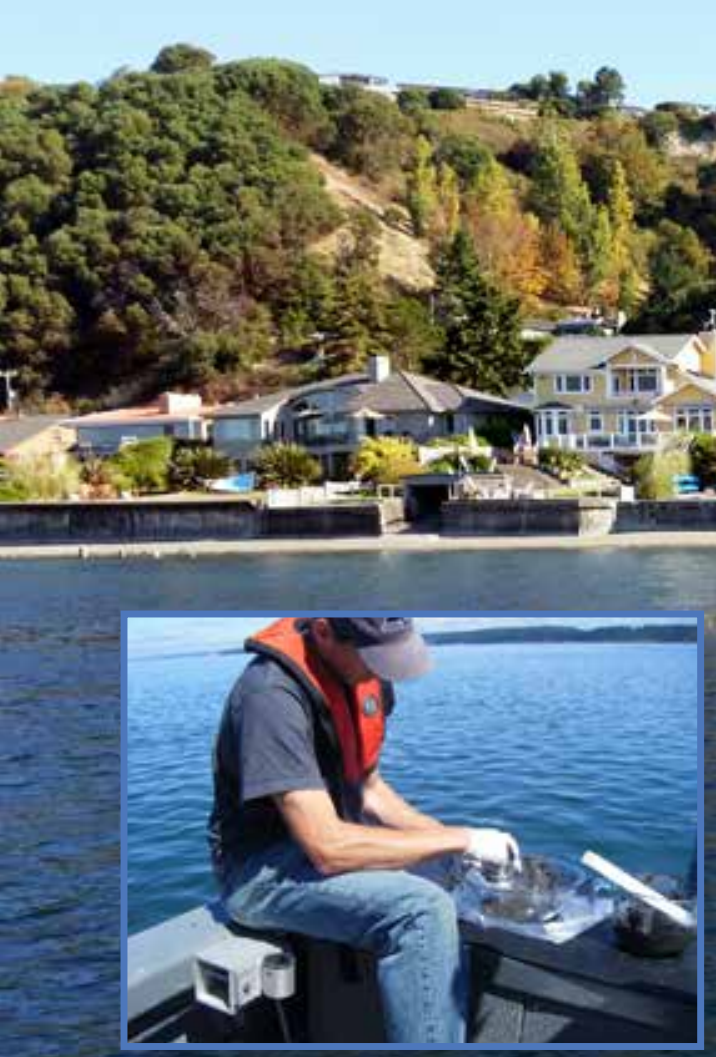

Scientific Investigations Report 2018-5076 
Cover: Photographs showing Puget Sound nearshore sediment sampling site west of Everett, Washington, and processing of sediment sample for organic chemicals (inset).

Photographs by Brandi Lubliner, Washington State Department of Ecology, September 13, 2016

(sediment sampling site), and Abby Barnes, Washington State Department of Natural Resources, August 10, 2016 (inset). 


\section{Nearshore Sediment Monitoring for the Stormwater Action Monitoring (SAM) Program, Puget Sound, Western Washington}

By Robert W. Black, Abby Barnes, Colin Elliot, and Jennifer Lanksbury

Prepared in cooperation with the Washington State Department of Ecology, Stormwater Action Monitoring (SAM) Program

Scientific Investigations Report 2018-5076 


\title{
U.S. Department of the Interior \\ RYAN K. ZINKE, Secretary
}

\author{
U.S. Geological Survey \\ James F. Reilly II, Director
}

U.S. Geological Survey, Reston, Virginia: 2018

For more information on the USGS - the Federal source for science about the Earth, its natural and living resources, natural hazards, and the environment—visit https://www.usgs.gov or call 1-888-ASK-USGS.

For an overview of USGS information products, including maps, imagery, and publications, visit https://store.usgs.gov.

Any use of trade, firm, or product names is for descriptive purposes only and does not imply endorsement by the U.S. Government.

Although this information product, for the most part, is in the public domain, it also may contain copyrighted materials as noted in the text. Permission to reproduce copyrighted items must be secured from the copyright owner.

Suggested citation:

Black, R.W., Barnes, A., Elliot, C., and Lanksbury, J., 2018, Nearshore sediment monitoring for the Stormwater Action Monitoring (SAM) Program, Puget Sound, western Washington: U.S. Geological Survey Scientific Investigations Report 2018-5076, 53 p., https://doi.org/10.3133/sir20185076.

ISSN 2328-0328 (online) 


\section{Contents}

Abstract

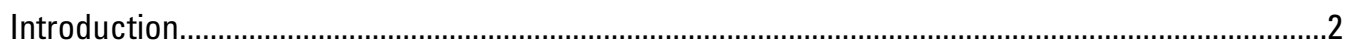

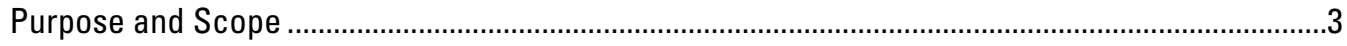

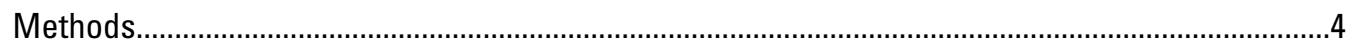

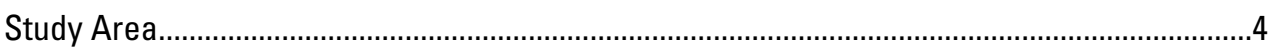

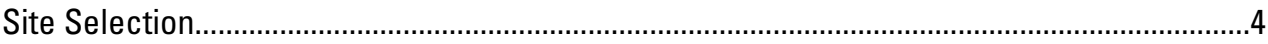

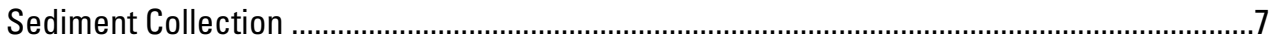

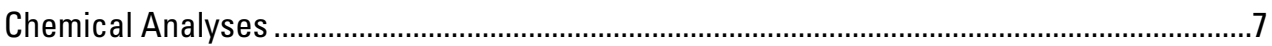

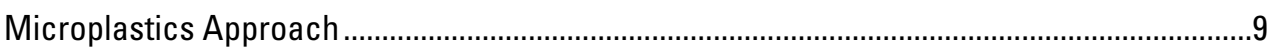

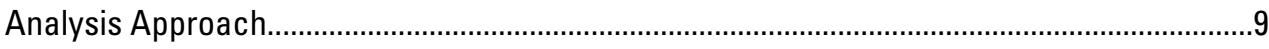

Summary Statistics for Chemicals ...................................................................................

Extrapolating Sediment Chemical Concentration Results to the Puget Sound Urban Nearshore Scale ...............................................................................10

Effects of Land Cover and Geologic Features on Sediment Quality.........................10

Effects of Marine Hydrodynamics on Sediment Quality ........................................11

Comparison with Mussel and Other Sediment Results............................................12

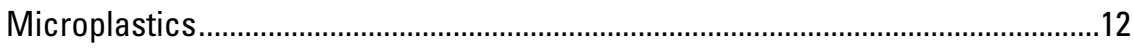

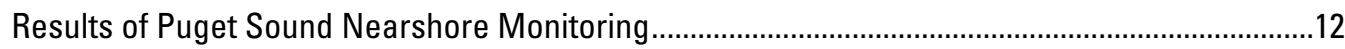

Polychlorinated Biphenyl Concentrations and Extrapolation to the Stormwater Action Monitoring Nearshore .......................................................................................12

Polybrominated Diphenyl Ether Concentrations and Extrapolation to the Stormwater Action Monitoring Nearshore .................................................................................14

Polycyclic Aromatic Hydrocarbon Concentrations and Extrapolation to the Stormwater

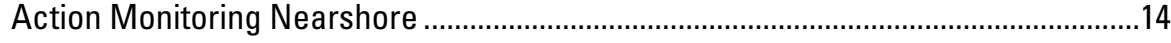

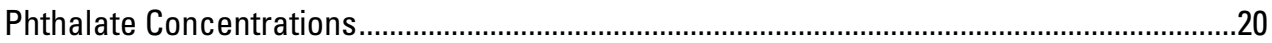

Metal Concentrations and Extrapolation to the Stormwater Action Monitoring

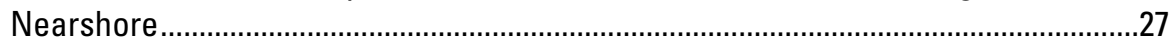

Sediment Chemistry Concentrations in Relation to Land-Use and Geologic Features...........27

Effects of Marine Hydrodynamics on Sediment Quality ........................................................32

Sediment Compared to Mussel Tissue Concentrations ............................................................36

Nearshore Sediment Compared to Other Sediment Sampling Programs ..................................36

Organic Compound Comparisons ........................................................................................36

Individual Polycyclic Aromatic Hydrocarbons ................................................................36

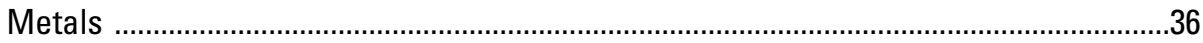

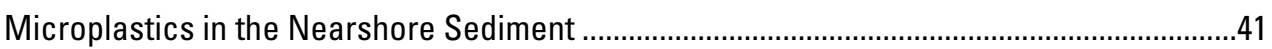

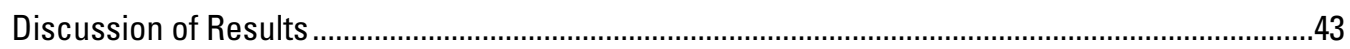

Considerations for Future Nearshore Sediment Work …….........................................................45

Summary

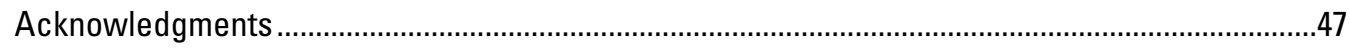

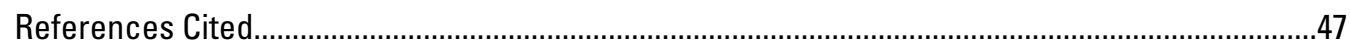

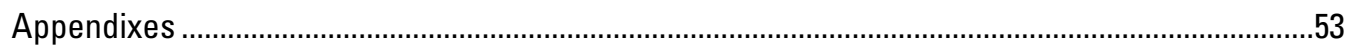




\section{Figures}

1. Map showing Puget Sound urban nearshore study area, Puget Sound, western Washington.

2. Map showing sampling site locations, Puget Sound urban nearshore study area, Puget Sound, western Washington

3. Boxplots and summary statistics showing percentage of the 209 polychlorinated biphenyl (PCB) congeners, and total and total organic carbon-normalized total PCB concentrations, detected at the 41 nearshore sediment sites, Puget Sound, western Washington.

4. Boxplots and summary statistics showing percentage of the 12 most toxic polychlorinated biphenyl (PCB) congeners, and total and total organic carbon-normalized total of the 12 most toxic PCB congener concentrations, detected at the 41 nearshore sediment sites, Puget Sound, western Washington

5. Boxplot and summary statistics for the 12 most toxic polychlorinated biphenyl congeners represented as a Toxicity EQuivalent concentration of 2,3,7,8-tetrachorodibenzo-p-dioxin at the 41 nearshore sediment sites, Puget Sound, western Washington.

6. Cumulative distribution function plots showing concentrations of total polychlorinated biphenyls (PCBs) of 209 congeners, and Toxicity EQuivalent concentration of the 12 most toxic PCBs in sediment, from 41 study sites extrapolated to represent 1,344 kilometers of shoreline of Puget Sound Urban Growth Area, western Washington

7. Boxplot and summary statistics showing percentage of the 48 polybrominated diphenyl ether (PBDE) congeners, and total and total organic carbon-normalized total PBDE concentrations, detected at the 41 nearshore sediment sites, Puget Sound, western Washington.

8. Cumulative distribution function plot showing concentrations of total polybrominated diphenyl ethers in sediment from 41 study sites, representing 1,344 kilometers of shoreline of the Puget Sound Urban Growth Area, western Washington.

9. Boxplot and summary statistics showing percentage of the 42 polycyclic aromatic hydrocarbon (PAH) compounds, and total and total organic carbon-normalized total PAH concentrations, detected at the 41 nearshore sediment sites, Puget Sound, western Washington.

10. Cumulative distribution function plot showing concentrations of total polycyclic aromatic hydrocarbons in sediment from 41 study sites, representing 1,344 kilometers of shoreline of the Puget Sound Urban Growth Area, western Washington

11. Cumulative distribution function plots showing concentrations of 15 polycyclic aromatic hydrocarbons with Washington State marine sediment criteria in sediment from 41 study sites representing 1,344 kilometers of shoreline of the Puget Sound Urban Growth Area, western Washington

12. Cumulative distribution function plots showing concentrations of seven select metals in sediment from 41 study sites representing 1,344 kilometers of shoreline of the Puget Sound Urban Growth Area, western Washington 


\section{Figures-Continued}

13. Boxplots showing concentrations of total polychlorinated biphenyls (PCBs), total of the 12 most toxic PCB congeners, total polybrominated diphenyl ethers, and total polycyclic aromatic hydrocarbons, compared to drift cell types, Puget Sound, western Washington.

14. Boxplots showing concentrations of arsenic, cadmium, chromium, copper, lead, mercury, and zinc compared to drift cell types, Puget Sound, western Washington.

15. Graphs showing concentrations of total polychlorinated biphenyls (PCBs), and total polycyclic aromatic hydrocarbons (PAHs) in sediment compared to total PCBs and PAHs, respectively, in mussel tissue, Puget Sound, western Washington ....37

16. Graphs showing metal concentrations in sediment compared to metal concentrations in mussel tissue, Puget Sound, western Washington.

17. Boxplots showing percentage of sediment sample composed of small particles of clay, silt, and sand, and total organic carbonfrom the Stormwater Action Monitoring nearshore study, 2016, and the Puget Sound Ecosystem Monitoring Program, Puget Sound, western Washington, 2002-14

18. Graphs showing concentrations of total polychlorinated biphenyls, total polybrominated diphenyl ethers, and total polycyclic aromatic hydrocarbons in sediment sampled for the Stormwater Action Monitoring nearshore study, 2016, and the Puget Sound Ecosystem Monitoring Program, Puget Sound, western Washington, 2002-14...

19. Boxplots showing density of microplastics in nearshore sediments by drift cell and fiber type, and size, Puget Sound, western Washington

\section{Tables}

1. Sites sampled as part of the Stormwater Action Monitoring Nearshore Sediment Status and Trends sampling, Puget Sound, western Washington

2. Compound-specific maximum concentrations at various percentages of Urban Growth Area nearshore shoreline represented by the Stormwater Action Monitoring sediment study, Puget Sound, western Washington

3. Summary statistics for concentrations of polycyclic aromatic hydrocarbon compounds, with corresponding Washington State sediment criteria, collected at the 41 Stormwater Action Monitoring sampling sites, and sediment samples collected as part of the Puget Sound Ecosystem and Monitoring Program, Puget Sound, western Washington, 2002-14

4. Summary statistics for phthalate concentrations with Washington State sediment criteria from 41 Stormwater Action Monitoring sampling sites, Puget Sound, western Washington

5. Summary statistics for metal concentrations for 41 Stormwater Action Monitoring sampling sites and sediment samples collected as part of the Puget Sound Ecosystem and Monitoring Program, Puget Sound, western Washington, 2002-14 ......27 


\section{Tables-Continued}

6. Stepwise linear regression results for relation between sediment chemical concentrations and land-use and geologic features

7. Results of Random Forest analysis to determine if one or more land-use, geologic, or physical variables recorded at each of the 41 nearshore sediment sites were related to each of the chemical concentrations in Puget Sound, western Washington. .31

8. Results of statistical tests to determine if sediment polycyclic aromatic hydrocarbon concentrations are significantly different between drift cell types...........32

9. Number of plastic particles per gram of sediment by site, size category and type ........41

\section{Conversion Factors}

U.S. customary units to International System of Units

\begin{tabular}{|c|c|c|}
\hline Multiply & By & To obtain \\
\hline \multicolumn{3}{|c|}{ Length } \\
\hline foot $(\mathrm{ft})$ & 0.3048 & meter $(\mathrm{m})$ \\
\hline \multicolumn{3}{|c|}{ International System of Units to U.S. customary units } \\
\hline Multiply & By & To obtain \\
\hline \multicolumn{3}{|c|}{ Length } \\
\hline micrometer $(\mu \mathrm{m})$ & 0.00003937 & inch (in.) \\
\hline centimeter $(\mathrm{cm})$ & 0.3937 & inch (in.) \\
\hline millimeter (mm) & 0.03937 & inch (in.) \\
\hline meter $(\mathrm{m})$ & 3.281 & foot $(\mathrm{ft})$ \\
\hline kilometer $(\mathrm{km})$ & 0.6214 & mile (mi) \\
\hline \multicolumn{3}{|c|}{ Mass } \\
\hline nanogram (ng) & 0.00000000003527 & ounce, avoirdupois (oz) \\
\hline milligram (mg) & 0.00003527 & ounce, avoirdupois (oz) \\
\hline $\operatorname{gram}(\mathrm{g})$ & 0.03527 & ounce, avoirdupois (oz) \\
\hline kilogram (kg) & 2.205 & pound avoirdupois (lb) \\
\hline
\end{tabular}

\section{Datums}

Horizontal coordinate information is referenced to the North American Datum of 1983 (NAD 83).

Tidal datum is referenced to Mean Lower Low Water (MLLW), which is the average of the lower low water height of each tidal day observed over the National Tidal Datum Epoch (NTDE), 1983-2001. 


\section{Abbreviations}

$\begin{array}{ll}\text { CDF } & \text { cumulative distribution function } \\ \text { Ecology } & \text { Washington State Department of Ecology } \\ \text { EPA } & \text { U.S. Environmental Protection Agency } \\ \text { GRTS } & \text { Generalized Random Tessellation Stratified } \\ \text { KCEL } & \text { King County Environmental Laboratory } \\ \text { MEL } & \text { Washington State Manchester Environmental Laboratory } \\ \text { MLLW } & \text { Mean Lower Low Water } \\ \text { NPDES } & \text { National Pollutant Discharge Elimination System } \\ \text { PAH } & \text { polycyclic aromatic hydrocarbon } \\ \text { PBDE } & \text { polybrominated diphenyl ether } \\ \text { PCB } & \text { polychlorinated biphenyl } \\ \text { PSEMP } & \text { Puget Sound Ecosystem Monitoring Program } \\ \text { OAPP } & \text { Quality Assurance Project Plan } \\ \text { RF } & \text { Random Forest } \\ \text { RSMP } & \text { Regional Stormwater Monitoring Program } \\ r^{2} & \text { amount of variation } \\ \text { SAM } & \text { Stormwater Action Monitoring } \\ \text { SWG } & \text { Stormwater Work Group of Puget Sound } \\ 2,3,7,8-T C D D T E O ~ & \text { 2,3,7,8-tetrachorodibenzo-p=dioxin } \\ \text { TEO } & \text { Toxicity EQuivalent concentration } \\ \text { TOC } & \text { total organic carbon } \\ \text { UGA } & \text { Urban Growth Area } \\ \text { USGS } & \text { U.S. Geological Survey }\end{array}$





\title{
Nearshore Sediment Monitoring for the Stormwater Action Monitoring (SAM) Program, Puget Sound, Western Washington
}

\author{
By Robert W. Black', Abby Barnes², Colin Elliot ${ }^{3}$, and Jennifer Lanksbury ${ }^{4}$
}

\section{Abstract}

Chemicals such as metals and organics (polychlorinated biphenyl [PCBs], polybrominated diphenyl ethers [PBDEs], polycyclic aromatic hydrocarbons [PAHs], and phthalates) continue to enter Puget Sound, western Washington, from point sources (such as industrial and municipal outfalls) and combined sewer outfalls and non-point sources (such as stormwater runoff). Runoff during storm events has been identified as a major source of contamination entering Puget Sound and has been implicated in the degradation of nearshore habitats and biota. Metals, organic chemicals, and other pollutants are known to accumulate in sediments such as those present along the shoreline of Puget Sound. In addition to chemical contaminants, small plastic particles (known as microplastics), found in marine waters of Puget Sound and suspected of being in aquatic sediments, are a potential concern because they can be ingested by animals and are suspected of transporting sorbed chemicals such as PCBs and metals.

The Stormwater Work Group of Puget Sound (SWG) (composed of State and municipal stormwater permittees, and other stakeholders) developed a strategy to address sediment conditions in the nearshore environment of Puget Sound. As part of this strategy, the SWG developed a regional stormwater monitoring strategy designed to inform monitoring requirements in National Pollutant Discharge Elimination System (NPDES) stormwater permits issued by the Washington State Department of Ecology (Ecology). The monitoring program is referred to as the Stormwater Action Monitoring (SAM).
The overall focus of the work described in this report is to address one of the goals of SAM, which is to characterize the status, spatial extent, and quality of Puget Sound sediment chemicals in the nearshore urban areas. The nearshore urban areas are defined as areas parallel to established Urban Growth Areas (UGAs) using a spatially balanced probabilistic Generalized Random Tessellation Stratified (GRTS) sampling design. One of the benefits of the GRTS sampling design used for this study is that it allows one to efficiently extrapolate from a relatively small number of sampled nearshore sites to the entire nearshore shoreline within the 2011 defined UGA boundaries of Puget Sound. In addition to characterizing nearshore sediment chemical concentrations, this study also characterized the abundance of microplastics in the nearshore sediment.

A total of 41 randomly selected sites were sampled throughout Puget Sound in summer and early autumn of 2016. All sampling sites were located at 6 feet below the Mean Lower Low Water line. The top 2-3 centimeters of sediment were collected using a boat-mounted, pre-cleaned stainless-steel box corer. All chemical samples were sieved to 2 millimeters and placed in appropriate containers for chemical analysis for PCBs, PBDEs, PAHs, phthalates, metals, total organic carbon, and grain size. Pre-sieved sediment samples were stored in glass containers for microplastic analysis. Nearshore sediment chemical concentrations were summarized using numerous statistical approaches to examine the minimum, mean, and maximum concentrations for each of the compounds analyzed and to compare the results to criteria and other nearshore and marine sediment studies.

\footnotetext{
${ }^{1}$ U.S. Geological Survey.

${ }^{2}$ Washington State Department of Natural Resources.

${ }^{3}$ King County Environmental Laboratory.

${ }^{4}$ Washington State Department of Fish and Wildlife.
} 
The GRTS sampling design also allowed the authors to assess the percentage of the UGA nearshore environment that did not meet established standards or criteria for each chemical analyzed. Additionally, regression and machine learning statistical analyses were used to examine relations between measured chemical concentrations, and land cover and geologic features at multiple scales within the watersheds adjacent to sampling sites. The influence of marine hydrodynamic factors on nearshore sediment chemical concentrations was statistically evaluated with nonparametric methods by assigning each sampling site to one of five nearshore drift cell types based on its location. The Puget Sound shoreline can be divided into segments, referred to as drift cells, based on the movement of sediment along the shore by waves. Each drift cell type has a unique influence on nearshore sediment transport.

The nearshore sediment chemical concentrations for organics and metals generally were low, and in most cases less than Washington State criteria. The concentrations of some PAHs were greater than the criteria, but these exceedances were limited to one or two sites. The results of the probabilistic study design determined that, for the PAHs examined, 96 percent or more of the 1,344 $\mathrm{km}$ of shoreline represented by this study had concentrations less than any established criteria. For the remaining organics (PCBs and PBDEs), the probabilistic study design indicates that more than 98 percent of shoreline examined had concentrations less than criteria or proposed standards. For the metals, the results of the study indicate that 100 percent of the nearshore sediment had concentrations less than the criteria. The relations between sediment organic and metal concentrations, and adjacent watershed land cover and the particle size of the samples, were determined to be weakly related. Although weakly related, the particle size of the sediment in a sample typically explained more of the variation in metal concentrations than organics. While the measured watershed attributes adjacent to the sampling sites and sediment size of the samples were weakly related to chemical concentrations, they were significantly related to unique drift cells along the shoreline of Puget Sound known as drift cells. Each drift cell represents a long-term directional transport of sediment from its source to its depositional zone. Sediment chemical concentrations were significantly higher in drift cells with limited sediment movement compared to those with higher sediment transport energy.

Microplastics in the nearshore sediment ranged from 0.02 to 0.65 pieces per gram of sediment, with a mean of 0.19 pieces per gram of sediment, and were dominated by small fibers (355-1,000 micrometers). Like chemical concentrations, microplastics concentrations in the nearshore sediment were poorly related to watershed land cover. Although not significantly different, microplastics concentrations generally were higher in the low energy drift cells compared to the high energy drift cells.
The results of this study provide a statistically valid status assessment of current nearshore sediment chemical conditions throughout Puget Sound in those areas adjacent to defined UGAs. In addition to the study findings of relatively low concentrations of PCBs, PBDEs, PAHs, phthalates, and metals, the study design provides a statistically valid tool for evaluating changes in these compounds over time if future nearshore sediment assessments are done. Furthermore, the assessment of microplastic abundance represents the first study of its kind that can be used as a benchmark for future evaluations. The results of this study will help inform Ecology in the implementation of monitoring requirements as part of its NPDES stormwater permitting process.

\section{Introduction}

The Puget Sound in western Washington represents a substantial economic, cultural, recreational, and aesthetic resource that has become the focus of a large-scale effort designed to restore biological resources and reduce levels of sediment and water contamination. The widespread use of many of the contaminants present in Puget Sound has been discontinued (that is, polychlorinated biphenyls [PCBs]); these contaminants are persistent and remain in the sediments and biota (Ross and others, 2000; West and others, 2001, 2008; Long and others, 2005; O'Neill and West, 2009; West, Lanksbury, and O'Neill, 2011; West and others, 2011). Chemicals such as metals and organics (polycyclic aromatic hydrocarbons [PAHs], polybrominated diphenyl ethers [PBDEs], phthalates, and PCBs) continue to enter Puget Sound from point sources (such as industrial and municipal outfalls) and combined sewer outfalls and non-point sources (such as air deposition, groundwater releases, and stormwater runoff) (Herrera Environmental Consultants, Inc., 2011; Hobbs and others, 2015; Milesi, 2015). PCBs are an organic chlorine compound that once was widely used as an insulator and coolant in electrical equipment such as transformers. When it was determined that PCBs were toxic and persistent in the environment, their use declined substantially. However, PCBs are still present in many fixtures and structures, and are still used in some sealants, caulks, adhesives, and other industrial products. PCBs are still of concern, given their persistence, and their reduced but continued use. PBDEs, are organobromine compounds used as flame retardants, but also are present in numerous industrial and building products. Like PCBs, PBDE also have toxic properties, and may have toxic effects on the liver, thyroid, and neurodevelopment, and the ability to disrupt hormone processes. PAHs are organic compounds present in coal and tar deposits, and also are produced by incomplete combustion of organic matter and fuels. They are associated with geographic areas with heavy use of creosote-treated wood, as well as with areas with 
extensive motor vehicle traffic. Although known to occur naturally (for example, as the result of forest fires), they typically are associated with anthropogenic activity. They are known to bioaccumulate in the tissues of algae, some invertebrates, and mollusks. They have been linked to different types of cancer, cardiovascular disease, and developmental effects. Phthalates are an organic compound primarily used as a plasticizer. Although used extensively in the past, they rapidly are being removed from products because of toxicity concerns. Some of these health concerns are related to endocrine disruption, endocannabinoid system disruption, and increased rates of obesity. Unlike PCBs, phthalates tend to rapidly degrade in the environment. Metals in marine sediment originate from multiple natural and anthropogenic sources. Excessive concentrations of each of these compounds can have toxic effects on plants and animals. The modes of toxicity vary for each compound.

Runoff during storm events has been identified as a major source of contamination entering Puget Sound, and has been implicated in the degradation of nearshore habitats and biota (Puget Sound Action Team, 2005). Many metals, organic chemicals, and other pollutants are known to preferentially partition in sediments such as those present along the shoreline of Puget Sound. More recently, small plastic particles, known as microplastics, also have been present in aquatic sediments (Andrady, 2011; Cole and others, 2011). Microplastics represent a potential concern because they can be ingested by animals (such as plankton, invertebrates, and fish) at many trophic levels and they affect feeding and digestive systems (Tourinho and others, 2010; Sussarellu and others, 2016) and transport sorbed chemicals such as PCBs and metals (Rios and others, 2007; Ashton and others, 2010). Systematic monitoring of nearshore sediments is needed to assess the status of nearshore sediment chemicals and pollutants and its relation to development, stormwater management, and related regulations (Hamel and others, 2015).

The Stormwater Work Group of Puget Sound (SWG) is a coalition of Federal, Tribal, State, and local governments; business, environmental, and agricultural entities; and academic researchers. All SWG members have interests and a stake in the Puget Sound watershed. The SWG was convened by Puget Sound municipal stormwater permittees, other stakeholders, and the Washington State Department of Ecology (Ecology) in October 2008 to develop a regional stormwater monitoring strategy and to recommend monitoring requirements in National Pollutant Discharge Elimination System (NPDES) stormwater permits issued by Ecology. In 2012, the SWG became the first "topical workgroup" included in the Puget Sound Ecosystem Monitoring Program (PSEMP), an organization that coordinates regional monitoring efforts to provide information supporting Puget Sound recovery efforts.

An overall strategy for monitoring and assessing the Puget Sound region was developed by the SWG in 2010 (Stormwater Work Group of Puget Sound, 2010). Based on discussions and recommendations of the working groups within the SWG, the stormwater effects on nearshore sediment study questions were identified (Stormwater Work Group of Puget Sound, 2010). By 2012, a monitoring program was framed with three categories for monitoring - (1) status and trends of receiving waters, (2) effectiveness monitoring of stormwater management practices, and (3) source identification studies. Sampling and studies in each of these categories occurred at set intervals based on the results from baseline studies such as the one presented here. As of July 1, 2017, this program is referred to as the Stormwater Action Monitoring (SAM; formally known as the Regional Stormwater Monitoring Program [RSMP]). This study was funded by pooled funds from municipal stormwater permittees to evaluate the status of nearshore sediments in urban areas of Puget Sound as one of several SAM receiving water studies. Additional information about other monitoring studies in the SAM is available at the SAM web page (https:// ecology.wa.gov/Regulations-Permits/Reporting-requirements/ Stormwater-monitoring/Stormwater-Action-Monitoring).

\section{Purpose and Scope}

The overall goal of the work described in this report is to characterize the status, spatial extent, and quality of Puget Sound sediment quality in the nearshore urban areas, defined as areas parallel to established Urban Growth Areas (UGAs). The U.S. Geological Survey (USGS), with help from the Washington State Department of Natural Resources and King County, conducted sampling and led the data analysis and report writing for this first round of nearshore sediment monitoring. SAM leveraged USGS expertise and a new microplastics laboratory to help refine the monitoring for subsequent monitoring rounds. The goals of this effort include:

- Assessment of the health of Puget Sound sediments in the nearshore urban areas, defined as areas inside nearshore areas parallel to established Urban Growth Areas (UGAs), as defined by the counties under Washington State law (Revised Code of Washington, section 36.70a.110);

- Identification of existing nearshore sediment quality problems and, where possible, provision of data to help target sources or sediment transport processes;

- Help in establishing protocols to document natural and human-caused changes over time in Puget Sound nearshore sediments;

- Support of nearshore research activities by making available uniformly collected, high-quality data; and

- Provision of nearshore data to assist the regulatory agencies in measuring the success of stormwater and other environmental management programs. 
The specific objectives of this nearshore sediment sampling are as follows:

- Collection of sediment data at randomly selected sites within the UGA sampling framework to evaluate the status of sediment chemistry,

- Quantitative assessment of the role of natural and anthropogenic factors in determining sediment quality, and

- Provision of scientifically based modification or updates to the sampling protocol and design for future monitoring activities.

This report does not include any results from unincorporated Pierce County. Pierce County chose to do their own monitoring as part of the SAM program.

A SAM study concurrent with this study was led by the Washington State Department of Fish and Wildlife to examine contamination concentrations in mussel tissue at most of the same sites (Lanksbury and others, 2017). The results from the mussel study are examined in collaboration with the sediment work to help address the goals described in this report.

\section{Methods}

A Quality Assurance Project Plan (QAPP) for this work was prepared and approved, and is available from the SAM web page (https://ecology.wa.gov/RegulationsPermits/Reporting-requirements/Stormwater-monitoring/ Stormwater-Action-Monitoring).

\section{Study Area}

The Puget Sound urban nearshore study area is part of the larger Salish Sea and covers a fjord-like marine estuary connected to the Pacific Ocean by the Strait of Juan de Fuca. Puget Sound geology and freshwater inputs from the many streams and rivers have a substantial influence on Puget Sound physical, chemical, and biological conditions. Monitoring for this nearshore sediment survey focused on a single management-related scale - the shoreline parallel to cities and established UGAs of Puget Sound. A shorelinesampling frame was defined to include the basins, channels, and embayments of Puget Sound, (1) from the United StatesCanada border to the southernmost bays and inlets near
Olympia and Shelton; (2) to Hood Canal; and (3) to parts of Admiralty Inlet, the San Juan Islands, and the eastern part of the Strait of Juan de Fuca (fig. 1).

\section{Site Selection}

The locations of the 2016 SAM nearshore sediment monitoring sites were selected using a probabilistic random stratified sampling design that targeted the land-based UGA boundaries of Puget Sound. This sampling framework was based on the spatially balanced, Generalized Random Tessellation Stratified (GRTS) multi-density survey design of the U.S. Environmental Protection Agency (EPA), and is described by Stevens (1997) and Stevens and Olsen (1999, 2003, 2004). One of the benefits of the GRTS method used for this study is that it allows one to efficiently extrapolate from a relatively small number of sampled nearshore sites or shoreline segments to the entire nearshore shoreline within the UGA boundaries (defined in 2011) of Puget Sound. Sitka Technology Group, LLC, using the GRTS design, generated a linear Puget Sound shoreline-sampling frame, and the result was 2,048 possible nearshore sites or shoreline segments in Puget Sound, each representing about $800 \mathrm{~m}$ of UGA shoreline. An identical approach was used to select sites for the SAM Status and Trends Mussel Monitoring study done at many of the same sites used for this study (Lanksbury and others, 2017).

The first 49 of the 2,048 possible sites were evaluated in two steps. First, a desktop analysis was done to see if any of the first 49 sites were unsuitable for sampling because of safety concerns, overrepresentation of a particular location, or locations heavily influenced by shipping and port activities. This analysis resulted in five sites $(9,32,34,39$, and 41 ) being eliminated from this study (table 1). Second, in summer 2016, field teams (consisting of USGS, King County, and Washington Department of Natural Resources) visited each site and sampled the site if it was suitable for sampling. If a site could not be sampled, owing to safety, sampling equipment limitations, and (or) the lack of sediment smaller than $2 \mathrm{~mm}$ in diameter, an attempt was made to sample the next randomly selected site. During summer 2016 sampling activities, three additional sites $(5,8$, and 10$)$ where determined to be unsuitable for sampling owing to the lack of sediment smaller than $2 \mathrm{~mm}$ in diameter (table 1). This process was done until a total of 41 sites were sampled (fig. 2). Of these 41 sites, 31 sites also were mussel sampling sites (Lanksbury and others, 2017) (table 1). 


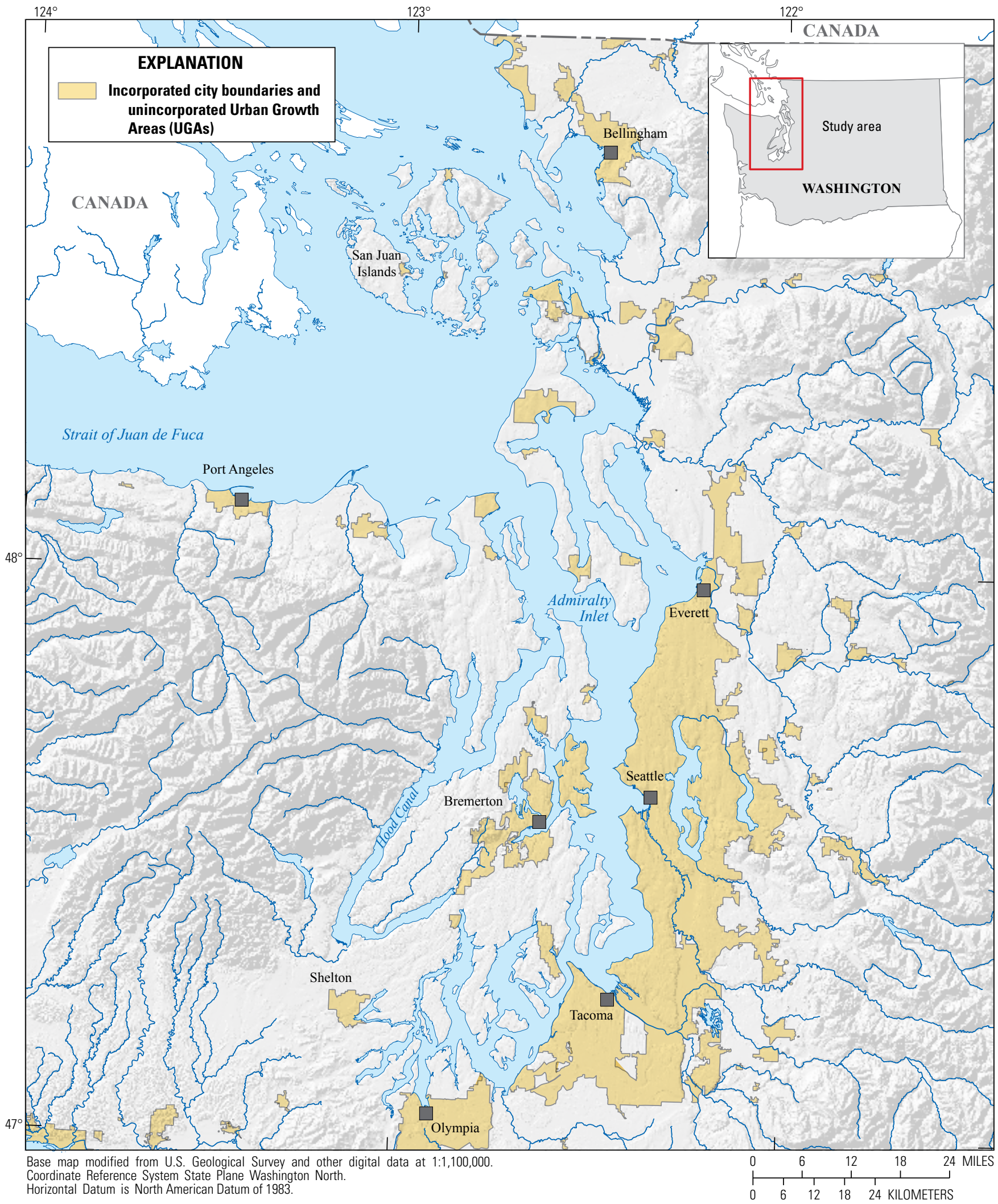

Figure 1. Puget Sound urban nearshore study area, Puget Sound, western Washington. 
Table 1. Sites sampled as part of the Stormwater Action Monitoring Nearshore Sediment Status and Trends sampling, Puget Sound, western Washington.

[See figure 2 for locations of non-excluded sites sampled. Site No: Represents the order in which the site was selected from all possible sites. SAM mussel sampling site: Stormwater Action Monitoring mussel sampling site. Within incorporated UGA?: Within incorporated Urban Growth Area? Reason for exclusion: RSMP, Regional Stormwater Monitoring Program; -, no data]

\begin{tabular}{|c|c|c|c|c|c|c|}
\hline $\begin{array}{l}\text { Site } \\
\text { No. }\end{array}$ & Latitude & Longitude & County & $\begin{array}{l}\text { SAM } \\
\text { mussel } \\
\text { sampling } \\
\text { site }\end{array}$ & $\begin{array}{l}\text { Within } \\
\text { incorporated } \\
\text { UGA? }\end{array}$ & Reason for exclusion \\
\hline 1 & 47.048 & -122.907 & Thurston & No & Yes & - \\
\hline 2 & 47.501 & -122.386 & King & Yes & Yes & - \\
\hline 3 & 47.682 & -122.504 & Kitsap & Yes & Yes & - \\
\hline 6 & 47.619 & -122.525 & Kitsap & Yes & Yes & - \\
\hline 7 & 47.647 & -122.426 & King & No & Yes & - \\
\hline 18 & 48.049 & -122.777 & Jefferson & Yes & No & Sample damaged. \\
\hline 19 & 47.255 & -122.376 & Pierce & No & Yes & $\begin{array}{l}\text { Site excluded after discussion with RSMP manger owing to } \\
\text { oversampling of the Blair Waterway. Three sites in close } \\
\text { proximity in the Blair Waterway do not align with the intent of } \\
\text { the study design. }\end{array}$ \\
\hline 12 & 48.296 & -122.580 & Island & No & Yes & - \\
\hline 13 & 47.293 & -122.494 & Pierce & Yes & Yes & - \\
\hline 14 & 47.571 & -122.606 & Kitsap & Yes & Yes & - \\
\hline 15 & 48.494 & -122.679 & Skagit & Yes & Yes & - \\
\hline 16 & 47.854 & -122.337 & Snohomish & Yes & Yes & - \\
\hline 17 & 47.069 & -122.919 & Thurston & Yes & Yes & - \\
\hline 18 & 47.463 & -122.371 & King & Yes & Yes & - \\
\hline 19 & 47.661 & -122.497 & Kitsap & Yes & Yes & - \\
\hline 20 & 48.118 & -123.417 & Clallam & No & Yes & - \\
\hline 21 & 47.305 & -122.513 & Pierce & Yes & Yes & - \\
\hline 22 & 47.559 & -122.598 & Kitsap & Yes & Yes & - \\
\hline 31 & 48.693 & -122.907 & San Juan & Yes & No & - \\
\hline 132 & 47.975 & -122.227 & Snohomish & No & Yes & Port of Everett remediaton activity. \\
\hline 33 & 47.111 & -122.707 & Pierce & No & Yes & - \\
\hline 134 & 47.587 & -122.353 & King & Yes & Yes & $\begin{array}{l}\text { Located well within Port of Seattle shipping activity. Rejected } \\
\text { owing to safety and heavily altered environment. }\end{array}$ \\
\hline 35 & 47.665 & -122.568 & Kitsap & Yes & Yes & - \\
\hline 36 & 48.142 & -123.427 & Clallam & No & Yes & - \\
\hline 37 & 47.170 & -122.612 & Pierce & Yes & Yes & - \\
\hline 38 & 47.598 & -122.671 & Kitsap & Yes & No & - \\
\hline 139 & 47.631 & -122.381 & King & Yes & Yes & $\begin{array}{l}\text { Located well within Port of Seattle shipping activity. Rejected } \\
\text { owing to safety and heavily altered environment. }\end{array}$ \\
\hline
\end{tabular}


Table 1. Sites sampled as part of the Stormwater Action Monitoring Nearshore Sediment Status and Trends sampling, Puget Sound, western Washington.-Continued

\begin{tabular}{|c|c|c|c|c|c|c|}
\hline $\begin{array}{l}\text { Site } \\
\text { No. }\end{array}$ & Latitude & Longitude & County & $\begin{array}{l}\text { SAM } \\
\text { mussel } \\
\text { sampling } \\
\text { site }\end{array}$ & $\begin{array}{l}\text { Within } \\
\text { incorporated } \\
\text { UGA? }\end{array}$ & Reason for exclusion \\
\hline 40 & 48.133 & -122.762 & Jefferson & No & Yes & - \\
\hline${ }^{1} 41$ & 47.269 & -122.402 & Pierce & No & Yes & $\begin{array}{l}\text { Site excluded after discussion with RSMP manger owing to } \\
\text { oversampling of the Blair Waterway. Three sites in close } \\
\text { proximity in the Blair Waterway do not align with the intent of } \\
\text { the study design. }\end{array}$ \\
\hline 42 & 47.574 & -122.626 & Kitsap & Yes & Yes & - \\
\hline 43 & 48.521 & -122.616 & Skagit & Yes & Yes & - \\
\hline 44 & 48.038 & -122.398 & Island & No & Yes & - \\
\hline 45 & 47.429 & -122.352 & King & No & Yes & - \\
\hline 46 & 47.788 & -122.493 & Kitsap & No & No & - \\
\hline
\end{tabular}

${ }^{1}$ Indicates a site excluded from the final list of sites and the reason for exclusion.

\section{Sediment Collection}

All sediment sampling was done from August 8 to October 5, 2016. At each of the 41 locations sampled, personnel on a research vessel collected nearshore marine sediment $6 \mathrm{ft}$ below the Mean Lower Low Water (MLLW) line perpendicular to the shoreline using a pre-cleaned stainlesssteel box corer. All locations and depths were verified with a Global Positioning System and depth sounding equipment, respectively. The top $2-3 \mathrm{~cm}$ of material were removed from the corer, sieved to less than $2 \mathrm{~mm}$, and placed in appropriate containers for chemical analysis. A more detailed description of the sediment sampling methods is available in the study QAPP (https://ecology.wa.gov/RegulationsPermits/Reporting-requirements/Stormwater-monitoring/ Stormwater-Action-Monitoring).

\section{Chemical Analyses}

The sediment samples from each site were analyzed for the following constituents:

- Grain size (on the $<2$-mm sample),

- Total organic carbon (TOC),

- 209 PCB congeners,

- 48 PBDE congeners (appendix 1),
- 42 PAHs (appendix 1),

- 6 phthalates (appendix 1), and

- 11 metals (appendix 1).

Grain size, TOC, metals, PAHs, and phthalates were analyzed at the Washington State Manchester Environmental Laboratory (MEL) and King County Environmental Laboratory (KCEL). The PCBs and PBDEs were analyzed at SGS AXYS (Sidney, British Columbia). Many PCB congeners cannot be analytically separated during laboratory analyses and are reported as a mixture of specific congeners. This resulted in a total of 159 unique individual $\mathrm{PCB}$ congeners or congener mixtures. To measure the amount of variability in the compositing of sediment in the field, field-splits were collected for all constituents at four randomly selected sites and submitted as blind replicates. In addition to the field-splits, an inter-laboratory comparison between the MEL and KCEL laboratories for $\mathrm{PAH} / \mathrm{phthalates}$ and metals was done for samples collected at 10 of the 41 sites. All laboratory results used in the data analysis were reviewed by the EPA-approved Washington State Manchester Environmental Laboratory, King County Environmental Laboratory, and Washington Water Science Center USGS scientists. Access to all laboratory results and inter-laboratory results is available at https:// ecology.wa.gov/Regulations-Permits/Reporting-requirements/ Stormwater-monitoring/Stormwater-Action-Monitoring. 


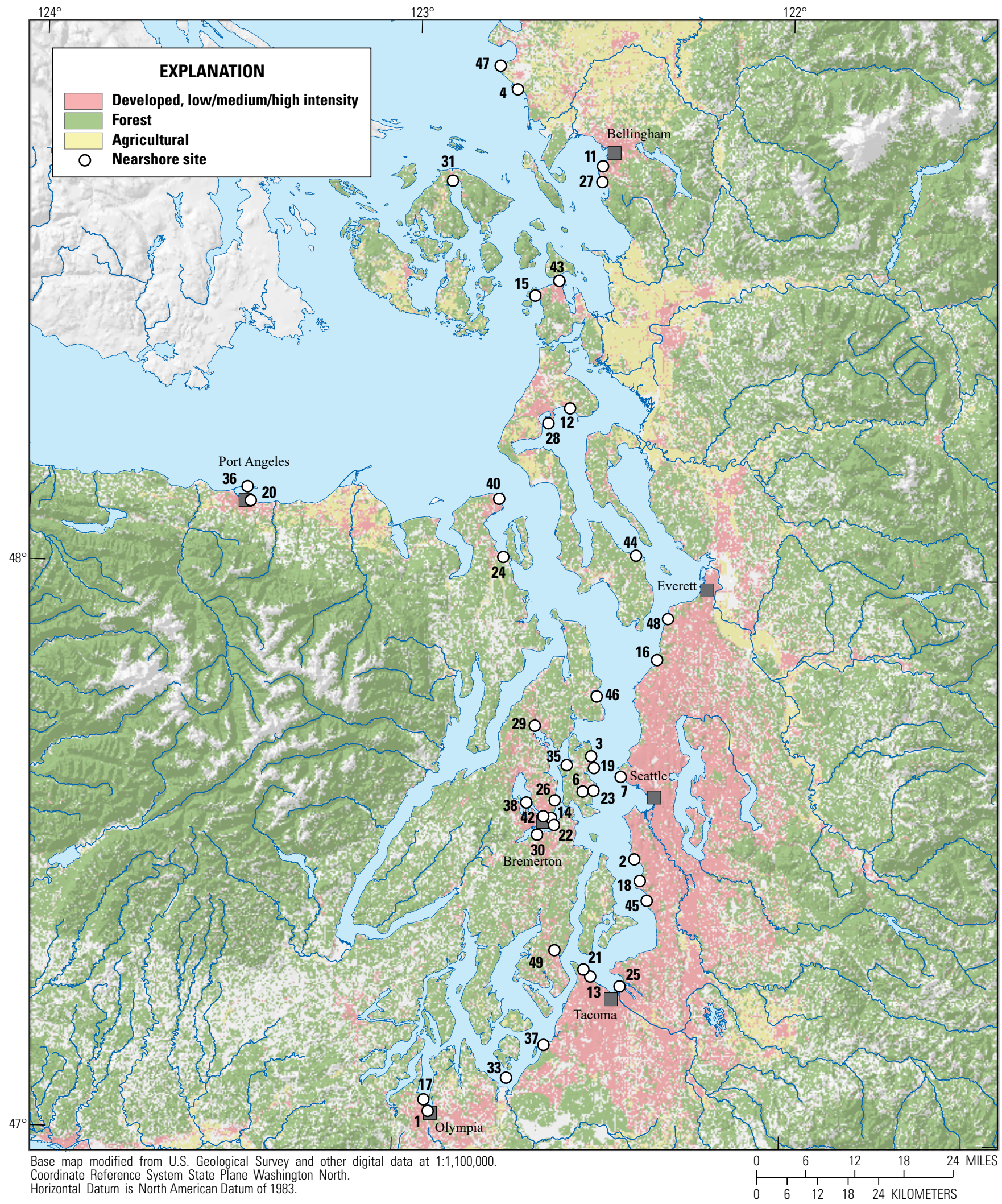

Figure 2. Sampling site locations, Puget Sound urban nearshore study area, Puget Sound, western Washington. See table 1 for more details on sites sampled. 


\section{Microplastics Approach}

USGS scientists collected additional sediment samples while in the field at the SAM nearshore sediment sites to pilot a microplastic extraction and enumeration method in the USGS Washington Water Science Center laboratory. As of 2018, field and laboratory protocols for characterizing microplastics in sediment are experimental; State and federally approved standard do not exist. USGS funded this pilot-like microplastics analysis to help refine laboratory methods and establish a preliminary status of plastics in the nearshore environment of Puget Sound.

All sediment samples were collected at the same time and used the same collection methods as those used for chemical analyses, and are described in the project QAPP. Samples were placed in glass jars with foil-lined lids. Prior to removing plastics from the sediment, each sample was homogenized with a clean stainless-steel spoon, and a weighed portion of the sample was removed for analysis. Each sample was processed using the extraction method described in National Oceanic and Atmospheric Administration (2016). During the extraction process, retained plastics were sieved into particles larger than $1,000 \mu \mathrm{m}$, and those from 355 to $1,000 \mu \mathrm{m}$. For each sample, plastics were counted in each size class and characterized as either a fiber or non-fiber (beads, films, foam, fragments, or line). Results were expressed as numbers of plastic particles per gram of sediment.

\section{Analysis Approach}

A series of analytical approaches were used to meet the study objectives. The analytical approaches were designed to summarize the following:

1. The sediment bound chemical concentrations,

2. The relation between chemical concentrations and potential land-cover explanatory variables,

3. The effects of nearshore hydrodynamic activity on chemical concentrations,

4. The abundance of microplastics in nearshore sediment, and

5. The extrapolation of the sediment chemical concentrations from this study to the regional Puget Sound urban nearshore scale.

\section{Summary Statistics for Chemicals}

The first approach was to provide a summary of the range and mean concentrations of the chemicals analyzed, as well as the percentage of sites in which a chemical was detected. To calculate the summary statistics, the R statistical system was used (R Development Core Team, 2006). Results reported as not detected by the laboratories, often referred to as censored data, are contained in the datasets used in this study and are reported as a value less than the detection limit at which they were assessed. These values do not indicate a concentration of zero, but have unknown concentrations less than the detection limit. These values present a problem when summarizing a series of data for a particular chemical that contains censored values. Historically, these values either were excluded during data analysis or were assigned a value, often one-half of the detection limit. As noted in Helsel (2005), excluding or using an assigned value often can generate invalid or misleading summaries of data. In this study, for chemicals with censored values, the nonparametric KaplanMeier method was used to generate summary statistics when less than one-half of the values were censored and the robust Regression on Order Statistics was used if 50-80 percent of the values were censored. Both methods effectively generate summary statistics that minimize the potential bias that can be created by excluding or assigning a value to censored data (Helsel, 2005).

In addition to the summary statistics for the original chemical concentrations determined in the laboratory, concentrations for total PCBs, PBDEs and PAHs also were summarized. Total PCBs and PBDEs were determined by the sum of all the detected PCB or PBDE congener concentrations. Total PAHs was the sum of all the detected PAH concentrations. TOC-normalized values of the organic chemicals (PCBs, PBDEs, PAHs, and phthalates) also were summarized. TOC-normalized concentrations of organic pollutants often are presented because the toxicity of these chemicals is well correlated with the percentage of organic carbon in a sediment sample (Roy and Griffin, 1985; DiToro and others, 1991). A similar correlation typically is not observed with the original laboratory concentrations. Organic chemicals are known to preferentially partition into the organic material in sediment, whereas metals are not known to do this. To create a TOC-normalized concentration, the original concentration is divided by the percentage of TOC expressed as a decimal. The TOC values by site are presented in appendix 2. TOC values in the marine environment can 
vary greatly and range from less than 0.1 percent to more than 15 percent (Michelsen, 1992). For this study, sediment TOC values ranged from a low of 0.05 percent to a high of 7.75 percent, with a mean of 0.68 percent. Because of the wide range in TOC values from site to site, sediment chemical concentrations normalized by very low or very high TOC values can result in large changes in chemical concentrations when compared to their original values.

When available, sediment chemical concentrations were compared to established Washington State marine sediment criteria or proposed target concentrations. Comparisons to TOC-normalized criteria were avoided when possible given the large range in the TOC percentages measured in this study, which can substantially affect TOC-normalized data.

\section{Extrapolating Sediment Chemical Concentration Results to the Puget Sound Urban Nearshore Scale}

To efficiently extrapolate from a relatively small number of nearshore sites to the entire population of nearshore sample sites, a statistically based spatially balanced study approach known as the Generalized Random Tessellation Stratified (GRTS) design was used (Stevens and Olsen, 2004; Cusimano and others, 2006; Larsen and others, 2008; Roper and others, 2010; Olsen and others, 2012). Because the nearshore study was spatially balanced and probabilistic, it is possible to extrapolate the observed sediment chemical concentrations at the sampling sites to the entire nearshore list of sampling sites. Before this can be done, the spatial weight given to each site must be adjusted based on the number of sites sampled as well as the number of sites rejected. As noted in section, "Site Selection," each of the 2,048 potential nearshore sites represented about $800 \mathrm{~m}$ of UGA shoreline. In accordance with the probabilistic GRTS protocol, 49 sites were visited in the random order in which they were identified, until 41 sites were sampled. Eight sites were removed from sampling consideration (table 1). The final spatial weight for each site was adjusted based on the total number of sites sampled and the number of sites removed using the "spsurvey" analysis package in the statistical package R (Kincaid and Olsen, 2013). The spatial weight adjustment resulted in each sample site representing about $32 \mathrm{~km}$ of UGA shoreline (excluding unincorporated Pierce County). The design of the GRTS approach allows one to generate cumulative distribution function (CDF) plots to evaluate the percentage of the target population shoreline that is less than or equal to each possible value of a particular chemical concentration (Stoddard and others, 2005; Merritt and Hartman, 2012; Kincaid and Olsen, 2013). The R package "spsurvey" (Kincaid and Olsen, 2013) was used to generate CDF plots for all chemical concentrations.
A CDF plot for a particular chemical sampled using a GRTS design establishes a baseline with which future surveys (using the same probabilistic design) can be compared as a means of assessing trends. Such an approach represents a potentially more accurate method for evaluating the regional scale trend of sediment quality than using traditional measures of central tendency such as the mean or median value of a particular chemical concentration of sampled sites. Depending on the expected response of a particular chemical to environmental stressors or to restoration measures, the CDF would be expected to shift to the left (that is, lower concentrations dominate the distribution) or right (that is, higher concentrations dominate the distribution). Confidence intervals for each CDF provide a statistical basis for assessing significant changes.

\section{Effects of Land Cover and Geologic Features on Sediment Quality}

To evaluate the role of land-cover and geologic features on nearshore sediment chemical concentrations, two different scales were analyzed:

1. Watershed land cover (that is, nearshore adjacent watersheds), and

2. Shoreline land cover (that is, within $200 \mathrm{~m}$ of the shoreline).

These approaches are identical to those used by the SAM Status and Trends Mussel Monitoring study (Lanksbury and others, 2017).

Watershed Land Cover-To characterize land cover on a watershed scale adjacent to each nearshore sediment site, land-cover data from the National Land Cover Dataset (Homer and others, 2015) were overlaid onto predefined, watershed catchment areas adjacent to the Puget Sound shoreline. These localized watershed catchment areas originally were developed by Ecology for another purpose (Stanley and others, 2016), but were determined to be of a size and location appropriate for use in this study (median area of $8.8 \mathrm{~km}^{2}$ ) because of their proximity to and hypothesized direct influence on the nearshore environment. For each watershed, we characterized the percentage of land area covered by urbanization, forest, agriculture, and wetlands; and the average value (that is, intensity in percent) of impervious surfaces and road density within each watershed to investigate the influence of each of these attributes on nearshore sediment contamination (appendix 3).

Shoreline Land Use and Geologic Classes-In contrast to the analysis using the localized watersheds, the effect of land use at a smaller nearshore scale also was used. The percentage of land area covered by urbanization, forest, and 
agriculture within $200 \mathrm{~m}(656 \mathrm{ft})$ of the shoreline adjacent to each sediment site was calculated, as well as the Geologic Class using data from the National Oceanic and Atmospheric Administration C-CAP Land Cover Atlas (https://coast. noaa.gov/digitalcoast/tools/lca.html, accessed January 10, 2018), which reports land use related to discrete shoreline segments (appendix 3). The C-CAP shoreline segments are a modification of the Salmon and Steelhead Habitat Inventory and Assessment Project "GeoUnit" attribute, which used the Washington Department of Natural Resources ShoreZone and various other sources and methods to develop the segments (McBride and others, 2009).

Two statistical techniques were used to evaluate the relation between these land-cover and geologic attributes on sediment chemistry concentrations. These included linear regression and an ensemble learning method known as Random Forest (RF) regression. To determine if watershed land-cover, shoreline land-cover, or geologic features of the watershed adjacent to the nearshore sediment sampling sites were statistically related to the concentrations of the chemicals present at each site, stepwise linear regression and RF analysis were used for each compound of interest (Sokal and Rohlf, 1981; Prasad and others, 2006; Cutler and others, 2007). A forward stepwise linear regression method was used to fit regression models to each of the chemicals without censored values, in which the selection of land-cover and (or) geologic predictive variables was carried out by an automatic procedure that resulted in significant overall models $(p=0.05)$ and significant parameter estimates for the selected predictor variables. All concentration values were natural $\log$ transformed prior to the regression analyses to meet the normality assumption of regression (Sokal and Rohlf, 1981).

$\mathrm{RF}$ analysis is an alternative to multiple regression that can be used to examine nonlinear relations between a particular dependent variable (such as a chemical concentration) and various explanatory variables (such as various land-cover features within a watershed adjacent to a sampling site). RF is a type of regression tree analysis that does not rely on assumptions about the relation between response and predictor variables and allows for interactions and nonlinearities among variables. RF methods have numerous benefits over other regression tree methods. First, RF methods enhance predictive abilities while limiting overfitting. Second, RF can model complex interactions among predictor variables. For example, when predictor variables are highly correlated but good predictors of response variable, traditional stepwise and criterion-based variable selection procedures typically will retain only one or two of the correlated variables and discard the rest. RF procedures distribute the importance of the correlated predictor variables and guard against eliminating predictor variables that may be important, but are correlated with other predictors (Cutler and others, 2007). Finally, RF has a robust approach to characterizing the relative importance of predictor variables; the most important predictors will have the largest decrease in model predictability (that is, explanation power) when they are removed from the model. The RF method also identifies the percentage of variance explained for each model. The RF procedure was done using the $\mathrm{R}$ statistical system (Liaw and Wiener, 2002; R Development Core Team, 2006).

\section{Effects of Marine Hydrodynamics on Sediment Quality}

The Puget Sound shoreline can be divided into segments, referred to as drift cells, based on the movement of sediment along the shore by waves, tides, and winds (Johannessen and MacLennan, 2007; Simenstad and others, 2011). Drift cells can range from $50-100 \mathrm{~m}$ to about $65 \mathrm{~km}$ in length, and are essentially compartments within which sediment transport is confined and that are relatively independent of each other. Each cell includes three main parts:

1. Source(s) of beach material,

2. A transport zone, and

3. Area(s) where materials are deposited.

Each of these drift cells has a substantial influence on the formation and maintenance of shorelines throughout Puget Sound. The Ecology Coastal Atlas Map (https://fortress. wa.gov/ecy/coastalatlas/tools/Map.aspx) characterizes the coast of Puget Sound in terms of one of five drift cell types:

1. Divergence Zone - A segment of erosional shoreline where net shore drift can be in either direction. A divergent zone is the common origin of two drift cells with net shore drift in opposite directions.

2. Right to Left - The net shore drift moves from right to left as you look at the shoreline from the water.

3. Left to Right-The net shore drift moves from left to right as you look at the shoreline from the water.

4. No Appreciable Drift-No significant net shore drift owing to limited sediment supply (a rocky shoreline, for example), very low wave energy (in marshes or small estuaries), or a shoreline where artificial fill and other modifications extend into deep water.

5. Undefined-No drift cell information available for this location.

For this study, each SAM nearshore sediment site was defined as being in one of these 5 drift cells (appendix 3). For each chemical compound of interest, concentrations for sites within each of these drift cells were statistically compared. 
The sediment concentrations of total PCBs, total of the 12 most toxic PCB congeners, total PBDEs, total PAHs, and those PAHs and metals with State criteria were each individually compared across each of the five drift cell categories using the nonparametric Kruskal-Wallis test. If a statistically significant difference between drift cells occurred for a particular compound, a Conover-Inman post-hoc pairwise comparison test was done to determine which of the five drift cells were significantly different from one another. For those compounds with censored values, a modified Kruskal-Wallis test as described in Helsel (2005) was used. The R statistical system was used for these analyses (R Development Core Team, 2006).

\section{Comparison with Mussel and Other Sediment Results}

Although the SAM 2015-16 Mussel Monitoring Survey (Lanksbury and others, 2017) was not done at the same time as the nearshore sediment sampling (6 months difference), Thirty-one of the 41 sediment sites were collocated with the mussel sampling sites. Chemical results for the collocated sediment and mussel sites were graphically compared to examine relations between the two media and to examine the potential benefit of sampling both media simultaneously. Additionally, the sediment samples collected as part of this study were compared to all marine sediment sampling results of the (PSEMP) during 2002-14 (Dutch and others, 2009; Environmental Information Management System data, accessed August 2017, at https://fortress.wa.gov/ ecy/eimreporting/). To place the SAM nearshore sediment results in context with another Washington State marine sediment collection effort, with documented methods and data contained in a publicly accessible database, simple tabular and graphical comparisons were made between these two study results for those compounds common to both programs. Although both the SAM and PSEMP projects sampled Puget Sound marine sediments, PSEMP used different collection methods, locations, and sampling time of year. For example, PSEMP collected samples primarily in June, did not field sieve their samples, and collected deeper samples. Given these differences, no effort was made to do any statistical comparisons; instead, comparisons were limited to tabular and graphical methods.

\section{Microplastics}

The analysis of the microplastics results used the same statistical approaches described in section, "Summary Statistics for Chemicals." Analyses were done on total number of plastic pieces per gram of dry sediment collected at each site. These values also were characterized by their shape (fibers or non-fibers) and size categories (355-1,000 $\mu \mathrm{m}$ and $>1,000 \mu \mathrm{m})$.

\section{Results of Puget Sound Nearshore Monitoring}

The nearshore sediment chemical concentration results summarized across the probabilistically selected sites to describe the UGA shoreline identified for the SAM nearshore study generally indicated low concentrations of organic contaminants and moderate-to-low concentrations of metals. Although concentrations of some of the PAHs were greater than the Washington State marine sediment criterion, we determined that, for all chemicals examined, 96 percent or more of the $1,344 \mathrm{~km}$ of shoreline represented by the study were had concentrations less than any established criteria.

\section{Polychlorinated Biphenyl Concentrations and Extrapolation to the Stormwater Action Monitoring Nearshore}

For this study, each sample was analyzed for 209 PCB variations, known as congeners. At least 1 of the 209 potential PCB congeners was present at all sites sampled for this study. The percentage of PCB congeners detected varied from site to site (fig. $3 A$ ). For example, about 21 percent of the 209 congeners were present at one site, whereas about 94 percent of the congeners were present at another site. The mean number of congeners detected across all sites was about 67 percent.

The mean concentration of total PCBs for the nontransformed values was $11.4 \mathrm{ng} / \mathrm{g}$, with a minimum concentration of $0.016 \mathrm{ng} / \mathrm{g}$ and a maximum concentration of $359.1 \mathrm{ng} / \mathrm{g}$ (fig. 3B). The mean TOC-normalized total PCB concentration was $1,618 \mathrm{ng} / \mathrm{g}$ with a minimum of $10 \mathrm{ng} / \mathrm{g}$ and a maximum of 40,344 ng/g. As of 2018, there are no Washington State criteria for total PCBs in marine sediment based on summing congeners. However, the EPA 2014 Record of Decision for the Lower Duwamish Waterway Superfund Site cleanup identified tidally influenced total PCB sediment concentrations to achieve specific clean-up goals (U.S. Environmental Protection Agency, 2014). Two of these clean-up concentration goals are presented in figure $3 B$. The first goal of $1,300 \mathrm{ng} / \mathrm{g}$ (human contact) is to reduce risks from direct contact (skin contact and incidental ingestion) to contaminated sediments during net fishing, clamming, and beach play to protect human health. None of the nearshore sediment samples exceeded this concentration. A second concentration goal of $128 \mathrm{ng} / \mathrm{g}$ (river otter) is to reduce PCBs to concentrations that primarily protect river otter that rely on organisms that are exposed to contaminated sediment for food. Only one site exceeded this concentration. 

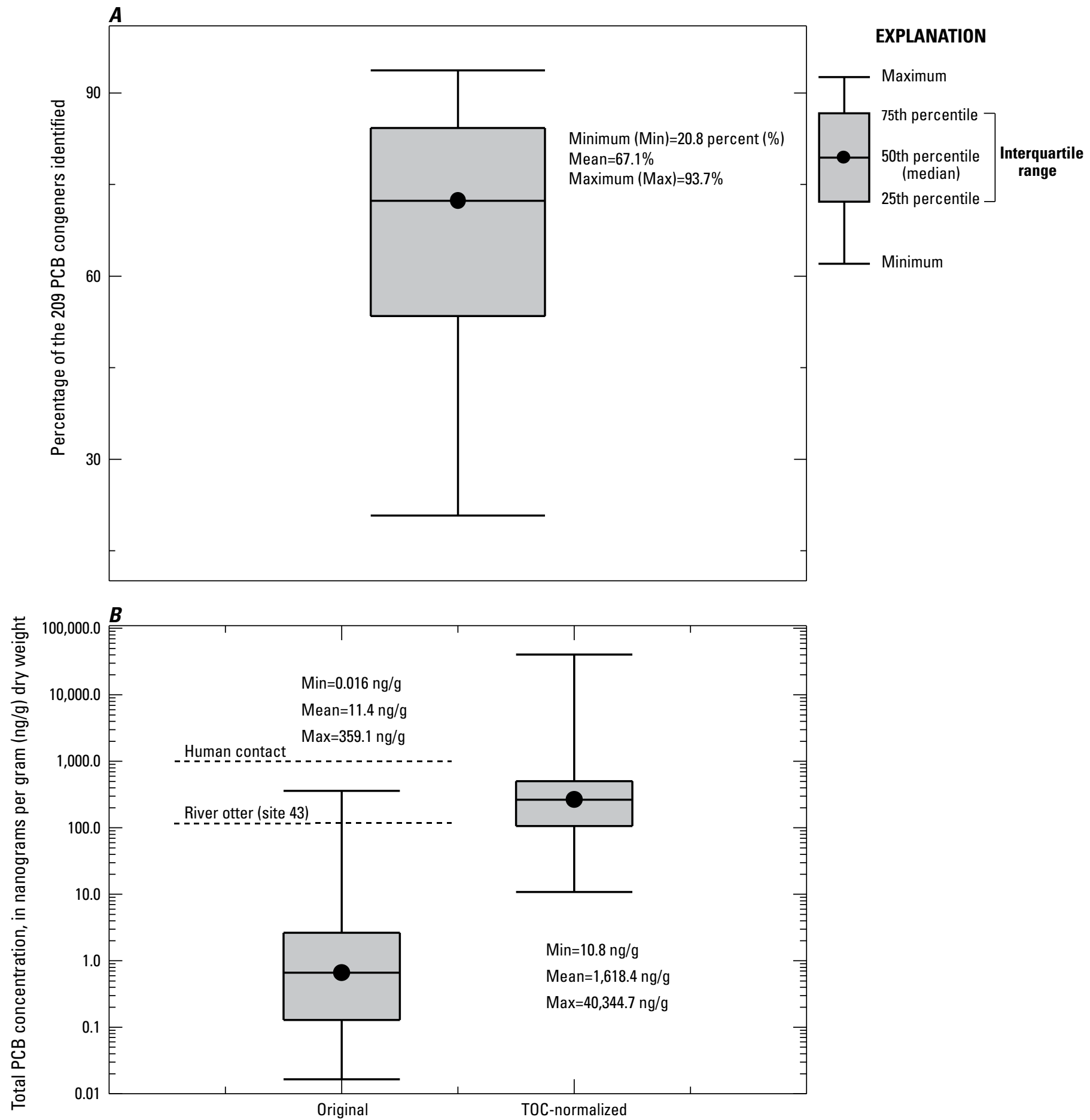

Original concentration or total organic carbon (TOC)-normalized

Figure 3. Percentage of the 209 polychlorinated biphenyl (PCB) congeners $(A)$, and total and total organic carbon-normalized total PCB concentrations $(B)$, detected at the 41 nearshore sediment sites, Puget Sound, western Washington. Only those congeners with concentrations greater than detection limits were included in total concentrations. 
Of the 209 PCB congeners, 12 have been identified as being the most toxic (Van den Berg and others, 2006) - 77, $81,105,114,118,123,126,169,156,157,167$, and 189. The percentage of these 12 toxic PCB congeners detected is presented in figure $4 A$. Detections ranged from about 9 percent ( 1 of the 12 congeners) at one of the sites to as high as about 91 percent (11 of the 12 congeners) at the other sites. The mean detection rate was greater than 69 percent. The mean concentration for the total of the 12 most toxic PCB congeners was $0.8 \mathrm{ng} / \mathrm{g}$ for the non-normalized values, with a minimum of less than 0.01 and a maximum of $23.2 \mathrm{ng} / \mathrm{g}$ (fig. 4B). The mean TOC-normalized value was about $124 \mathrm{ng} / \mathrm{g}$ and ranged from about 0.2 to $2,613 \mathrm{ng} / \mathrm{g}$.

The 12 toxic PCB congeners can be mathematically adjusted to represent their toxicity in terms of 2,3,7,8-tetrachorodibenzo- $p$-dioxin (2,3,7,8-TCDD). This adjustment produces a value known as a Toxicity EQuivalent concentration (TEQ) of 2,3,7,8-TCDD. The mean TEQ was $0.11 \mathrm{mg} / \mathrm{kg}$, with a minimum of less than 0.01 and a maximum of $1.74 \mathrm{mg} / \mathrm{kg}$ (fig. 5). The TEQ of 2,3,7,8-TCDD in SAM urban nearshore sediments was much less than the proposed standard of $6.7 \mathrm{mg} / \mathrm{kg}$ (Narquis and others, 2008).

The GRTS design used for this study allows one to extrapolate from the measured sediment chemistry concentrations to the entire SAM nearshore UGA shoreline of about 1,344 km. CDF plots for each chemical describe the percentage of nearshore UGA shoreline that is less than or equal to a specific concentration. The CDF plots for the totals of 209 PCB congeners and the 12 most toxics PCB congeners are shown as a Toxicity EQuivalent concentration (TEQ) in figure 6. The plot for total PCBs indicates that more than 98 percent of the potential Puget Sound UGA nearshore shoreline $(1,344 \mathrm{~km})$ has concentrations of less than $128 \mathrm{ng} / \mathrm{g}$, the proposed criterion suggested as a concentration suitable for protecting organisms that feed on organisms living in sediments. Based on the total PCB CDF plot, 100 percent of the nearshore sediment has total PCB concentrations less than any of the PCB criteria described earlier in this section. The TEQ concentration of the 12 most toxic PCBs suggests that 100 percent of the nearshore UGA shoreline has concentrations equal to or less than the proposed $6.7 \mathrm{mg} /$ $\mathrm{kg}$ standard. There is no Washington State marine sediment criterion for TEQ-PCBs. However, a standard of $6.7 \mathrm{mg}$ / $\mathrm{kg}$ has been suggested in the literature (Narquis and others, 2008). The CDF plot in figure 6 indicates that 100 percent of the UGA nearshore sediment has TEQ-PCB concentrations less than this proposed standard. The maximum concentrations for total PCBs and TEQ-PCBs at 25, 50 and 75 percent of 1,344-km nearshore UGA shoreline examined in this study are shown in table 2.

\section{Polybrominated Diphenyl Ether Concentrations and Extrapolation to the Stormwater Action Monitoring Nearshore}

PBDEs have 209 potential congeners. For this study, 48 of the 209 congeners were characterized. At least 1 of the 48 PBDE congeners was present at all the sites sampled. As of 2018, Washington State does not have a total sediment criterion for PBDEs. The detection percentages of the 48 PBDE congeners ranged from about 14 percent to more than 83 percent, with a mean of about 45 percent (fig. $7 A$ ). As with PCBs, the concentrations of all PBDE congeners characterized for this study were totaled for each site and also were TOCnormalized (appendix 2). The mean concentration for the nonnormalized or original values for total PBDEs was $0.69 \mathrm{ng} / \mathrm{g}$, with a minimum of 0.001 and a maximum of $4.28 \mathrm{ng} / \mathrm{g}$ (fig. 7B). The mean TOC-normalized concentration for total PBDEs was $118.5 \mathrm{ng} / \mathrm{g}$, with a range of $1.30-1,156.6 \mathrm{ng} / \mathrm{g}$.

A CDF plot of total PBDEs, showing the percentage of the 1,344-km UGA nearshore less than or equal to specific concentrations, is presented in figure 8. Unlike the PCB curves, the total PBDE plot suggests a greater range in potential concentrations with greater uncertainty, given the wider 95-percent confidence intervals. There is no Washington State marine sediment criterion for total PBDEs, but the CDF plots can be used to examine the proportions of UGA shoreline that currently are equal to or less than various concentrations (table 2), and can be used to statistically evaluate changes in concentration over time.

\section{Polycyclic Aromatic Hydrocarbon Concentrations and Extrapolation to the Stormwater Action Monitoring Nearshore}

Nearshore sediments were analyzed for 42 different PAHs in this study. At least 1 of these 42 PAHs was detected in all sediment samples. The mean detection of these 42 PAHs across the sampled sites was about 61 percent, with minimum and maximum detection percentages of 29.3 and 85.4 percent, respectively (fig. $9 A$ ). Total non-normalized PAH concentrations ranged from 0.007 to $37.34 \mathrm{mg} / \mathrm{kg}$, with a mean of $1.49 \mathrm{mg} / \mathrm{kg}$ (fig. $9 B$ ). TOC-normalized total PAH concentrations ranged from 7.28 to $989.93 \mathrm{mg} / \mathrm{kg}$, with a mean of $109.25 \mathrm{mg} / \mathrm{kg}$. 

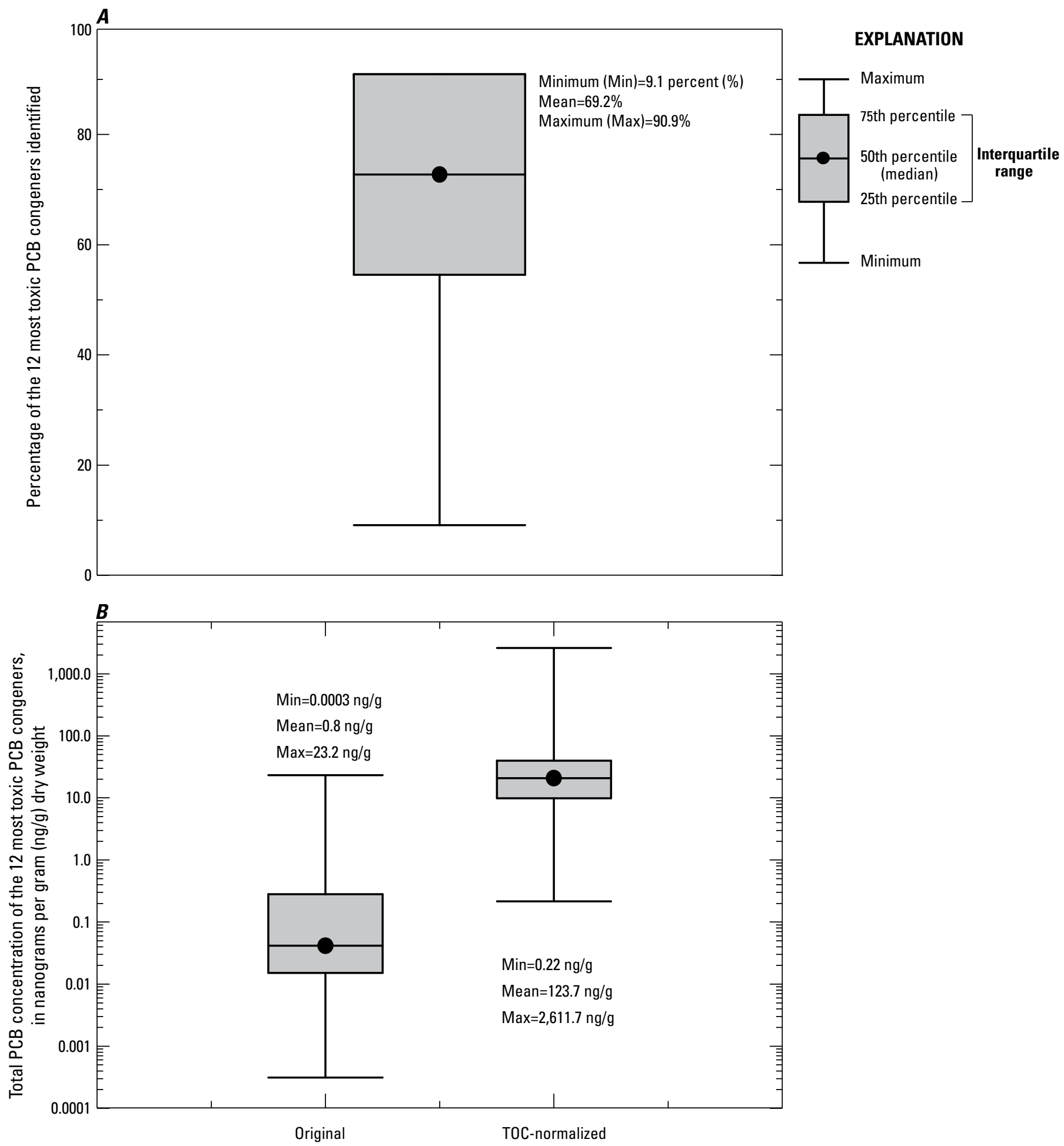

Original concentration or total organic carbon (TOC)-normalized

Figure 4. Percentage of the 12 most toxic polychlorinated biphenyl $(P C B)$ congeners $(A)$, and total and total organic carbon-normalized total of the 12 most toxic PCB congener concentrations $(B)$, detected at the 41 nearshore sediment sites, Puget Sound, western Washington. Only those congeners with concentrations greater than detection limits were included in total concentrations. 


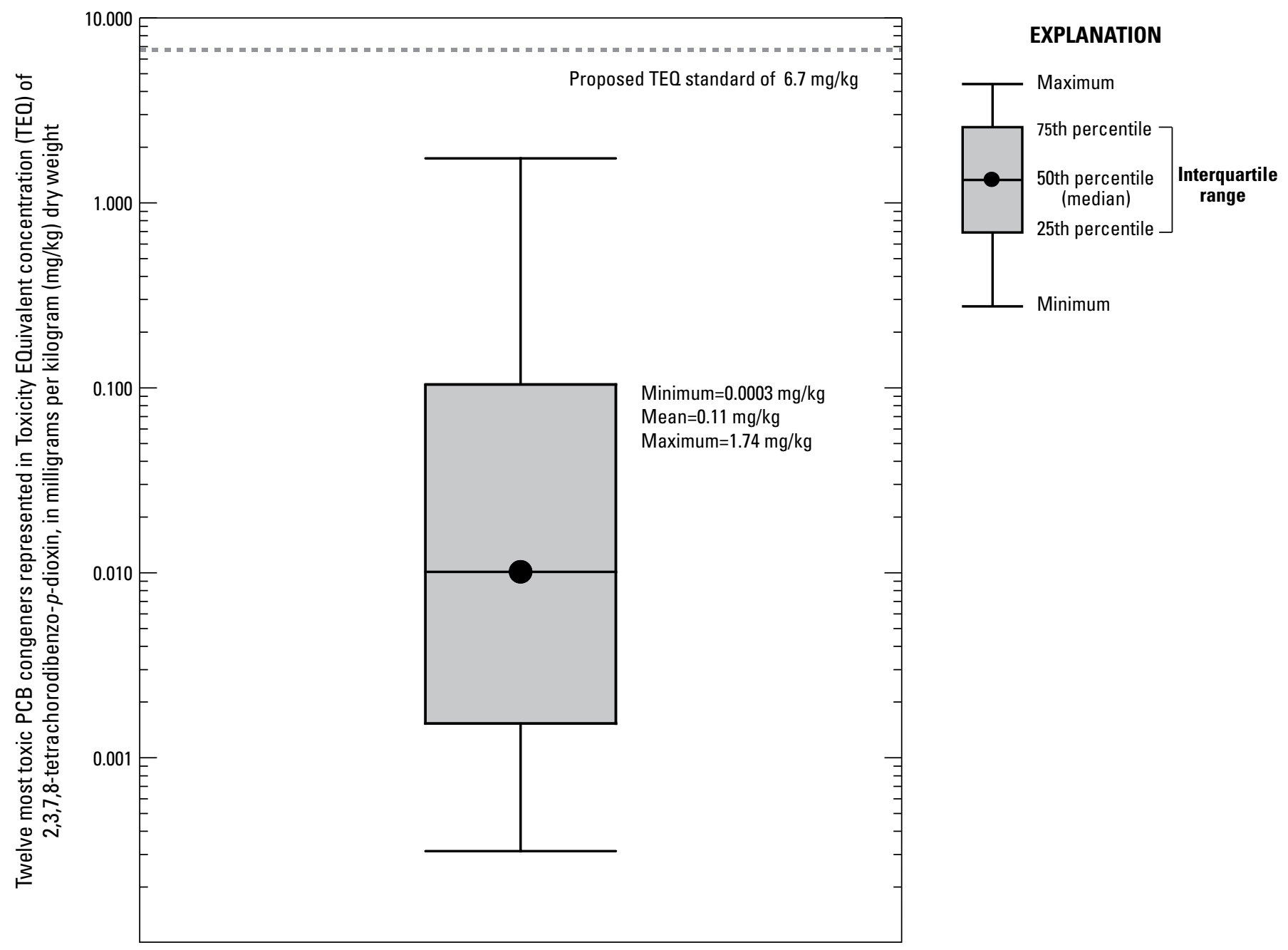

Figure 5. Twelve most toxic polychlorinated biphenyl (PCB) congeners represented as a Toxicity EQuivalent concentration (TEQ) of 2,3,7,8-tetrachorodibenzo- $p$-dioxin at the 41 nearshore sediment sites, Puget Sound, western Washington. Only those congeners with concentrations greater than detection limits were included in total concentrations. 


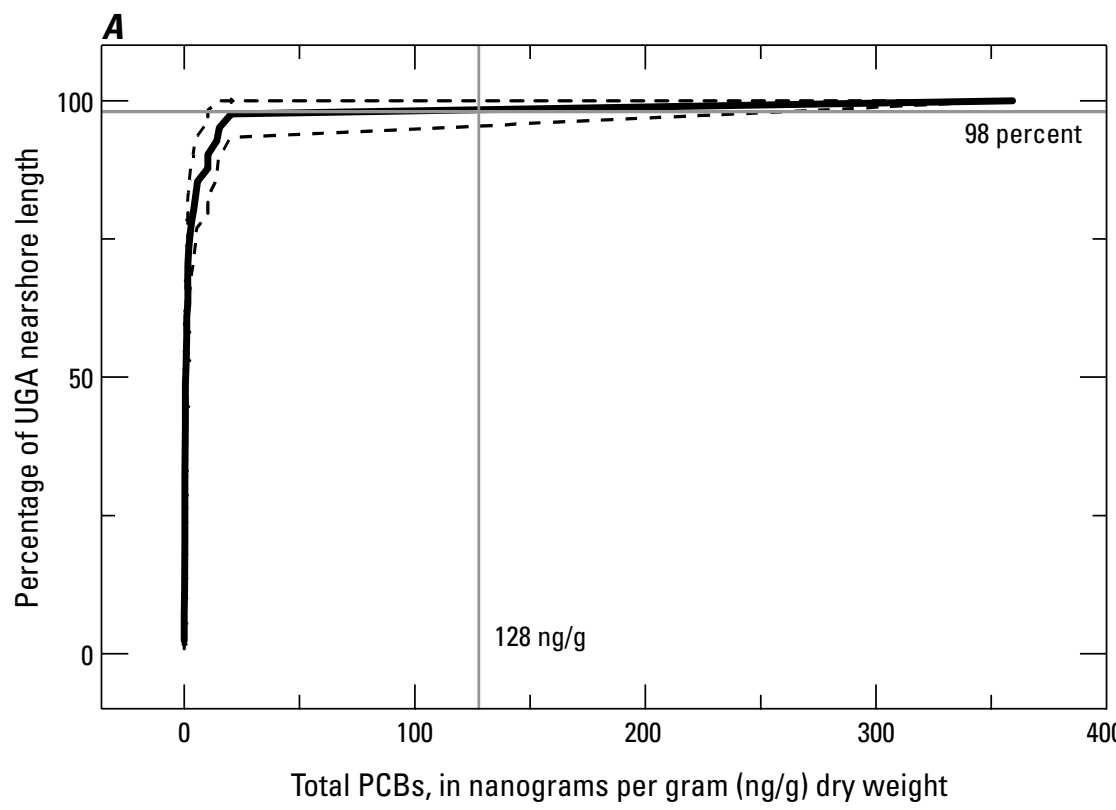

\section{EXPLANATION}

Estimate of the cumulative distribution function for the proportion of Urban Growth Area (UGA) nearshore length associated with the indicated chemical concentrations

Upper and lower 95-percent confidence interval of the estimate

Washington State standard or criterion and the associated percentage of UGA nearshore length less than this value

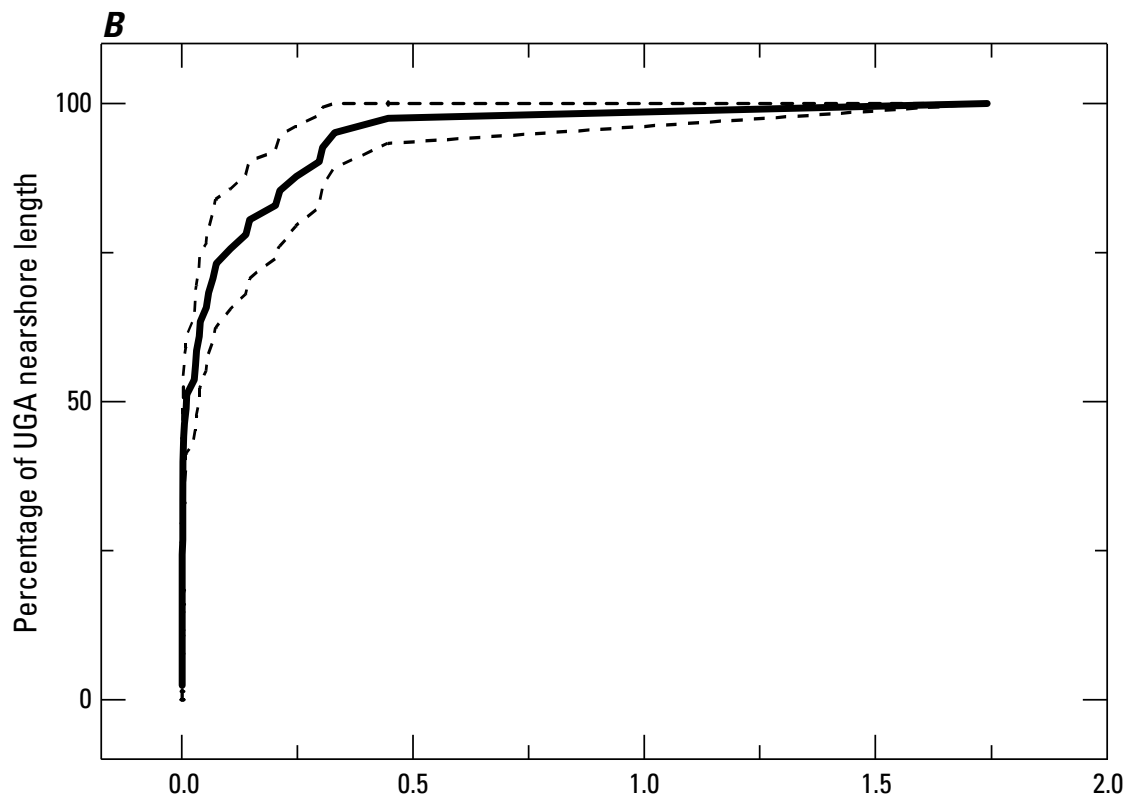

TEO of 12 most toxic PCB congeners, in milligrams per kilogram dry weight

Figure 6. Concentrations of total polychlorinated biphenyls (PCBs) of 209 congeners $(A)$, and Toxicity EQuivalent concentration (TEQ) of the 12 most toxic PCBs in sediment $(B)$, from 41 study sites extrapolated to represent 1,344 kilometers of shoreline of Puget Sound Urban Growth Area, western Washington. 
Table 2. Compound-specific maximum concentrations at various percentages of Urban Growth Area (UGA) nearshore shoreline represented by the Stormwater Action Monitoring sediment study, Puget Sound, western Washington.

[Values in parentheses are 95-percent confidence intervals. All values are based on cumulative distribution function data output from the R statistical package "spsurvey" (Kincaid and Olsen, 2013). Compound: PAH, polycyclic aromatic hydrocarbon; PBDE, polybrominated diphenyl ether; PCB, polychlorinated biphenyl; TEQ, Toxicity EQuivalent concentration; mg/kg, milligram per kilogram; ng/g, nanogram per gram. Abbreviation: km, kilometer]

\begin{tabular}{|c|c|c|c|}
\hline Compound & $\begin{array}{l}\text { Maximum concentration } \\
\text { at } 25 \text { percent }(336 \mathrm{~km}) \text { of } \\
\text { nearshore UGA shoreline }\end{array}$ & $\begin{array}{l}\text { Maximum concentration at } \\
50 \text { percent }(672 \mathrm{~km}) \text { of } \\
\text { nearshore UGA shoreline }\end{array}$ & $\begin{array}{l}\text { Maximum concentration at } \\
75 \text { percent }(1,008 \mathrm{~km}) \text { of } \\
\text { nearshore UGA shoreline }\end{array}$ \\
\hline TEQ-PCB (mg/kg) & $0.0013(0.0009-0.0021)$ & $0.01(0.003-0.03)$ & $0.1(0.04-0.203)$ \\
\hline Total PBDEs (ng/g) & $0.03(0.016-0.04)$ & $0.09(0.05-0.17)$ & $0.42(0.2-2.1)$ \\
\hline Total PAHs (mg/g) & $0.038(0.024-0.051)$ & $0.1(0.06-0.24)$ & $0.5(0.22-1.1)$ \\
\hline Acenaphthylene (mg/kg) & $0.0005(0.00049-0.00051)$ & $0.0006(0.0005-0.0021)$ & $0.0047(0.002-0.0078)$ \\
\hline Anthracene (mg/kg) & $0.0004(0.0003-0.0008)$ & $0.0014(0.0008-0.006)$ & $0.01(0.0062-0.02577)$ \\
\hline Benz $[a]$ anthracene $(\mathrm{mg} / \mathrm{kg})$ & $0.0006(0.0004-0.0015)$ & $0.003(0.002-0.011)$ & $0.021(0.012-0.04)$ \\
\hline $\operatorname{Benzo}(a)$ pyrene $(\mathrm{mg} / \mathrm{kg})$ & $0.0013(0.001-0.0029)$ & $0.0048(0.003-0.014)$ & $0.0238(0.0138-0.04068)$ \\
\hline $\operatorname{Benzo}(g, h, i)$ perylene $(\mathrm{mg} / \mathrm{kg})$ & $0.0013(0.0005-0.0017)$ & $0.005(0.002-0.008)$ & $0.018(0.001-0.036)$ \\
\hline Indeno $(1,2,3-c d)$ pyrene $(\mathrm{mg} / \mathrm{kg})$ & $0.0007(0.0004-0.0014)$ & $0.004(0.002-0.006)$ & $0.014(0.0069-0.028)$ \\
\hline Naphthalene $(\mathrm{mg} / \mathrm{kg})$ & $0.001(0.00097-0.0012)$ & $0.0015(0.0012-0.0026)$ & $0.0056(0.0028-0.009)$ \\
\hline Phenanthrene (mg/kg) & $0.002(0.001-0.003)$ & $0.005(0.003-0.012)$ & $0.038(0.012-0.052)$ \\
\hline Pyrene (mg/kg) & $0.002(0.001-0.005)$ & $0.01(0.005-0.03)$ & $0.078(0.036-0.13)$ \\
\hline Arsenic $(\mathrm{mg} / \mathrm{kg})$ & $1.9(1.7-2.1)$ & $2.5(2.2-3.5)$ & $4.4(3.8-5.7)$ \\
\hline Cadmium (mg/kg) & $0.079(0.073-0.089)$ & $0.116(0.09-0.12)$ & $0.58(0.22-0.83)$ \\
\hline Chromium (mg/kg) & $14.2(13-15)$ & $16.7(15-20.7)$ & $24(19-28.3)$ \\
\hline Copper (mg/kg) & $5(4.5-5.6)$ & $7(5.8-9)$ & $18.1(10-29)$ \\
\hline Lead $(\mathrm{mg} / \mathrm{kg})$ & $1.99(1.66-2.55)$ & $4.25(2.8-5.78)$ & $7.9(5.9-13.5)$ \\
\hline Mercury (mg/kg) & $0.014(0.011-0.017)$ & $0.026(0.018-0.037)$ & $0.059(0.046-0.074)$ \\
\hline Zinc $(\mathrm{mg} / \mathrm{kg})$ & $19.9(19.5-22)$ & $24.1(22-27.9)$ & $46.5(30.1-67.2)$ \\
\hline
\end{tabular}

A CDF plot of total PAHs indicating the percentage of the 1,344-km UGA nearshore less than or equal to specific concentrations is presented in figure 10. Like the PCB curves, the total PAH plot indicates that concentrations are very low for a very high percentage of nearshore UGA sediment. As with total PBDEs, there is no marine sediment criterion for total PAHs. However, the data presented in figure 10 and table 2 also can be used in a similar manner to that of total PBDEs to characterize current conditions as well as to evaluate changes over time.

Although criteria for total PAH concentration in marine sediments do not exist in Washington, criteria for select PAHs do exist. The results for these individual PAH compounds and the Washington State criteria are presented in table 3 for the original and TOC-normalized concentrations. Site-specific values are presented in appendix 4. Criteria for each of these PAHs are for the original concentrations. Of the 15 PAHs analyzed, concentrations of 9 of them were determined to be greater than the criteria at one site, and concentrations of 1 of them were determined to be greater than the criteria at two sites. Of the two sampled sites with concentrations greater than criteria, both were in areas with minimal water movement and were adjacent to areas with light industry and active rail lines. The PAHs with the largest concentration exceedances of criteria were fluoranthene and pyrene (table 3). 


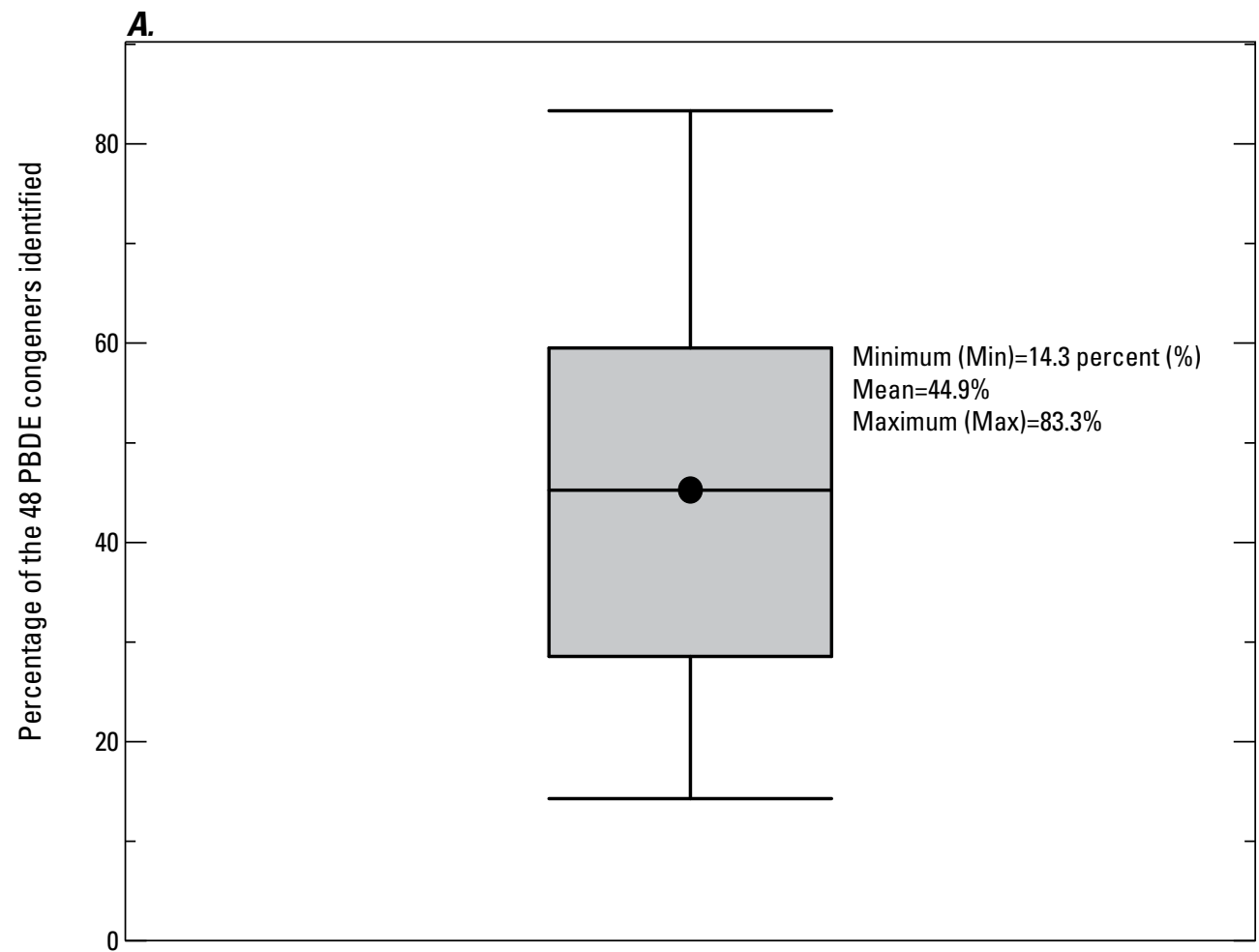

\section{EXPLANATION}
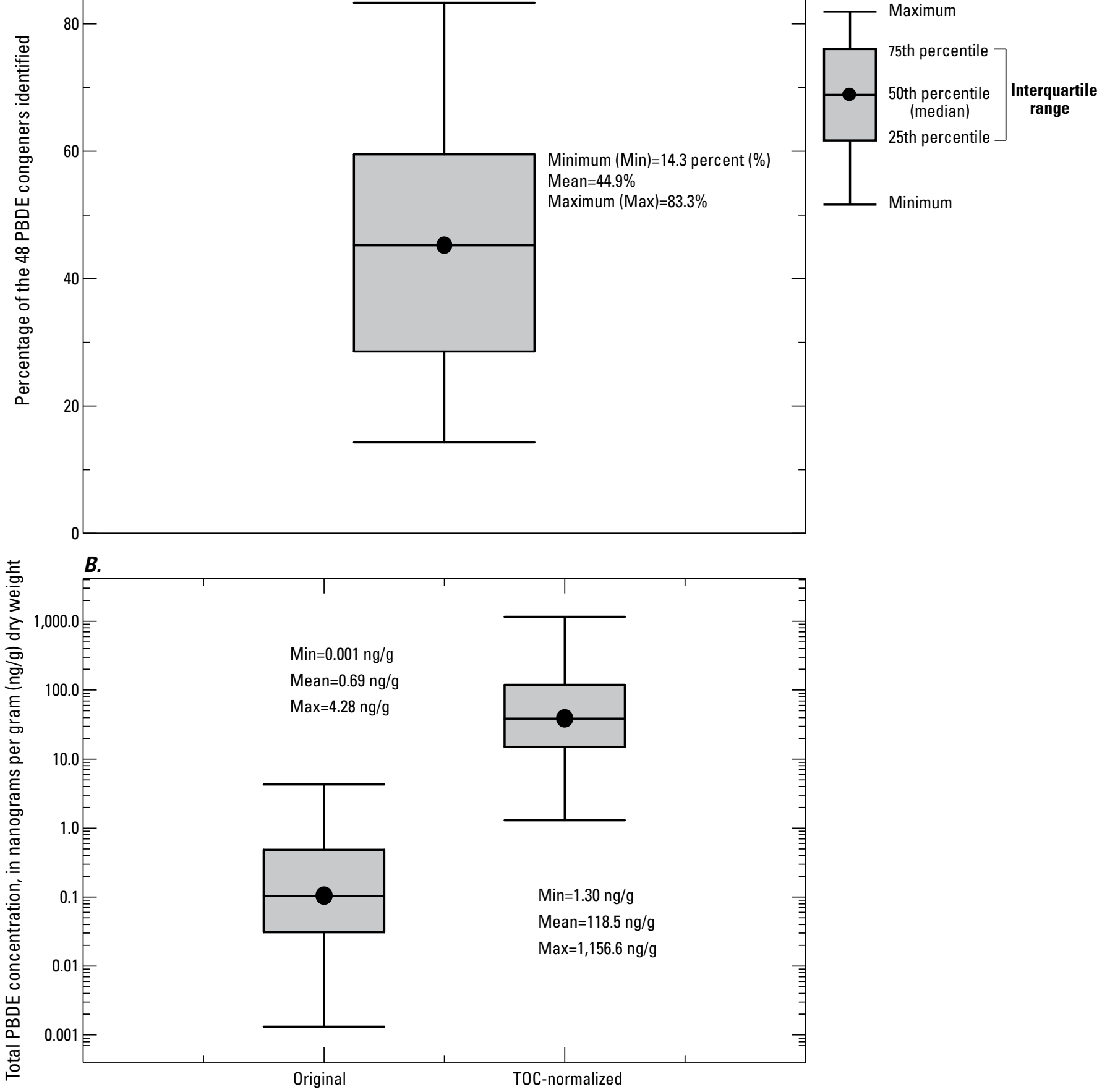

Original concentration or total organic carbon (TOC)-normalized

Figure 7. Percentage of the 48 polybrominated diphenyl ether (PBDE) congeners $(A)$, and total and total organic carbon-normalized total PBDE concentrations $(B)$, detected at the 41 nearshore sediment sites, Puget Sound, western Washington. Only those congeners with concentrations greater than detection limits were included in total concentrations. 


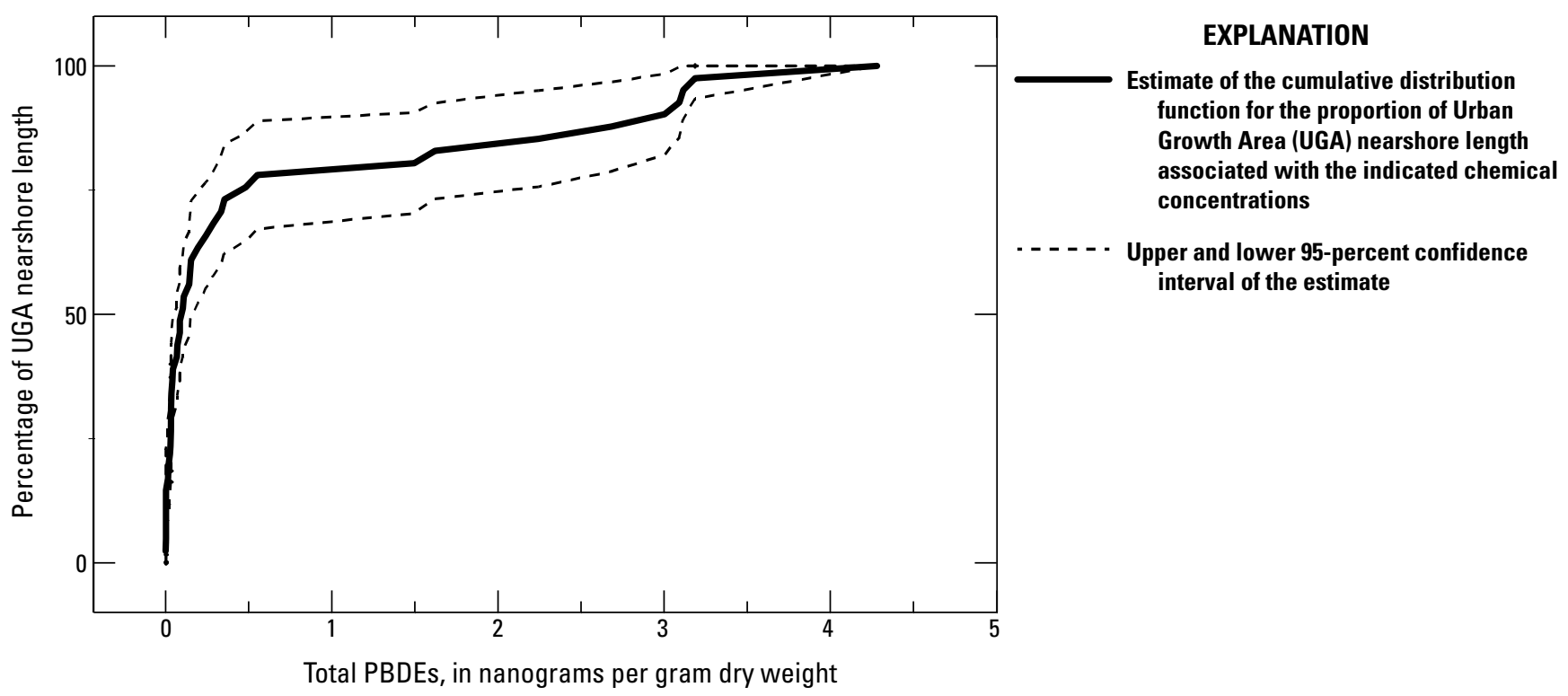

Figure 8. Concentrations of total polybrominated diphenyl ethers (PBDEs) (48 congeners) in sediment from 41 study sites, representing 1,344 kilometers of shoreline of the Puget Sound Urban Growth Area, western Washington.

CDF plots for each of each of the individual PAHs with criteria were generated to determine what percentage of the SAM UGA nearshore environment exceeded specific criteria. These plots are shown in figure 11. For many of the PAHs with criteria (2-methylnaphthalene, acenaphthene, acenaphthylene, fluorene, naphthalene), field sample concentrations were all less than the criteria. This resulted in CDF plots for these compounds that indicate 100 percent of the UGA nearshore shoreline sediment has concentrations less than the Washington State criteria. The remaining PAHs had one or two samples with concentrations greater than the State criteria. Based on these plots, more than 96 percent of the UGA nearshore sediment has concentrations less than State marine criteria. Like the PCB plots, the individual PAH plots show a very rapid rise to 100 percent, suggesting a narrow range in individual PAH concentrations across the nearshore
UGA sediment shoreline. As with total PCBs, PBDEs and PAHs, the maximum concentrations at 25,50 , and 75 percent of the 1,344-km nearshore UGA shoreline examined in this study are presented in table 2 .

\section{Phthalate Concentrations}

For the nearshore sediment study, samples were analyzed for six phthalates. Of these 6 compounds, diethyl phthalate was the only compound detected in more than 5 percent of the sites (table 4). Site-specific phthalate concentrations are shown in appendix 5. CDF plots for the phthalates with Washington State criteria were not produced, given that only one or two sites had samples with concentrations greater than the detection limits (making such plots of no practical value to this study). 


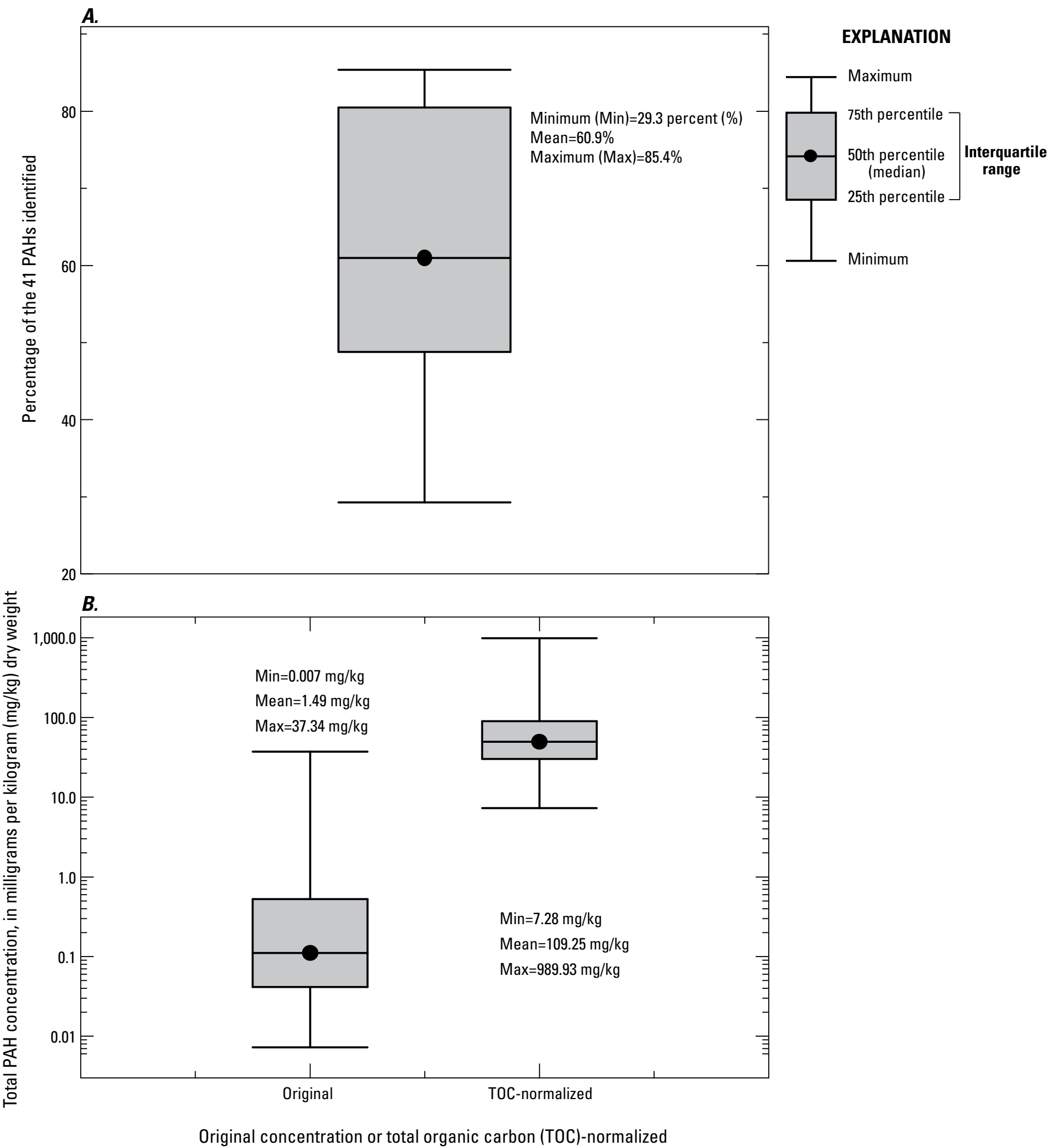

Figure 9. Percentage of the 42 polycyclic aromatic hydrocarbon (PAH) compounds $(A)$, and total and total organic carbon-normalized total PAH concentrations $(B)$, detected at the 41 nearshore sediment sites, Puget Sound, western Washington. Only those PAH compounds with concentrations greater than detection limits were included in total concentrations. 


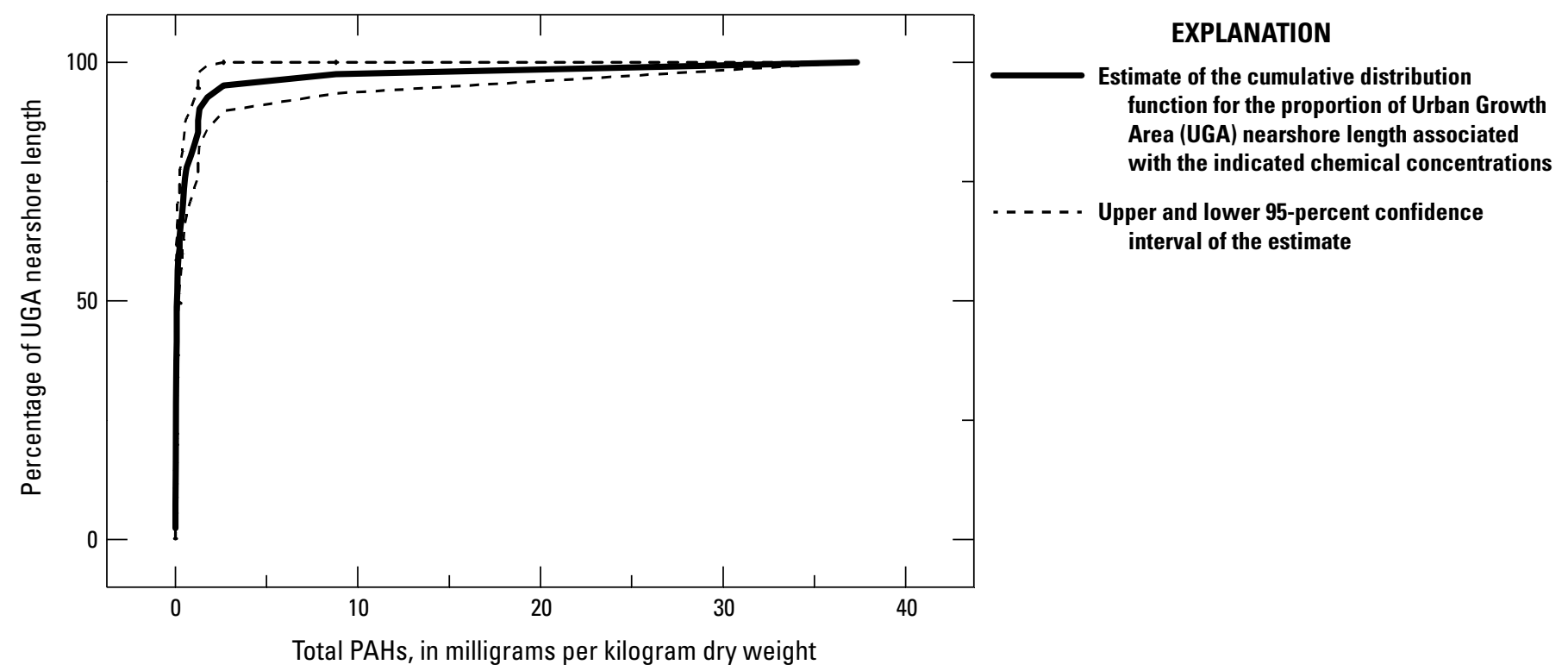

Figure 10. Concentrations of total polycyclic aromatic hydrocarbons (PAHs; 42 compounds) in sediment from 41 study sites, representing 1,344 kilometers of shoreline of the Puget Sound Urban Growth Area, western Washington.

Table 3. Summary statistics for concentrations of polycyclic aromatic hydrocarbon compounds, with corresponding Washington State sediment criteria, collected at the 41 Stormwater Action Monitoring sampling sites, and sediment samples collected as part of the Puget Sound Ecosystem and Monitoring Program (Dutch and others, 2009), Puget Sound, western Washington, 2002-14.

[Mean values were calculated using the approach outlined in Helsel (2005). Bold values indicate concentrations greater than the Washington State marine sediment criteria. PAH compound: polycyclic aromatic hydrocarbon compound. Criteria: Washington State sediment concentration criteria for PAH compounds. Sites > criteria: Sites with PAH concentrations greater than criteria; -, no sites for this PAH compound had concentrations greater than this criteria. Min.: Minimum. Max.: Maximum. Abbreviations: mg/kg, milligram per kilogram; nd, less than detection limit]

\begin{tabular}{|c|c|c|c|c|c|c|c|c|c|c|c|c|}
\hline \multirow[t]{2}{*}{ PAH compound } & \multirow[t]{2}{*}{$\begin{array}{l}\text { Percent } \\
\text { detection }\end{array}$} & \multicolumn{3}{|c|}{$\begin{array}{c}\text { Original value } \\
\text { (mg/kg, dry weight) }\end{array}$} & \multirow[t]{2}{*}{$\begin{array}{c}\text { Criteria } \\
\text { (mg/kg, } \\
\text { dry weight) }\end{array}$} & \multirow[t]{2}{*}{$\begin{array}{c}\text { Sites } \\
>\text { criteria }\end{array}$} & \multicolumn{3}{|c|}{$\begin{array}{l}\text { Total organic carbon- } \\
\text { normalized concentration } \\
\text { (mg/kg, dry weight) }\end{array}$} & \multicolumn{3}{|c|}{$\begin{array}{l}\text { Puget Sound Ecosystem } \\
\text { Monitoring Program } \\
\text { results, 2002-14 } \\
\text { (mg/kg, dry weight) }\end{array}$} \\
\hline & & Min. & Mean & Max. & & & Min. & Mean & Max. & Min. & Mean & Max. \\
\hline 2-Methylnaphthalene & 68 & nd & 0.01 & 0.26 & 0.67 & - & nd & 0.65 & 3.40 & nd & 0.03 & 0.26 \\
\hline Anthracene & 85 & nd & 0.04 & 1.03 & 0.96 & 11 & nd & 2.33 & 16.85 & nd & 0.03 & 0.89 \\
\hline Benz $[a]$ anthracene & 98 & nd & 0.06 & 1.63 & 1.30 & 11 & nd & 4.23 & 39.44 & nd & 0.03 & 1.22 \\
\hline $\operatorname{Benzo}(a)$ pyrene & 90 & nd & 0.06 & 1.70 & 1.60 & 11 & nd & 4.88 & 31.35 & nd & 0.04 & 1.02 \\
\hline $\operatorname{Benzo}(g, h, i)$ perylene & 100 & 0.000 & 0.05 & 1.38 & 0.67 & 11 & 0.17 & 3.70 & 25.69 & nd & 0.03 & 0.51 \\
\hline Chrysene & 100 & 0.000 & 0.10 & 2.42 & 1.40 & 11 & 0.25 & 7.96 & 68.20 & nd & 0.06 & 1.91 \\
\hline $\operatorname{Dibenzo}(a, h)$ anthracene & 78 & nd & 0.01 & 0.32 & 0.23 & 11 & nd & 1.07 & 7.12 & nd & 0.01 & 0.18 \\
\hline Naphthalene & 73 & nd & 0.03 & 0.94 & 2.10 & - & nd & 1.83 & 14.28 & nd & 0.07 & 1.48 \\
\hline Phenanthrene & 95 & nd & 0.12 & 3.71 & 1.50 & 11 & nd & 6.12 & 47.87 & nd & 0.09 & 1.46 \\
\hline Pyrene & 100 & 0.000 & 0.30 & 6.47 & 2.60 & 11,43 & 0.31 & 21.27 & 441.57 & nd & 0.08 & 2.15 \\
\hline
\end{tabular}



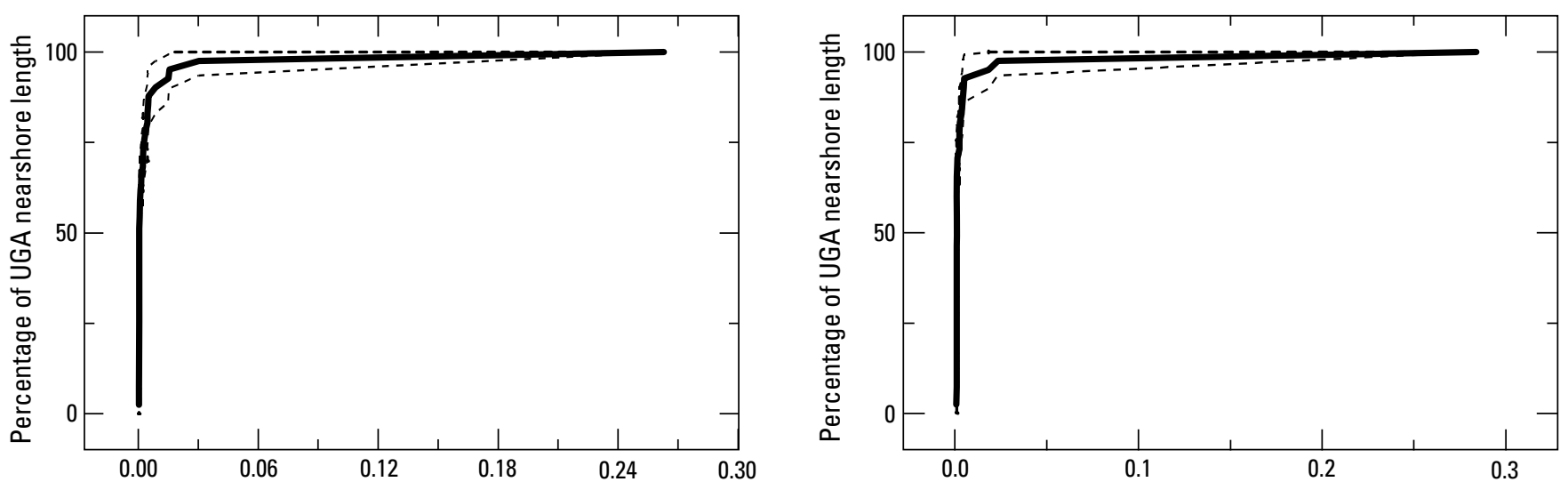

2-methylnaphthalene, in milligrams per kilogram dry weight

Acenaphthene, in milligrams per kilogram dry weight
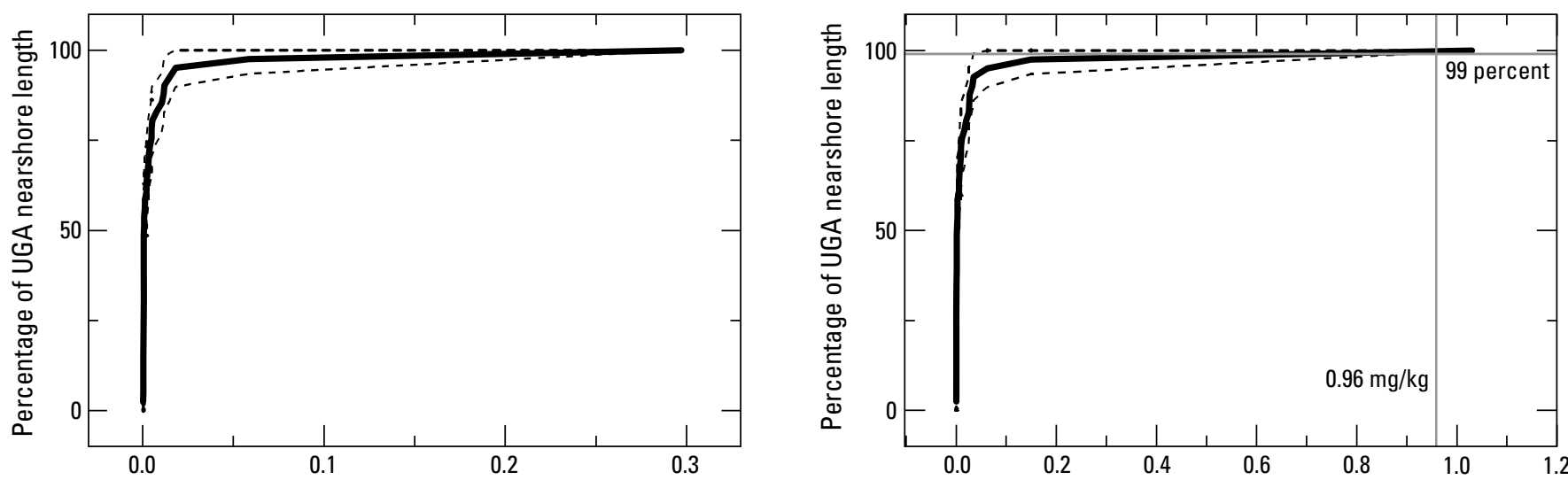

Acenaphthylene, in milligrams per kilogram dry weight

Anthracene, in milligrams per kilogram $(\mathrm{mg} / \mathrm{kg})$ dry weight

\section{EXPLANATION}

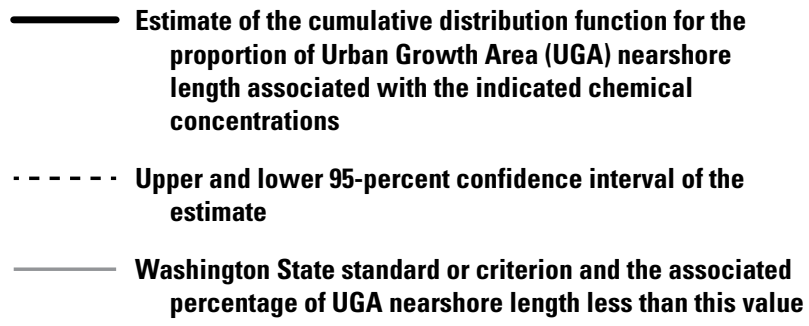

Figure 11. Concentrations of 15 polycyclic aromatic hydrocarbons with Washington State marine sediment criteria in sediment from 41 study sites representing 1,344 kilometers $(\mathrm{km})$ of shoreline of the Puget Sound Urban Growth Area (UGA), western Washington. Phthalate sediment concentrations in 100 percent of the 1,344 km of Puget Sound UGA shoreline were less than the Washington State criteria, unless noted otherwise. To effectively generate the cumulative distribution functions, one-half of the detection limit was used for all non-detects. 


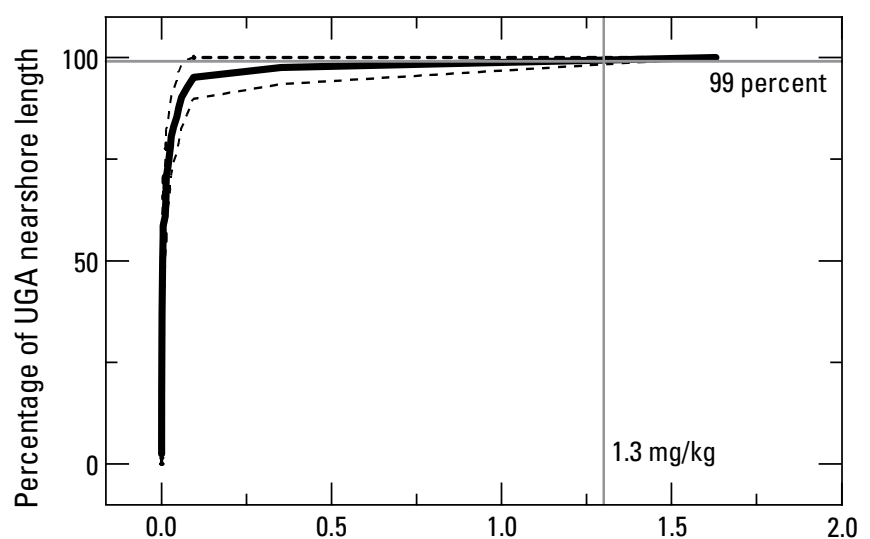

Benz[a]anthracene, in milligrams per kilogram $(\mathrm{mg} / \mathrm{kg})$ dry weight

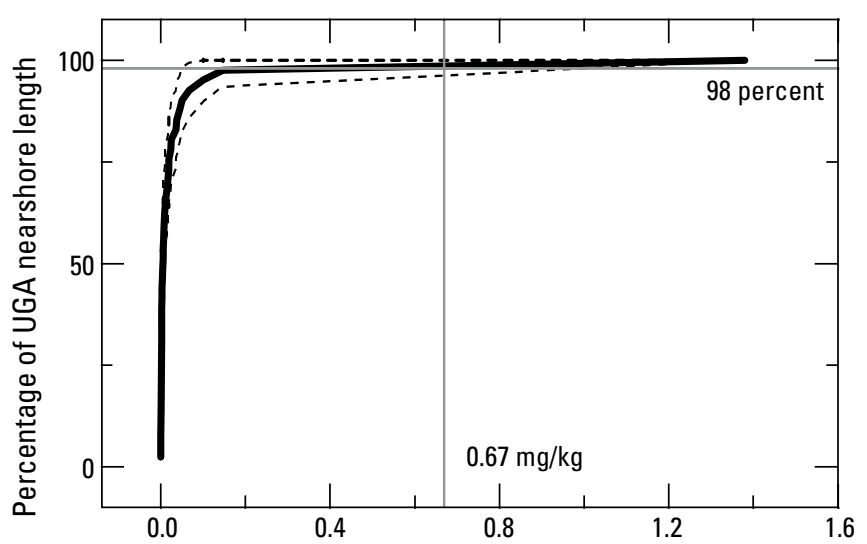

Benzo( $g, h, i)$ perylene, in milligrams per kilogram $(\mathrm{mg} / \mathrm{kg})$ dry weight

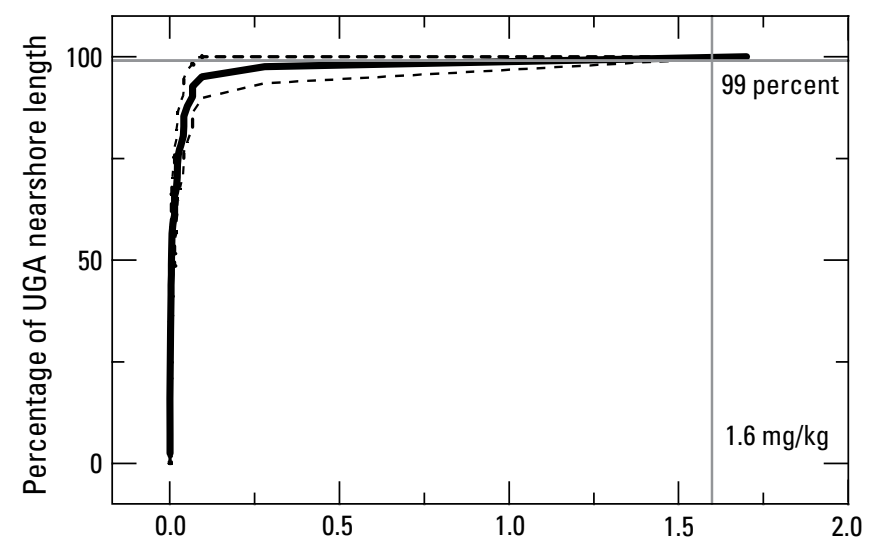

Benzo(a)pyrene, in milligrams per kilogram $(\mathrm{mg} / \mathrm{kg})$ dry weight

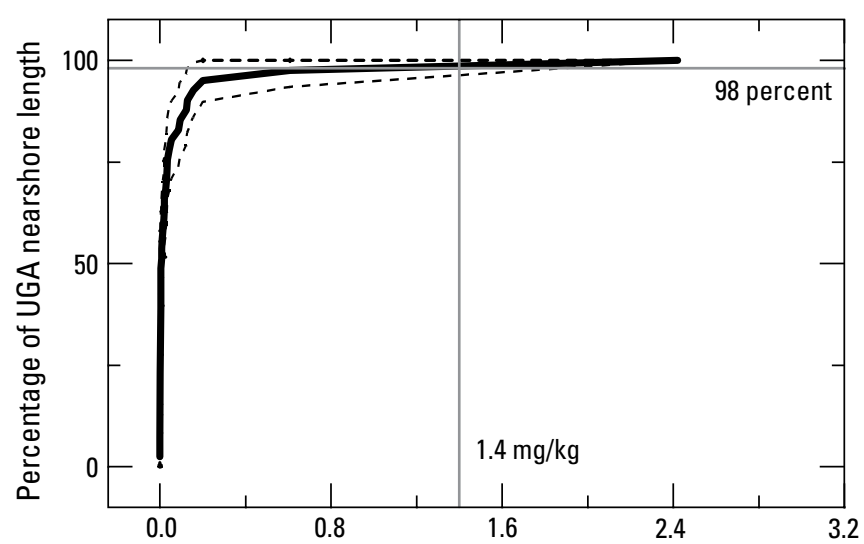

Chrysene, in milligrams per kilogram (mg/kg) dry weight

Figure 11. Continued. 


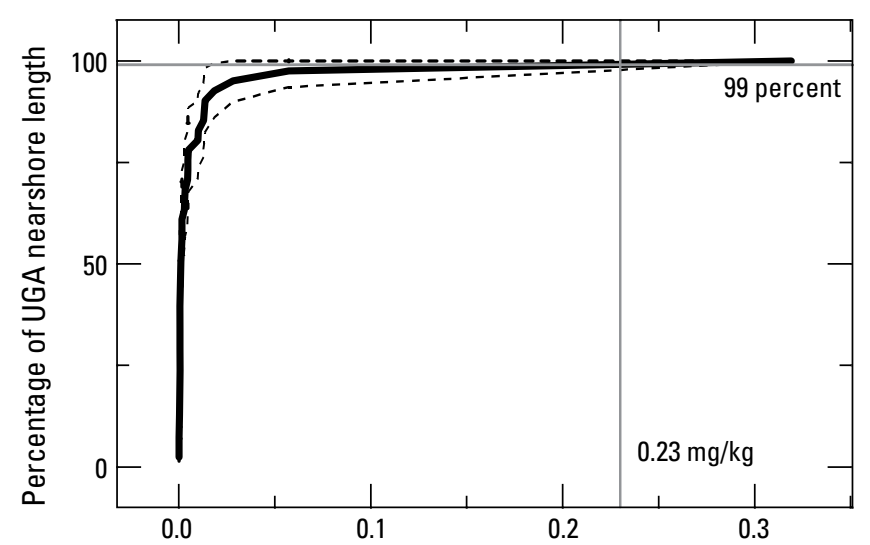

Dibenzo( $a, h)$ anthracene, in milligrams per kilogram $(\mathrm{mg} / \mathrm{kg})$ dry weight

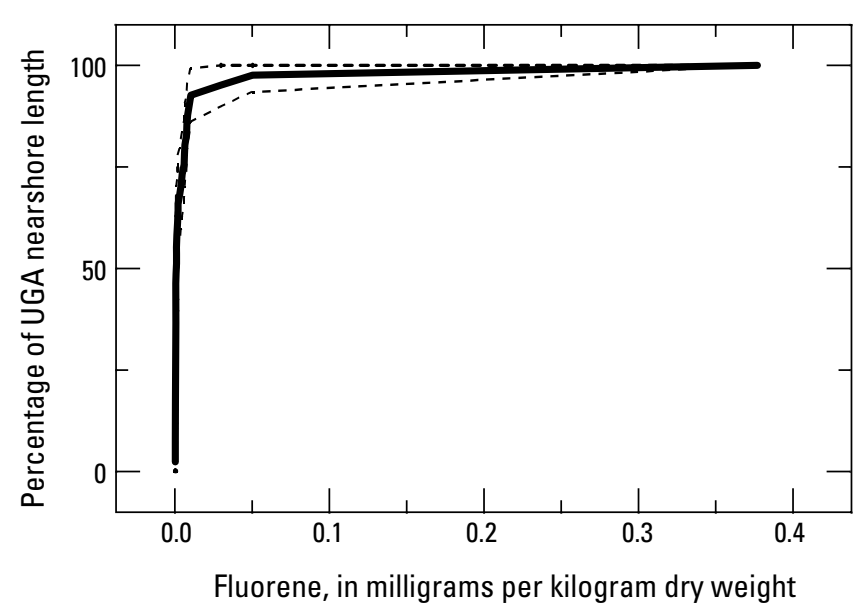

Figure 11. Continued.

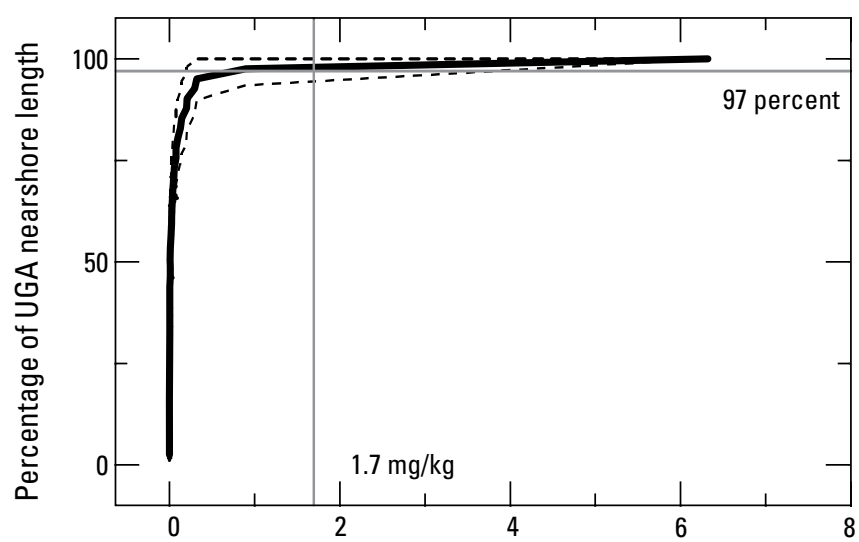

Fluoranthene, in milligrams per kilogram $(\mathrm{mg} / \mathrm{kg})$ dry weight

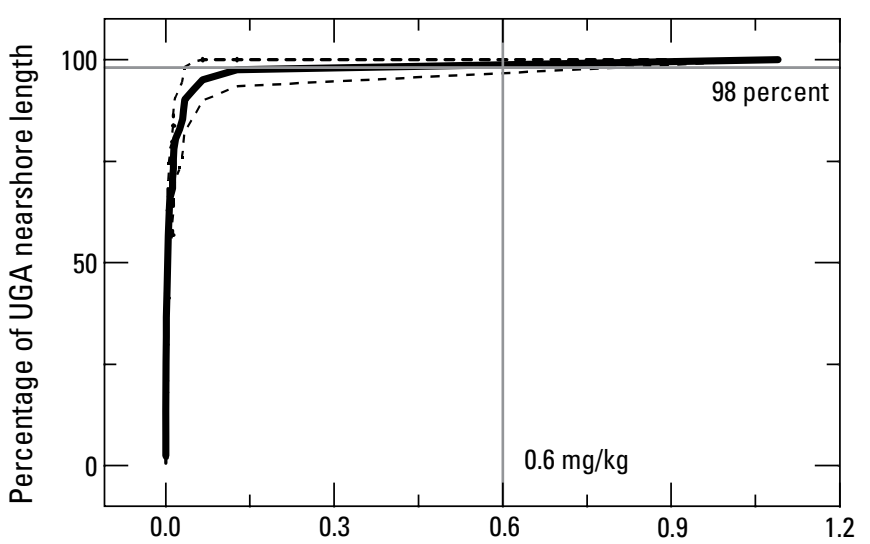

Indeno $(1,2,3-c d)$ pyrene, in milligrams per kilogram $(\mathrm{mg} / \mathrm{kg})$ dry weight 

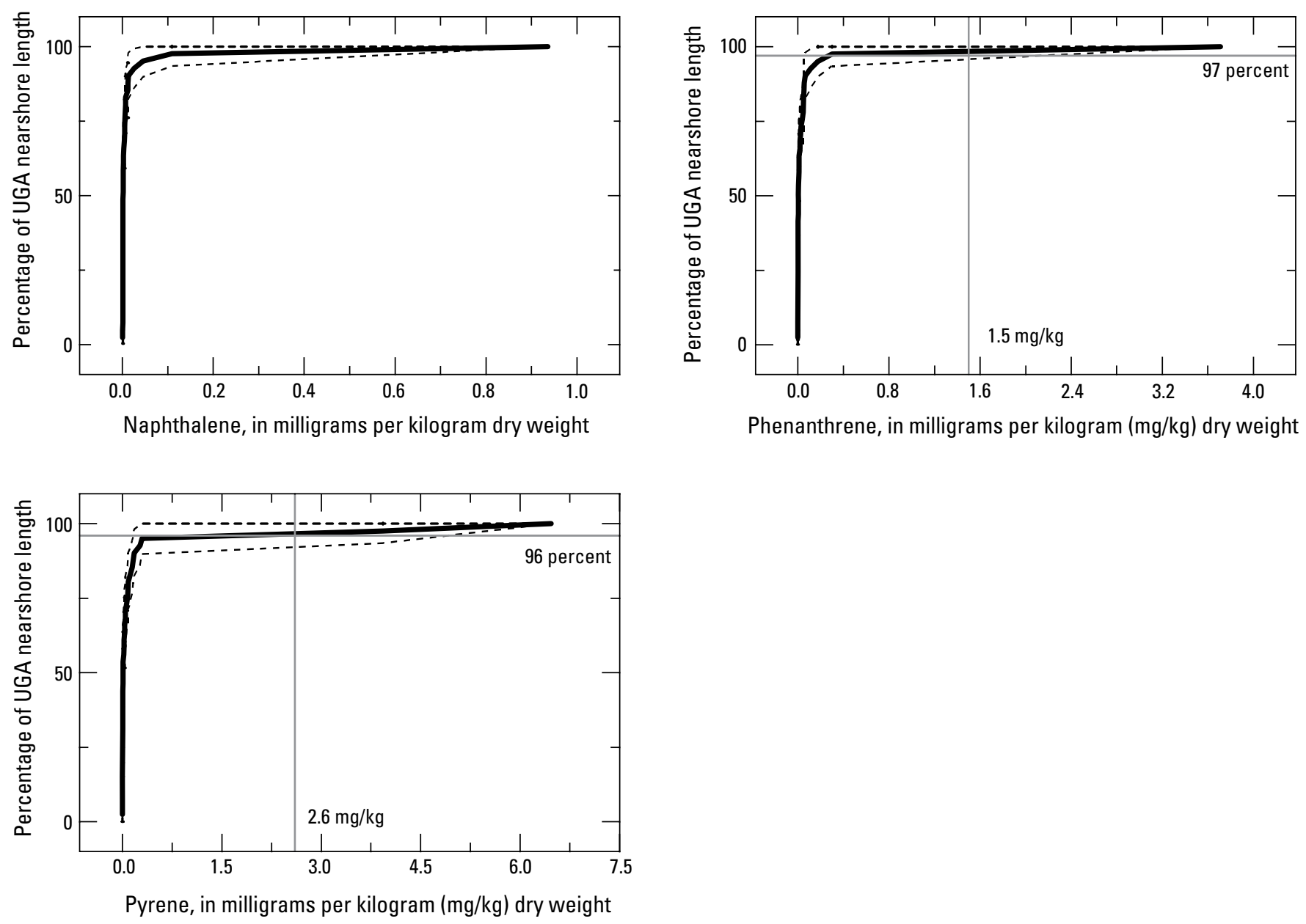

Phenanthrene, in milligrams per kilogram $(\mathrm{mg} / \mathrm{kg})$ dry weight

Figure 11. Continued.

Table 4. Summary statistics for phthalate concentrations with Washington State sediment criteria from 41 Stormwater Action Monitoring sampling sites, Puget Sound, western Washington.

[Mean values were calculated using the approach outlined in Helsel (2005) to account for those concentrations less than detection limits. Min.: Minimum; nd, less than detection limit. Max.: Maximum. Criteria: Washington State sediment concentration criteria for phthalates. Abbreviation: $\mathrm{mg} / \mathrm{kg}$, milligram per kilogram]

\begin{tabular}{|c|c|c|c|c|c|c|c|c|}
\hline \multirow{2}{*}{ Phthalates } & \multirow{2}{*}{$\begin{array}{l}\text { Percent } \\
\text { detection }\end{array}$} & \multicolumn{3}{|c|}{$\begin{array}{c}\text { Original value } \\
\text { (mg/kg, dry weight) }\end{array}$} & \multirow{2}{*}{$\begin{array}{c}\text { Criteria } \\
\text { (mg/kg, dry weight) }\end{array}$} & \multicolumn{3}{|c|}{$\begin{array}{l}\text { Total organic carbon-normalized } \\
\text { concentration (mg/kg, dry weight) }\end{array}$} \\
\hline & & Min. & Mean & Max. & & Min. & Mean & Max. \\
\hline Butyl benzyl phthalate & 3 & nd & 0.03 & 0.03 & 0.063 & nd & 26.80 & 26.80 \\
\hline Diethyl phthalate & 49 & nd & 0.02 & 0.14 & 0.200 & nd & 6.40 & 61.10 \\
\hline Dimethyl phthalate & 3 & nd & 0.06 & 0.06 & 0.071 & nd & 0.81 & 0.80 \\
\hline Di- $n$-octyl phthalate & 3 & nd & 0.03 & 0.03 & 6.200 & nd & 30.36 & 30.40 \\
\hline
\end{tabular}




\section{Metal Concentrations and Extrapolation to the Stormwater Action Monitoring Nearshore}

For the 11 metals analyzed during this study, 8 metals have marine sediment criteria (table 5). All the metals except silver were present in greater than 90 percent of the sites. However, concentrations of the eight metals were less than the Washington State criteria. Site-specific metal concentrations are shown in appendix 6 .

Unlike the organic compounds, the metals had a much greater diversity of concentrations across the population of sampling sites (fig. 12). This increased diversity is represented by CDF plots that do not rise as rapidly as those for the organics and have much broader confidence intervals. None of the metal samples collected as part of the 41 site sampling activities had metal concentrations exceeding Washington State criteria (table 5). The CDF plots for each of the metals with criteria indicate that 100 percent of the UGA nearshore shoreline have metal concentrations less than State marine sediment criteria. As with the organics, the maximum concentrations at 25,50 , and 75 percent of the $1,344-\mathrm{km}$ nearshore UGA shoreline examined in this study are presented in table 2.

\section{Sediment Chemistry Concentrations in Relation to Land-Use and Geologic Features}

A stepwise linear regression analysis was done on numerous chemical constituents with no censored values. The results of these analyses are shown in table 6. Although all the regression models and predictor variables were significant at the $p=0.05$ level, the amount of the variation $\left(r^{2}\right)$ in each of the chemical concentrations explained by the predictor variables was very low, and ranging from a low of 13 percent for total PCBs to a high of 58 percent for copper. In most cases, the stepwise procedure identified only one significant predictor variable, which often was the percentage of clay in each of the samples. For total PCBs, a total of the 12 most toxic PCBs and lead, the abundance of urban land cover in the adjacent watershed was determined to be the most significant predictor variable. However, these models explained only 13-14 percent of the variation in PCB concentrations and 26 percent of the variation in lead concentrations. In some cases, the stepwise regression procedure identified significant two-predictor variable models (table 6). For three of these chemicals, the percentage of clay in the sample and the percentage of shoreline urban land cover were the most significant predictor variable. These models were for chromium, copper, and zinc.

Table 5. Summary statistics for metal concentrations for 41 Stormwater Action Monitoring sampling sites and sediment samples collected as part of the Puget Sound Ecosystem and Monitoring Program (Dutch and others, 2009), Puget Sound, western Washington, 2002-14.

[Mean values were calculated using the approach outlined in Helsel (2005) to account for those concentrations less than detection limits. Min.: Minimum; nd, less than detection limit. Max.: Maximum. Criteria: Washington State sediment concentration criteria for metals; -, No Washington State criteria exist for this metal. Abbreviation: $\mathrm{mg} / \mathrm{kg}$, milligram per kilogram]

\begin{tabular}{|c|c|c|c|c|c|c|c|c|}
\hline \multirow[t]{2}{*}{ Metals } & \multirow{2}{*}{$\begin{array}{l}\text { Percent } \\
\text { detection }\end{array}$} & \multicolumn{3}{|c|}{$\begin{array}{l}\text { Nearshore sediment } \\
\text { (mg/kg, dry weight) }\end{array}$} & \multirow{2}{*}{$\begin{array}{c}\text { Criteria } \\
\text { (mg/kg, dry } \\
\text { weight) }\end{array}$} & \multicolumn{3}{|c|}{$\begin{array}{l}\text { Puget Sound Ecosystem Monitoring Program } \\
\text { results, 2002-14 (mg/kg, dry weight) }\end{array}$} \\
\hline & & Min. & Mean & Max. & & Min. & Mean & Max. \\
\hline Cadmium & 98 & nd & 0.40 & 2.23 & 5.1 & nd & 0.48 & 3.78 \\
\hline Chromium & 100 & 6.79 & 21.49 & 90.60 & 260 & 8.86 & 36.34 & 127.00 \\
\hline Copper & 100 & 3.00 & 15.37 & 82.20 & 390 & 3.09 & 24.36 & 195.00 \\
\hline Mercury & 98 & nd & 0.04 & 0.22 & 0.41 & nd & 0.08 & 0.80 \\
\hline Nickel & 100 & 4.39 & 19.74 & 76.70 & - & 5.69 & 31.70 & 142.00 \\
\hline Selenium & 90 & nd & 0.51 & 2.25 & - & nd & 0.72 & 11.20 \\
\hline Silver & 34 & nd & 0.08 & 0.32 & 6.1 & nd & 0.14 & 1.15 \\
\hline Tin & 100 & 0.16 & 1.72 & 34.10 & - & nd & 0.92 & 5.66 \\
\hline Zinc & 100 & 13.50 & 38.68 & 208.00 & 410 & 16.10 & 63.03 & 492.00 \\
\hline
\end{tabular}



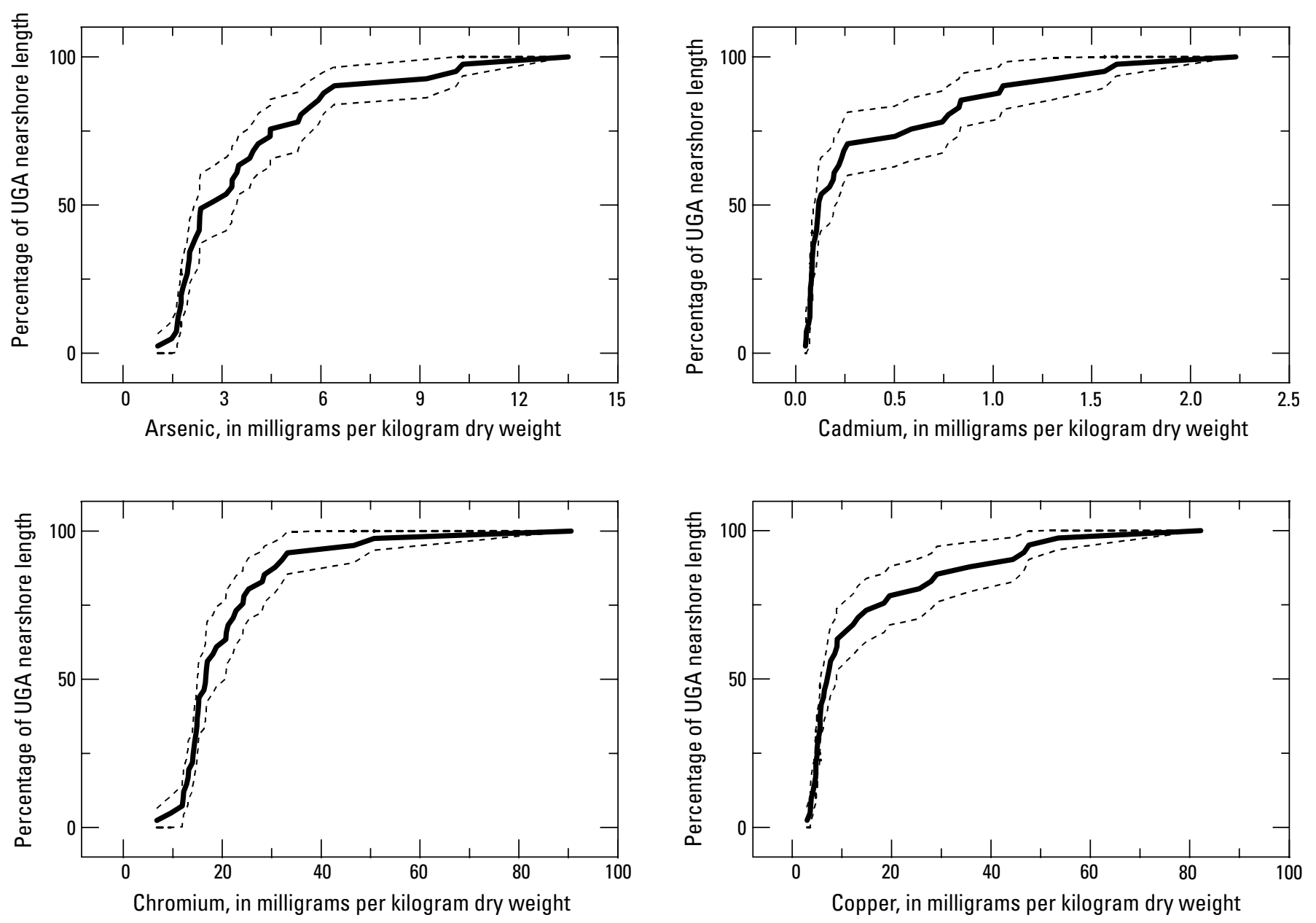

\section{EXPLANATION}

Estimate of the cumulative distribution function for the proportion of Urban Growth Area (UGA) nearshore length associated with the indicated chemical concentrations

- - - - - Upper and lower 95-percent confidence interval of the estimate

Figure 12. Concentrations of seven select metals in sediment from 41 study sites representing 1,344 kilometers (km) of shoreline of the Puget Sound Urban Growth Area (UGA), western Washington. Metal concentrations in 100 percent of the $1,344 \mathrm{~km}$ of Puget Sound UGA shoreline were less than the Washington State criteria. To effectively generate the cumulative distribution functions, one-half of the detection limit was used for all non-detects. 

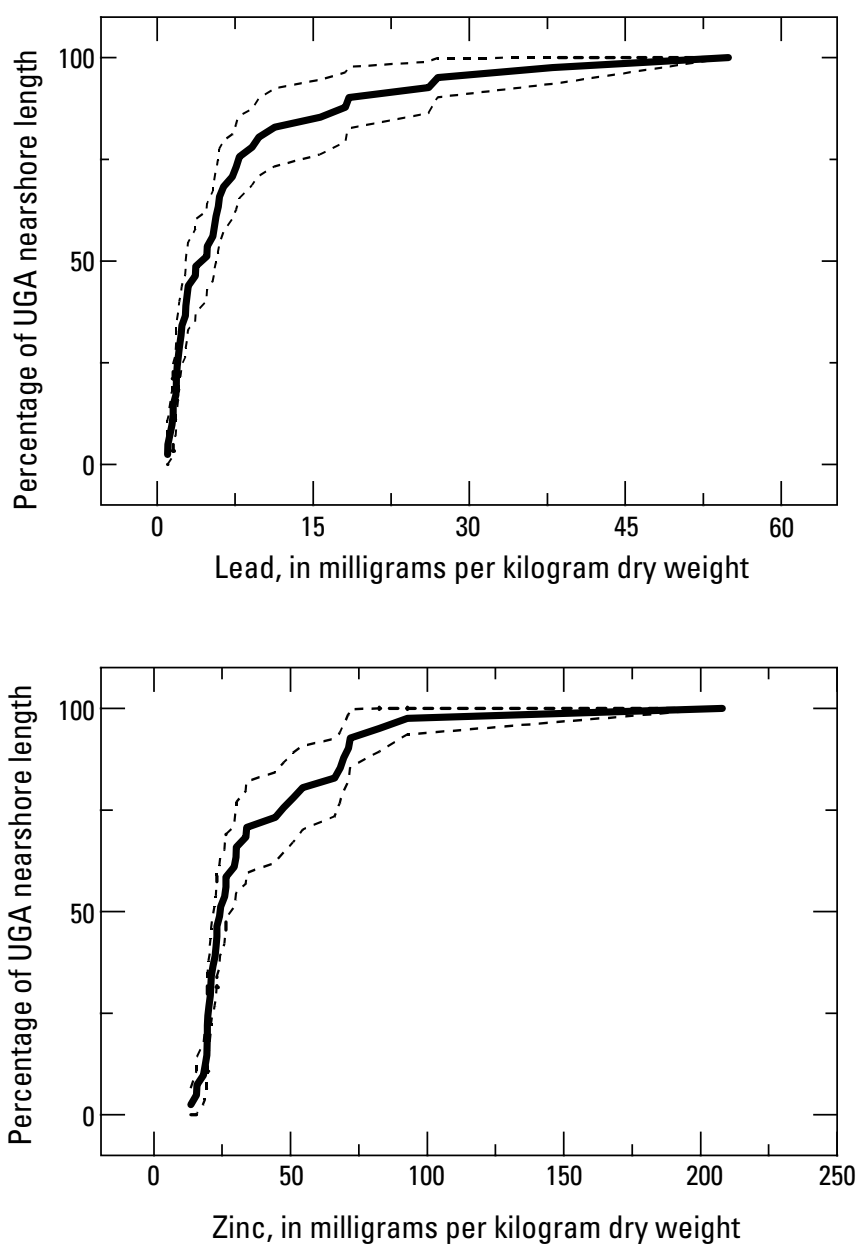

Figure 12. Continued.

The copper and zinc models had $\mathrm{r}^{2}$ values of 0.58 and 0.52 , respectively. The most significant model for mercury included the percentage of agricultural land cover in the watershed and the percentage of clay in the sample, with an $\mathrm{r}^{2}$ value of 0.33 .

A second statistical approach also was used to determine if various land-use, geologic, and (or) physical characteristic of the sediment present at each site were empirically related to the concentrations of the chemicals at each site. The results of the Random Forest analyses are shown in table 7, which indicates the percentage of variation in chemical concentration explained by the explanatory variables and the individual

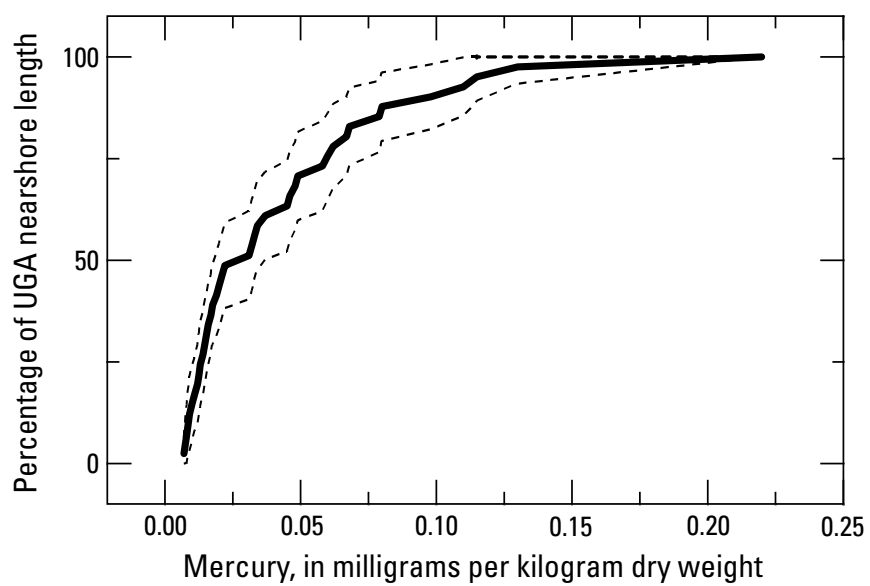

importance of each explanatory variable. The importance values indicate the degree to which the percentage of variance explained is reduced if a particular explanatory variable is removed from the statistical model. For example, the percentage of clay in a sample was the most important ("Clay $\%$ in the sample" in table 7; importance value of 31) variable in explaining the concentration of zinc in the nearshore sediment samples, but the percentage of shoreline urban land use ("NOAA shoreline \% urban" in table 7; importance value of 28) was a close second. 
For all the organics, none of the explanatory variables evaluated explained the variation in the chemical concentrations. However, numerous land-use and physical features of the sediment samples explained the variation in the concentration of many metals (table 7). For example, almost 54 percent of the variation in cadmium concentrations could be explained by the percentages of clay, sand, silt, and agriculture in the watershed (table 7). The lowest percentage of variability explained was for nickel at 8.66 percent. For cadmium, chromium, copper, lead, nickel and zinc, the percentage of shoreline urban or forest land use and the composition of the sediment sample (that is, percentage of clay, sand and silt) generally were important predictors. The stepwise regression (table 6) and Random Forest (table 7) methods produce different results in terms of the percentage of variability in metal concentrations explained by the explanatory variables. These two methods use very different statistical procedures and likely are responding to a relatively small sample size of 41 . Nevertheless, both modeling approaches identified the importance of sediment size in predicting metal concentrations.

Table 6. Stepwise linear regression results for relation between sediment chemical concentrations and land-use and geologic features.

[All models and predictor variables are significant at the $\mathrm{p}=0.05$ level. Chemical: PAHs, polycyclic aromatic hydrocarbons; PBDEs, polybrominated diphenyl ethers; PCBs, polychlorinated biphenyls; TEQ, Toxicity EQuivalent]

\begin{tabular}{|c|c|c|}
\hline Chemical & $\begin{array}{l}\text { Percent variation explained } \\
\qquad\left(r^{2} \times 100\right)\end{array}$ & $\begin{array}{l}\text { Significant selected predictor variable (associated } \\
\text { parameter estimate, in percent) }\end{array}$ \\
\hline \multicolumn{3}{|c|}{ Total for organics } \\
\hline Total PCBs & 0.13 & Urban in watershed $(0.030)$ \\
\hline Total of 12 most toxic PCBs & 0.14 & Urban in watershed $(0.035)$ \\
\hline TEQ-PCB & 0.24 & Sand $(-0.05)$ \\
\hline Total PBDEs & 0.46 & Clay $(0.22)$ \\
\hline Total PAHs & 0.38 & Clay $(0.21)$ \\
\hline \multicolumn{3}{|c|}{ Specific PAHs } \\
\hline $\operatorname{Benzo}(g, h, i)$ perylene & 0.33 & Clay $(0.20)$ \\
\hline Benz $[a]$ anthracene & 0.32 & Clay $(0.27)$ \\
\hline Chrysene & 0.36 & Clay $(0.62)$ \\
\hline Fluoranthene & 0.34 & Clay $(0.055)$ \\
\hline Pyrene & 0.33 & Clay $(0.24)$ \\
\hline \multicolumn{3}{|c|}{ Metals } \\
\hline Arsenic & 0.23 & Clay $(0.052)$ \\
\hline Cadmium & 0.30 & Sand $(-0.027)$ \\
\hline Chromium & 0.35 & Clay $(0.032)$, shoreline urban $(-0.005)$ \\
\hline Copper & 0.58 & Clay $(0.074)$, shoreline urban $(0.009)$ \\
\hline Lead & 0.26 & Urban in watershed $(0.021)$ \\
\hline Mercury & 0.33 & Clay $(0.071)$, agriculture in watershed $(-0.034)$ \\
\hline Nickel & 0.20 & Shoreline urban $(-0.006)$ \\
\hline Tin & 0.20 & Shoreline urban (0.015) \\
\hline Zinc & 0.52 & Clay $(0.046)$, shoreline urban $(0.007)$ \\
\hline
\end{tabular}




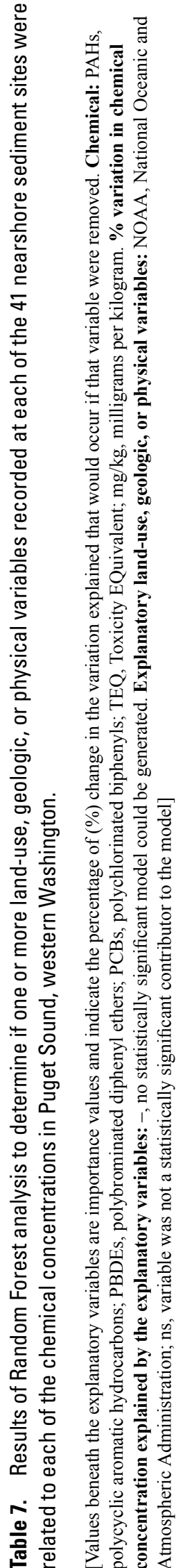

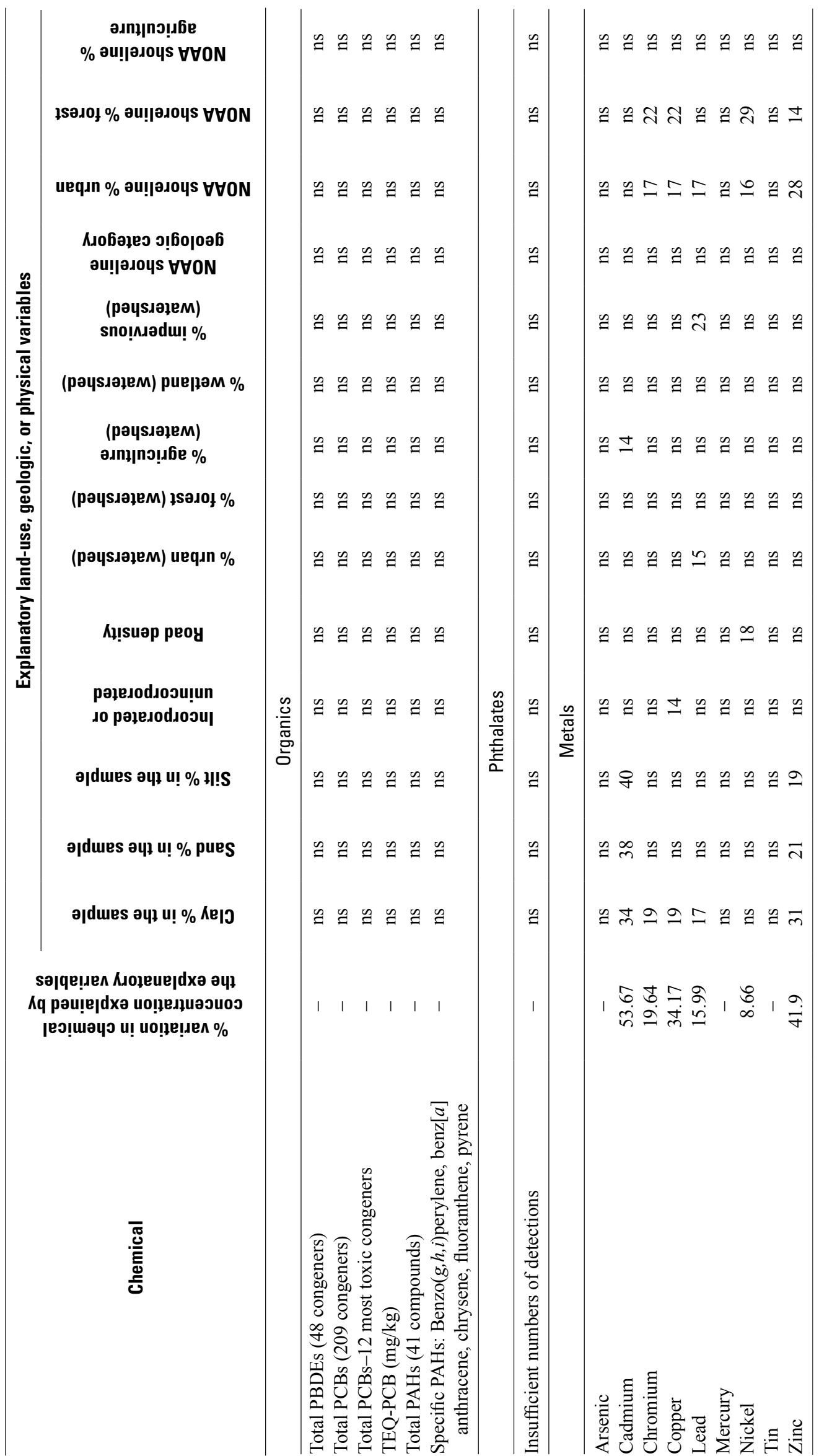




\section{Effects of Marine Hydrodynamics on Sediment Quality}

Unlike the land-use and geologic variables examined, the type of drift cell in which a site was located had a significant effect on sediment chemical concentrations. The five drift cells considered were (1) Divergence Zone (Divergent), (2) Right to Left (Right), (3) Left to Right (Left), (4) No Appreciable Drift (None), and (5) Undefined. Each of these drift cells are uniquely characterized based on their transport of sediment. For example, Right to Left and Left to Right drift cells have greater and more consistent energy capable of moving and re-sorting nearshore sediment than a No Appreciable Drift (None) zone. A Divergence Zone has intermediate and less consistent energy than either the Right to Left or Left to Right drift cells.

For total PCBs, total PBDEs, and total PAHs, sites located in drift cells characterized as None and Undefined had significantly higher concentrations than those sites located in drift cells characterized as Right or Left (fig. 13). The sites characterized as Undefined included sites that were somewhat confined by natural or man-made features. The sites located in Divergent cells often had concentrations of intermediate values. The 15 PAHs with Washington State sediment criteria indicated a similar drift cell pattern as the totals presented in figure 13. For all PAHs but acenaphthene, sediment chemical concentrations were significantly higher at sites located within drift cells characterized as None or Undefined. Drift cells characterized as either Right or Left were never significantly different from each other (table 8). In other words, drift cells with defined directional flows and more constant transport energy have lower organic chemical sediment concentrations than drift cells with limited sediment transport.

Like the concentrations of organics, concentrations of metals often were significantly higher at sites within the None and Undefined drift cells when compared to Left or Right cells (fig. 14). The exceptions were cadmium and chromium, which showed no statistical difference between drift cells; however, the highest concentrations for these compounds were present at sites within the drift cells identified as None. The metals also showed more variation in terms of drift cell differences than the organics.

Table 8. Results of statistical tests to determine if sediment polycyclic aromatic hydrocarbon concentrations are significantly different between drift cell types.

[A Kruskal-Wallis test was used to determine if there was a significant difference between drift cells for each PAH. For those PAH with censored values, the modified Kruskal-Wallis test as described in Helsel (2005) was used. A Conover-Inman pairwise test was used to determine the significant difference between each drift cell type for each PAH. For each PAH, drift cells are ordered from the highest to lowest mean concentration. Those drift cells with different letters are significantly different at the $\mathrm{p}=0.05$ level. PAH: polycyclic aromatic hydrocarbon. p-value: $<$, less than. Drift Cells ranked from highest to lowest mean concentrations by chemical: None, No Appreciable Drift; Right, Right to Left; Left, Left to Right; Divergent, Divergence Zone; -, the Kruskal-Wallis test was not significant]

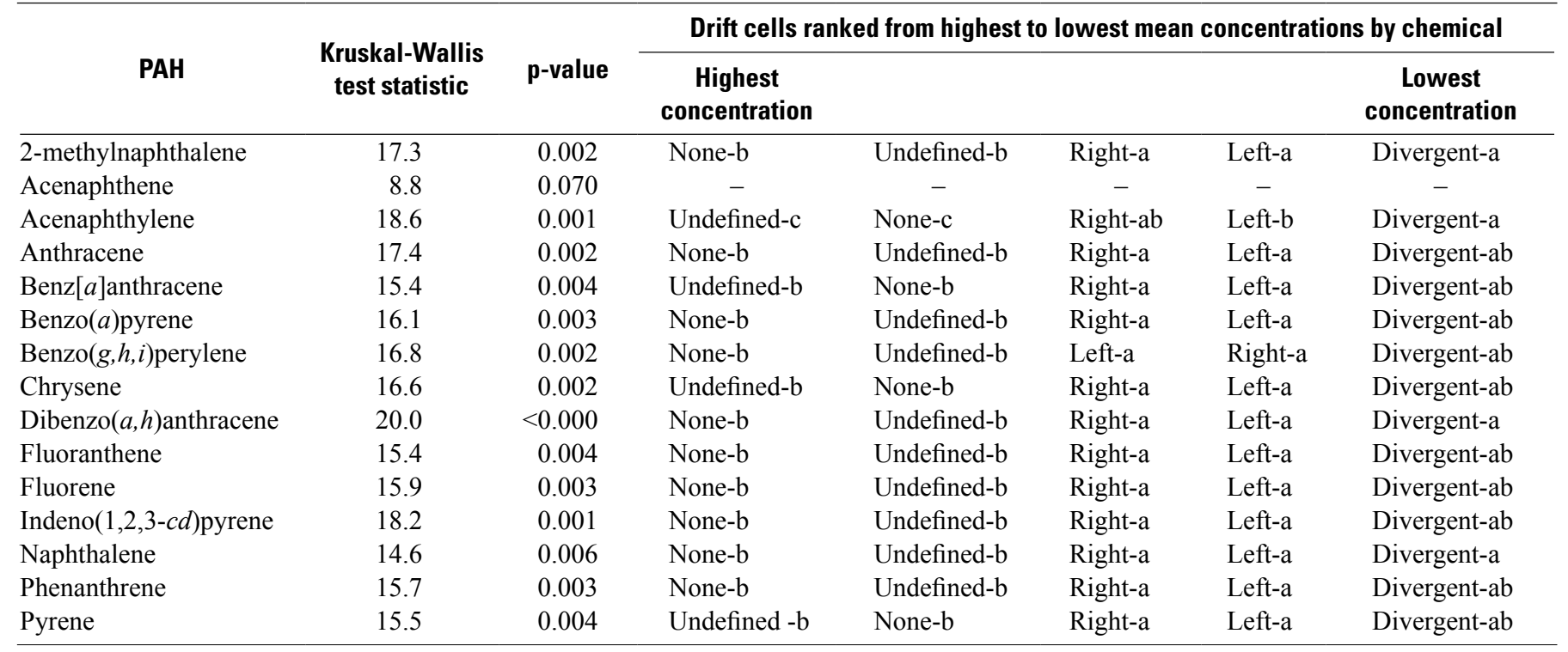



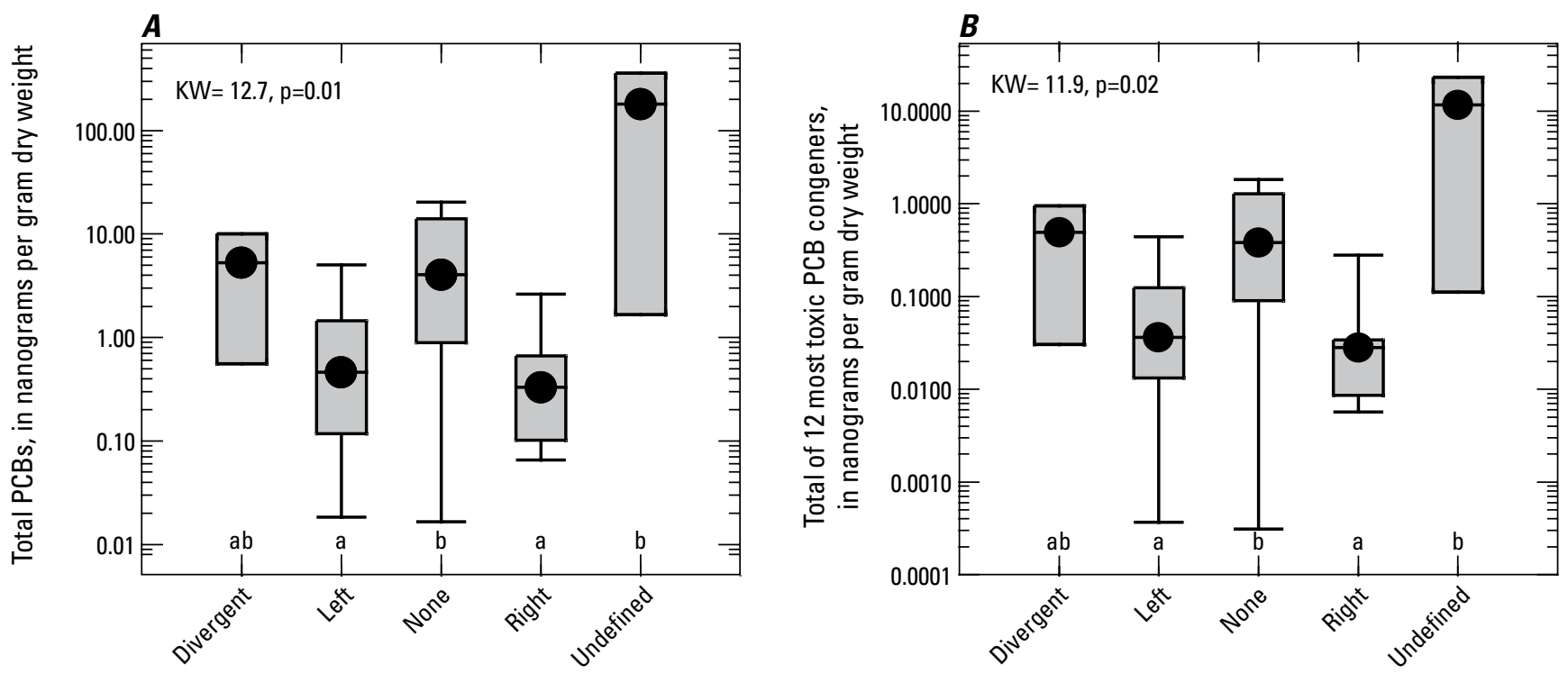

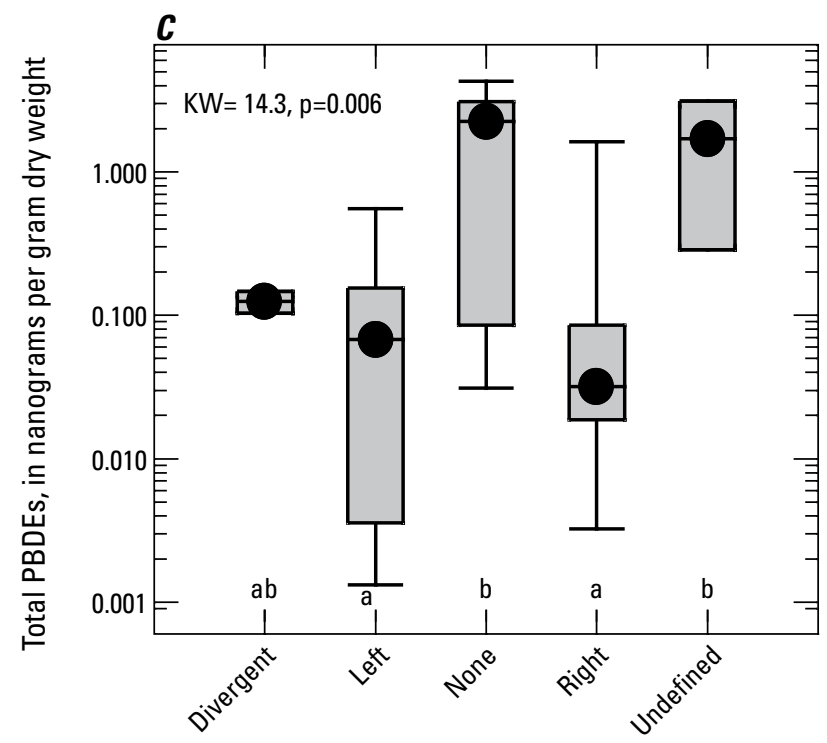

Drift cell type

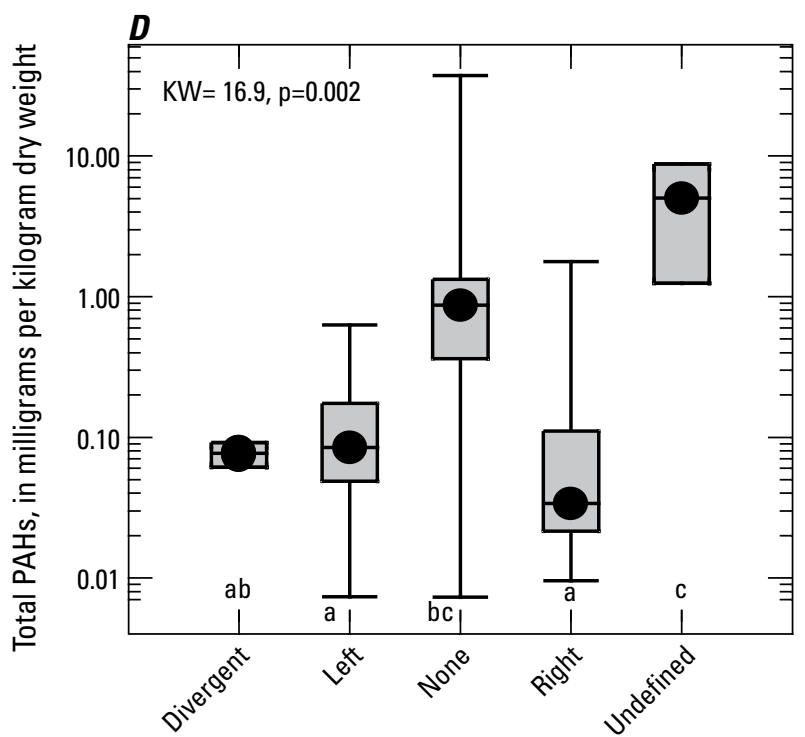

Drift cell type

\section{EXPLANATION}

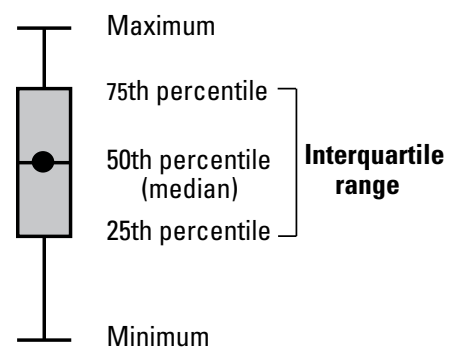

Figure 13. Concentrations of total polychlorinated biphenyls (PCBs; 209 congeners) $(A)$, total of the 12 most toxic PCB congeners $(B)$, total polybrominated diphenyl ethers (PBDEs; 48 congeners) $(C)$, and total polycyclic aromatic hydrocarbons (PAHs; 42 compounds) (D), compared to drift cell types, Puget Sound, western Washington. Left, Left to Right drift cell; Right, Right to Left drift cell; KW, Kruskal-Wallis test statistic; p, p-value for the KW test statistic. For each compound, those drift cell types with different letters are significantly different from each other based on Conover-Inman post-hoc pairwise comparison tests. 

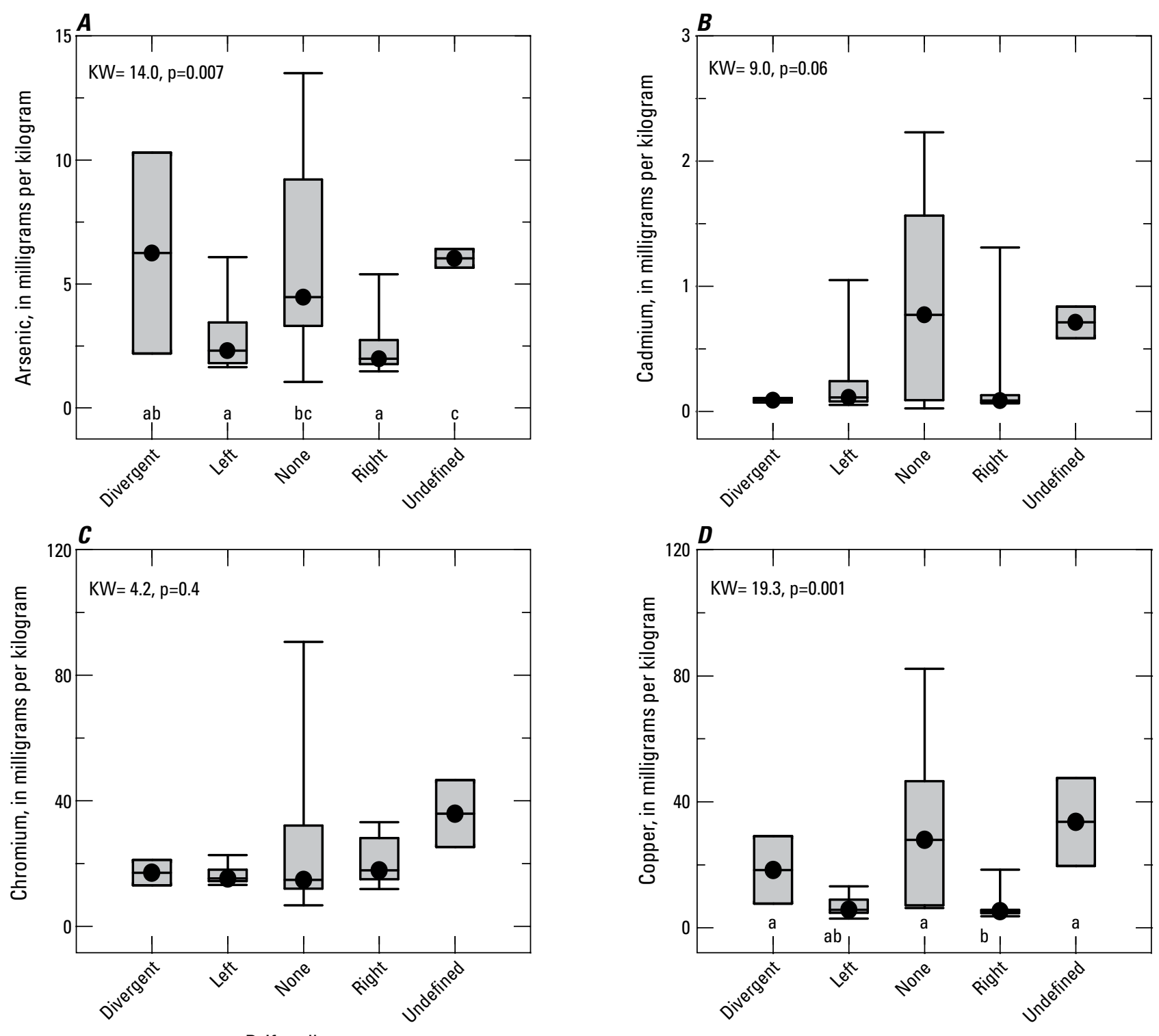

Drift cell type

Drift cell type

EXPLANATION

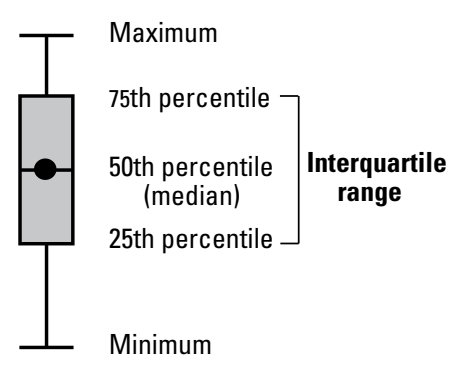

Figure 14. Concentrations of $\operatorname{arsenic}(A)$, cadmium $(B)$, chromium $(C)$, copper $(D)$, lead $(E)$, mercury $(F)$, and zinc $(G)$ compared to drift cell types, Puget Sound, western Washington. Left, Left to Right drift cell; Right, Right to Left drift cell; KW, Kruskal-Wallis test statistic; p, p-value for the KW test statistic. For each compound, those drift cell types with different letters are significantly different from each other based on Conover-Inman post-hoc pairwise comparison tests. 

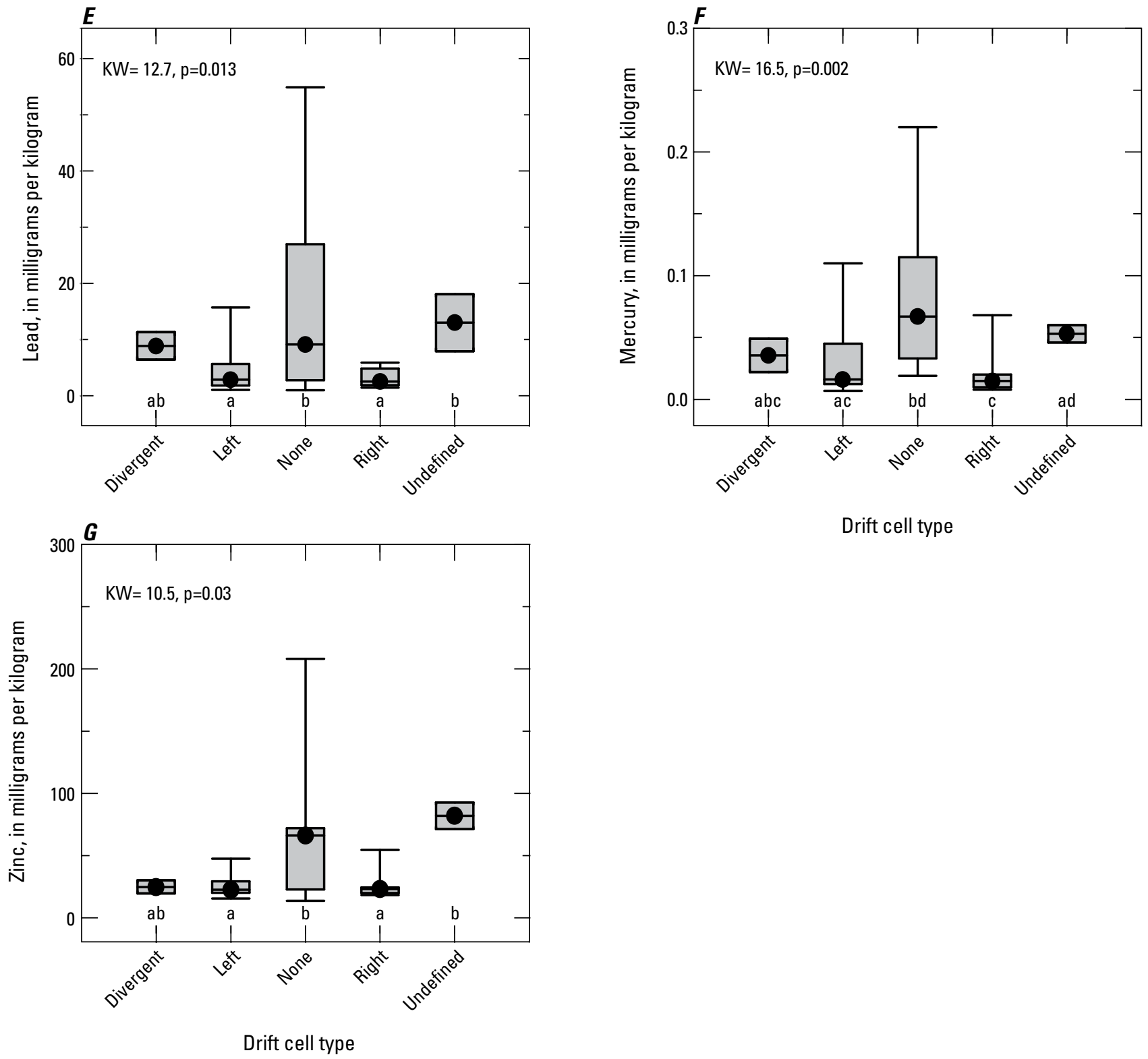

Drift cell type

Figure 14. Continued. 


\section{Sediment Compared to Mussel Tissue Concentrations}

As noted in section, "Comparison with Mussel and Other Sediment Results," 31 of the 41 nearshore sediment sampling sites were collocated with SAM mussel sites in which tissue samples were analyzed for many of the same chemicals (Lanksbury and others, 2017). The sediment and mussel chemical concentrations were graphically compared for the collocated sites for total PCBs, total PAHs, arsenic, cadmium, copper, lead, mercury, and zinc. Graphs of total PCBs and total PAHs are shown in figure 15. Although a preliminary examination of these graphs suggests that elevated concentrations of total PCBs and PAHs (both TOC-normalized) may be related to elevated concentrations of these compounds in mussel tissue, mussel tissue concentrations varied greatly when sediment concentrations were high. Traditional linear and nonlinear statistical tests did not indicate any significant relation based on the data presented in these figures. For metals, there were no obvious relations between sediment and mussel metal concentrations (fig. 16). Compared to sediment metal concentrations, mussel metal concentrations generally were lower and had smaller variation.

\section{Nearshore Sediment Compared to Other Sediment Sampling Programs}

Although the SAM nearshore sediment sampling is unique in its focus on the urban nearshore in Washington State, Ecology has had a long-term marine sediment monitoring program known as PSEMP. To place the SAM nearshore sediment results in some context with the long-term program, comparisons of the results of these two programs are presented in tables 3 and 5, and in the figures and table that follow. These two programs have different study goals, methods, and sampling locations; their primary similarity is the fact that they are sampling similar sediment chemical concentrations in surficial marine sediments. However, the PSEMP samples generally are collected from much deeper locations than the SAM samples. Given the differences between these two programs, much care was taken in comparing results from these programs, and these results should be viewed as exploratory.

It is well known that sediment grain size has an influence on chemical concentrations (Ackermann and others, 1983; Tetra Tech Inc., 1986; Shelton and Capel, 1994; Chapman and Mann, 1999). Sediment that is finer than $2 \mathrm{~mm}$ in diameter typically has higher chemical concentrations than sediment with larger particle diameters. To address this issue prior to examining sediment concentrations, sediment sizes were compared between these two programs. For the SAM nearshore sediment work, all samples were sieved in the field to less than $2 \mathrm{~mm}$ in diameter, which removed all particles greater than this prior to chemical analysis. Although not sieved, most (94 percent) of the PSEMP samples were each composed of grains more than 90 percent of which were less than $2 \mathrm{~mm}$ in diameter. Although both sediment sampling programs primarily were composed of sediment less than $2 \mathrm{~mm}$ in diameter, the PSEMP samples were composed of smaller particle sizes than the SAM nearshore samples (fig. 17).

For total PCBs, PBDEs, and PAHs, the congeners and chemicals analyzed for the two programs varied. Therefore, before any comparisons were made, only those congeners and compounds used in both programs were used to generate total values for these three groups of chemicals. All chemical comparisons were done for non-normalized values. The data used for the PSEMP values included data from 2002 to 2014.

\section{Organic Compound Comparisons}

The concentrations for total PCBs, PBDEs, and PAHs are compared in figure 18. For total PCBs, minimum and mean values for the nearshore sites were lower than the PSEMP sites. However, the maximum total PCB concentration at one of the nearshore sites was greater than the highest PSEMP concentration. For total PBDEs, the nearshore minimum, mean and maximum concentrations were lower than those at the PSEMP sites. The total PAH concentrations at the nearshore sites were generally higher than the PSEMP sites for the minimum, mean, and maximum values.

\section{Individual Polycyclic Aromatic Hydrocarbons}

Concentrations of individual PAH compounds, collected as part of the SAM nearshore and PSEMP programs, compared to Washington State sediment criteria PSEMP are presented in table 3 . As with the comparison with total PAHs, many of the maximum values measured as part of the nearshore study were greater than the maximum values measured by the PSEMP study. Of the 15 individual PAH compounds considered, 9 of the mean concentrations at the nearshore sites were greater than the PSEMP mean concentrations. Many of the minimum values for both programs were less than detection limits.

\section{Metals}

A comparison of metal concentrations measured as part of the SAM nearshore and PSEMP programs is presented in table 5. The PSEMP concentrations generally were higher for all the metals except tin, which had higher concentrations for the minimum, mean, and maximum values. The minimum arsenic concentration measured in the nearshore program was slightly higher than the minimum arsenic concentration for the PSEMP program. 

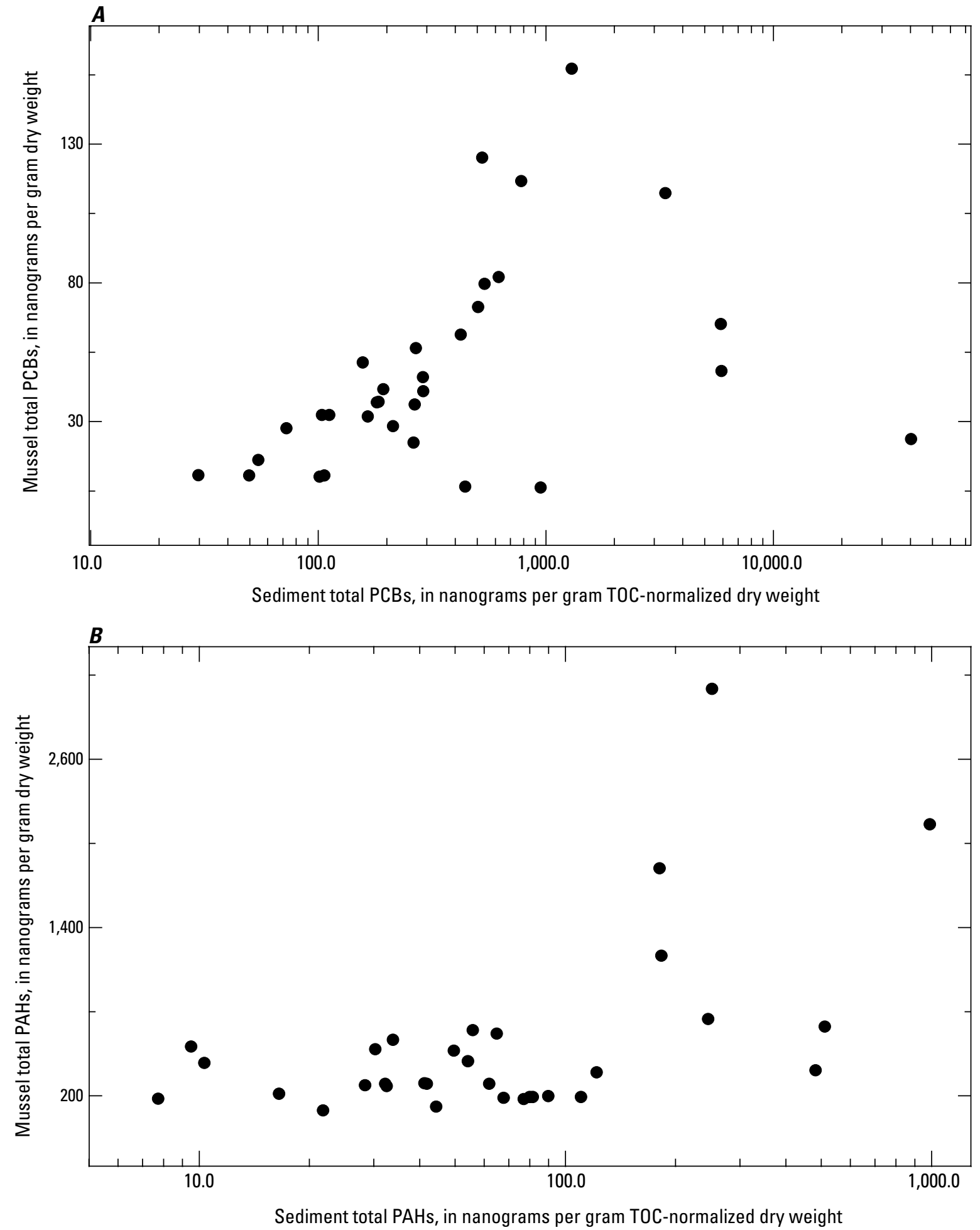

Figure 15. Concentrations of total polychlorinated biphenyls $(\mathrm{PCBs})(A)$, and total polycyclic aromatic hydrocarbons (PAHs) $(B)$ in sediment compared to total PCBs and PAHs, respectively, in mussel tissue, Puget Sound, western Washington. Mussel tissues were obtained from caged mussels deployed near the locations in which sediment was collected. Mussel tissues were obtained about 6 months prior to the collection of nearshore sediment samples. All concentrations were total carbon concentration (TOC)-normalized. 


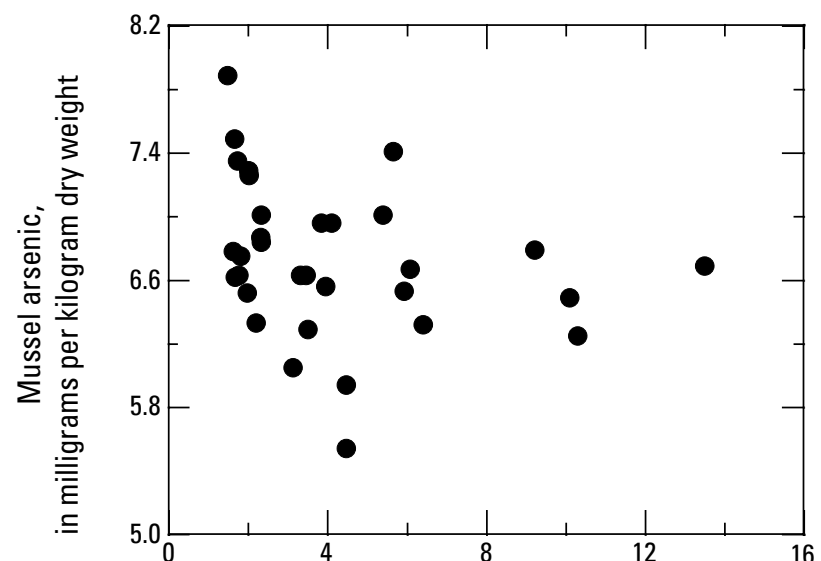

Sediment arsenic, in milligrams per kilogram dry weight

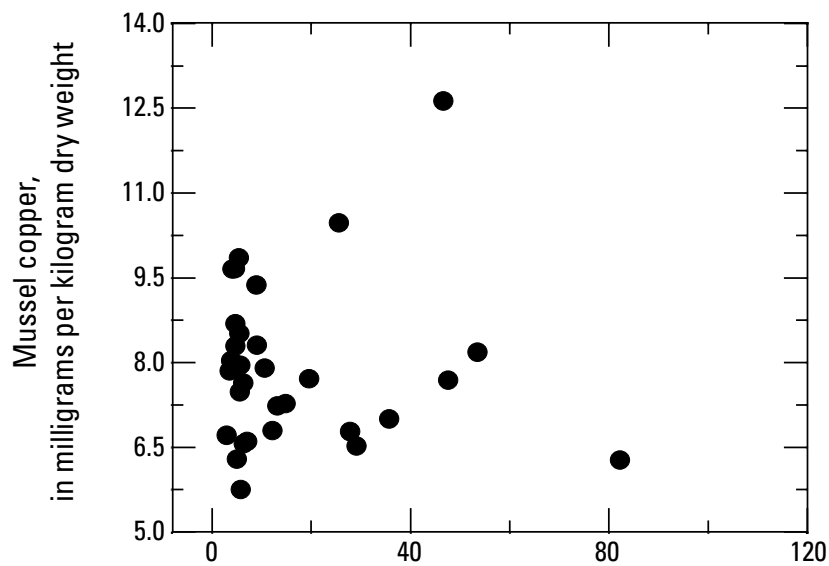

Sediment copper, in milligrams per kilogram dry weight

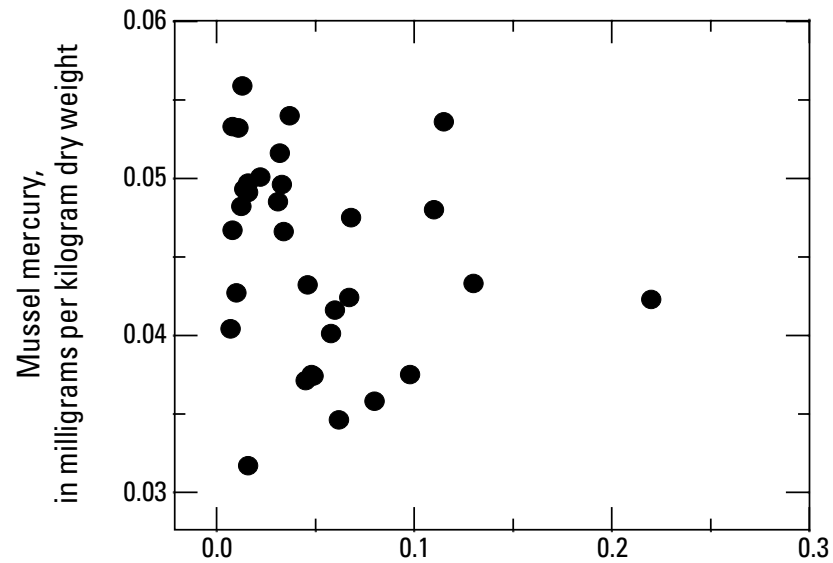

Sediment mercury, in milligrams per kilogram dry weight

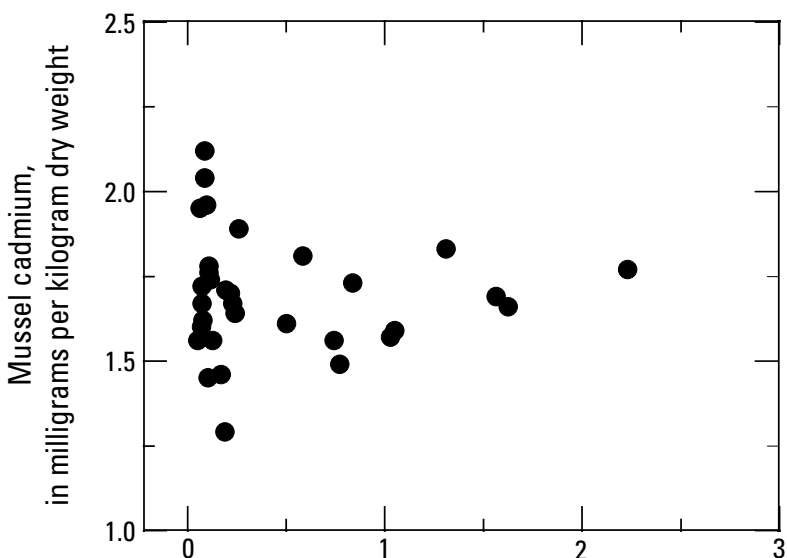

Sediment cadmium, in milligrams per kilogram dry weight

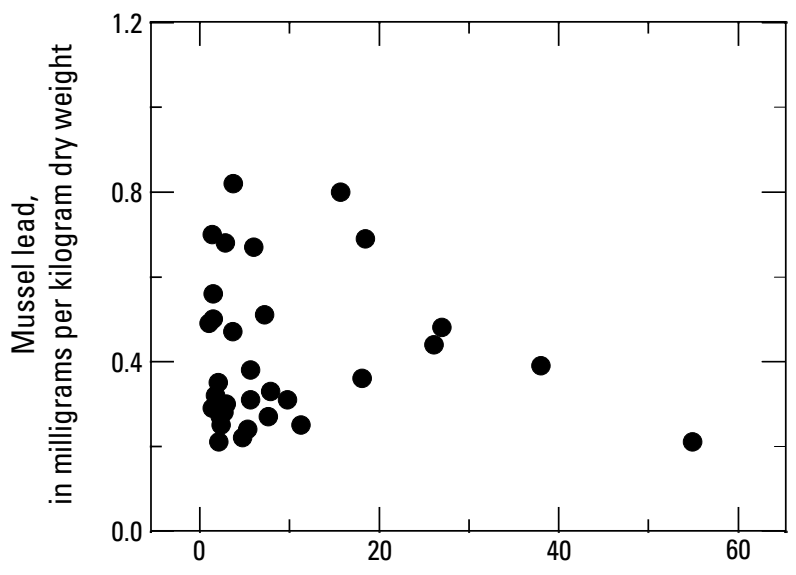

Sediment lead, in milligrams per kilogram dry weight

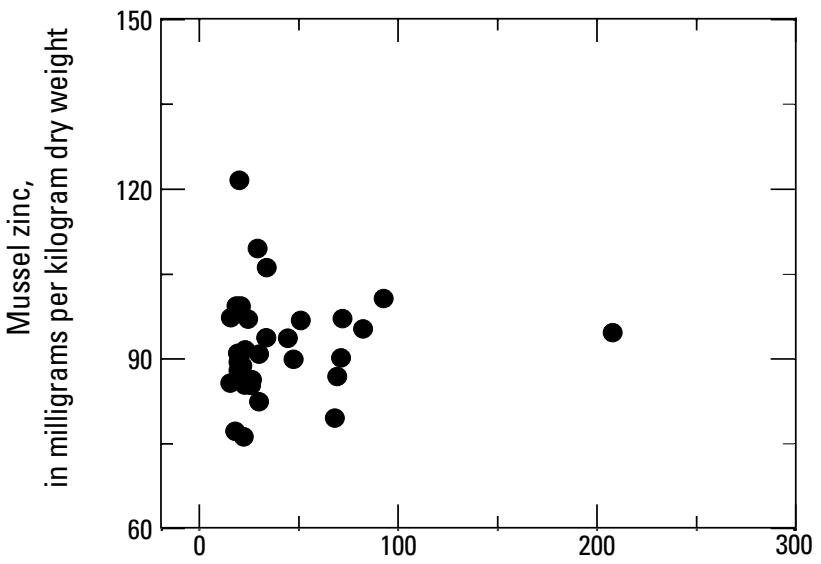

Sediment zinc, in milligrams per kilogram dry weight

Figure 16. Metal concentrations in sediment compared to metal concentrations in mussel tissue, Puget Sound, western Washington. Mussel tissues were obtained from caged mussels deployed near the locations in which sediment was collected. Mussel tissues were obtained about 6 months prior to the collection of nearshore sediment samples. All concentrations were total carbon concentration-normalized. 

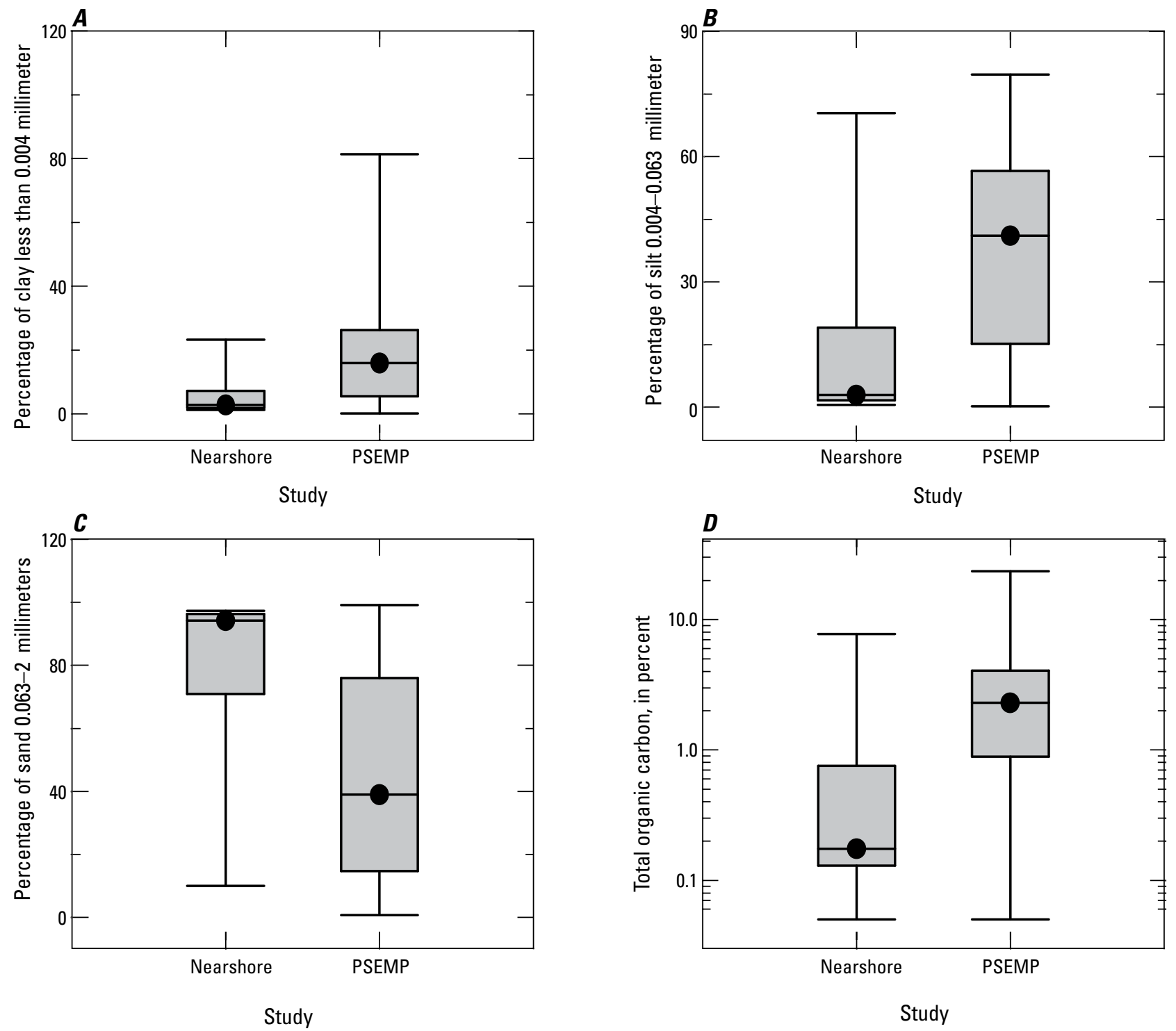

\section{EXPLANATION}

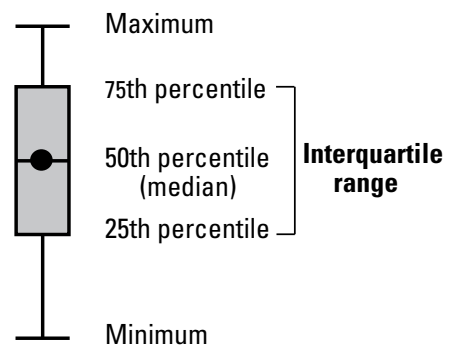

Figure 17. Percentage of sediment sample composed of small particles of clay $(A)$, silt $(B)$, and sand $(C)$, and total organic carbon (D) from the Stormwater Action Monitoring nearshore study, 2016, and the Puget Sound Ecosystem Monitoring Program (PSEMP), Puget Sound, western Washington, 2002-14. 

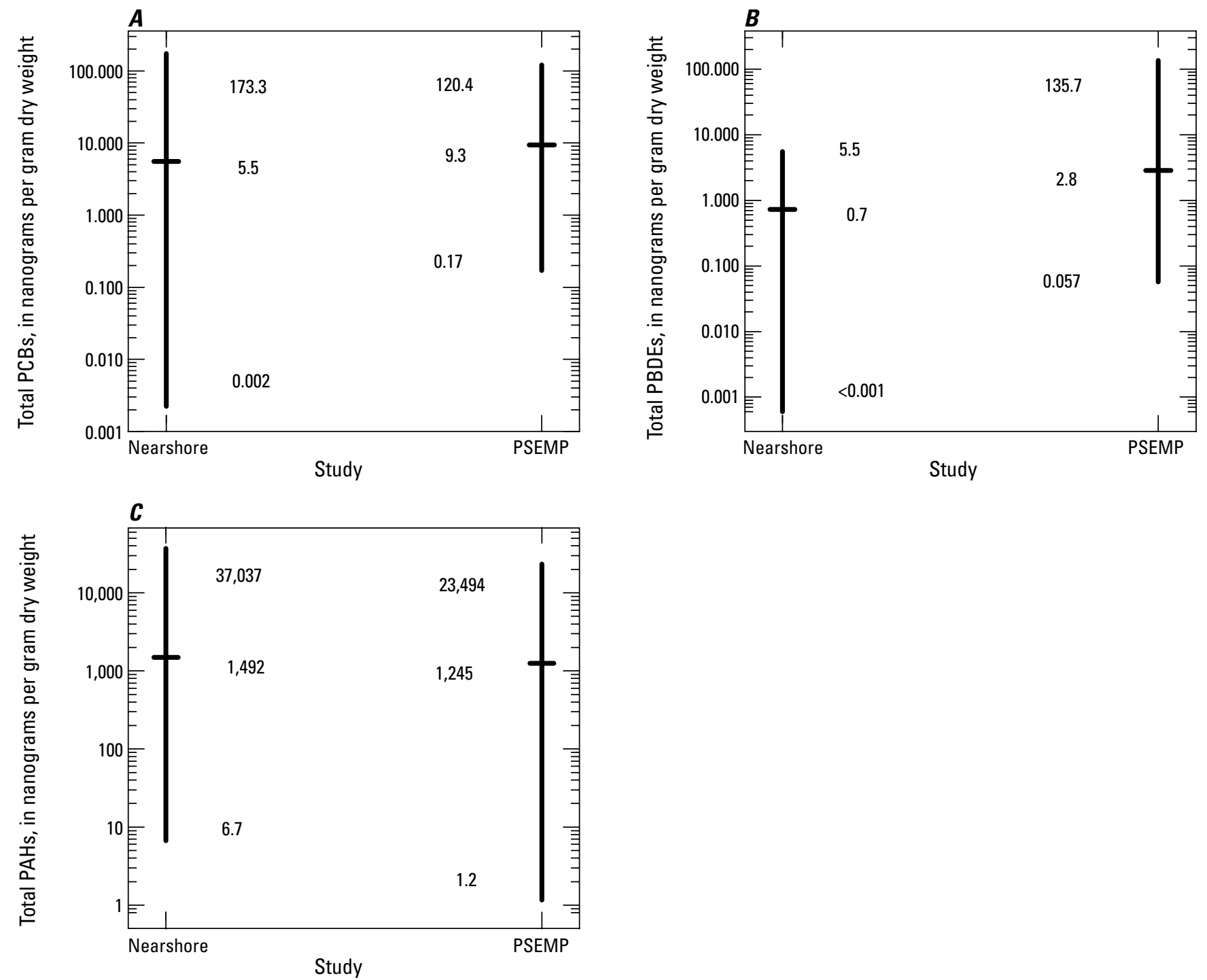

Figure 18. Concentrations of total polychlorinated biphenyls (PCBs) (A), total polybrominated diphenyl ethers (PBDEs) $(B)$, and total polycyclic aromatic hydrocarbons (PAHs) $(C)$ in sediment sampled for the Stormwater Action Monitoring nearshore study, 2016, and the Puget Sound Ecosystem Monitoring Program (PSEMP), Puget Sound, western Washington, 2002-14. Concentration values shown are the maximum (top of black vertical lines), mean (horizontal black lines), and minimum (bottom of black vertical lines) values. 


\section{Microplastics in the Nearshore Sediment}

Microplastics were detected in the nearshore sediments collected as part of the SAM sediment sampling effort at 25 of the 41 sites, representing a range of land cover and all the drift cell types. Samples were characterized as either fiber or nonfiber within two size classes $(>1,000 \mu \mathrm{m}$ and $355-1,000 \mu \mathrm{m}$; table 9). Total microplastic concentrations ranged from 0.022 to 0.654 pieces per gram of dry sediment, with a mean of 0.19 pieces per gram of dry sediment. The concentration of all fibers ranged from about 0.02 to 0.48 pieces per gram, with a mean of 0.15 pieces per gram, and was higher than the range and mean for non-fiber pieces (about $0-0.38$ pieces per gram, mean 0.04 pieces per gram). The abundance of all fibers was more than 270 percent higher than non-fibers. Small microplastic pieces between 355 and $1,000 \mu \mathrm{m}$ were more than 300 percent more abundant than pieces greater than $1,000 \mu \mathrm{m}$. For both the small and large size classes evaluated, fibers dominated the microplastics sample by an order of magnitude more than non-fiber plastics (table 9). The microplastic results are presented in terms of drift cells in figure 19. Although plastics were collected from all drift cell types, the microplastics results in figure 19 combined Left to Right and Right to Left drift cells into "Left" or "Right" and Undefined and None into "None." Although included in figure 19, the Divergent drift cell results were excluded from any statistical analysis because only two samples were available. Although there were no significant differences between microplastic densities at sites located in any of the drift cells characterized, non-fiber pieces were higher in the lower-energy drift cells characterized as None than those in the higher energy drift cells characterized as Left or Right. The median densities of small and large fibers also were determined to be higher at sites in drift cells characterized as None than those characterized as Left or Right, but the variation and maximum densities of fibers generally were higher at sites located in drift cell characterized as Left or Right when compared to those characterized as None (fig. 19). Like the chemical concentrations in sediment, the number of plastic particles in sediment also was poorly related to land cover. These findings should be evaluated with care, given the preliminary nature of microplastic sample collection and laboratory analysis methods.

Table 9. Number of plastic particles per gram of sediment by site, size category and type.

[See table 1 and figure 2 for locations of sites sampled. Size category and plastic type: >, greater than; $\mu \mathrm{m}$, micrometer; -, no plastics detected in this size category]

\begin{tabular}{|c|c|c|c|c|c|c|c|}
\hline \multirow{2}{*}{$\begin{array}{l}\text { Site } \\
\text { No. }\end{array}$} & \multicolumn{4}{|c|}{ Size category and plastic type } & \multicolumn{3}{|c|}{ Plastic type } \\
\hline & Fibers & Non-fibers & Fibers & Non-fibers & $\begin{array}{l}\text { Total } \\
\text { fibers }\end{array}$ & $\begin{array}{c}\text { Total } \\
\text { non-fibers }\end{array}$ & $\begin{array}{c}\text { Total (fibers } \\
\text { and non-fibers) }\end{array}$ \\
\hline 1 & 0 & 0 & 0.039 & 0 & 0.039 & 0 & 0.039 \\
\hline 11 & 0.371 & 0.202 & 0 & 0 & 0.371 & 0.202 & 0.573 \\
\hline 13 & 0.022 & 0 & 0 & 0 & 0.022 & 0 & 0.022 \\
\hline 17 & 0.479 & 0.067 & - & - & 0.479 & 0.067 & 0.546 \\
\hline 20 & 0.020 & 0.004 & 0 & 0 & 0.020 & 0.004 & 0.025 \\
\hline 21 & 0.084 & 0.070 & 0.042 & 0.009 & 0.126 & 0.079 & 0.205 \\
\hline 22 & 0.237 & 0.025 & 0.010 & 0 & 0.247 & 0.025 & 0.271 \\
\hline 24 & 0.228 & 0.021 & 0.024 & 0 & 0.251 & 0.021 & 0.272 \\
\hline 30 & 0.180 & 0.368 & 0.098 & 0.008 & 0.278 & 0.376 & 0.654 \\
\hline 31 & 0.147 & 0.017 & 0.008 & 0.004 & 0.155 & 0.021 & 0.176 \\
\hline 33 & 0.098 & 0 & 0 & 0 & 0.098 & 0 & 0.098 \\
\hline 35 & 0.021 & 0.003 & 0.070 & 0.003 & 0.091 & 0.005 & 0.097 \\
\hline 36 & 0.018 & 0.018 & 0.018 & 0 & 0.036 & 0.018 & 0.053 \\
\hline 37 & 0.077 & 0 & 0.016 & 0.008 & 0.093 & 0.008 & 0.101 \\
\hline 38 & 0.321 & 0.026 & 0.005 & 0.003 & 0.326 & 0.028 & 0.354 \\
\hline 40 & 0.026 & 0 & 0.206 & 0 & 0.233 & 0 & 0.233 \\
\hline 42 & 0.009 & 0.007 & 0.013 & 0 & 0.022 & 0.007 & 0.029 \\
\hline 43 & 0.011 & 0.004 & 0.074 & 0.022 & 0.085 & 0.026 & 0.110 \\
\hline 49 & 0.084 & 0.016 & 0 & 0 & 0.084 & 0.016 & 0.099 \\
\hline
\end{tabular}




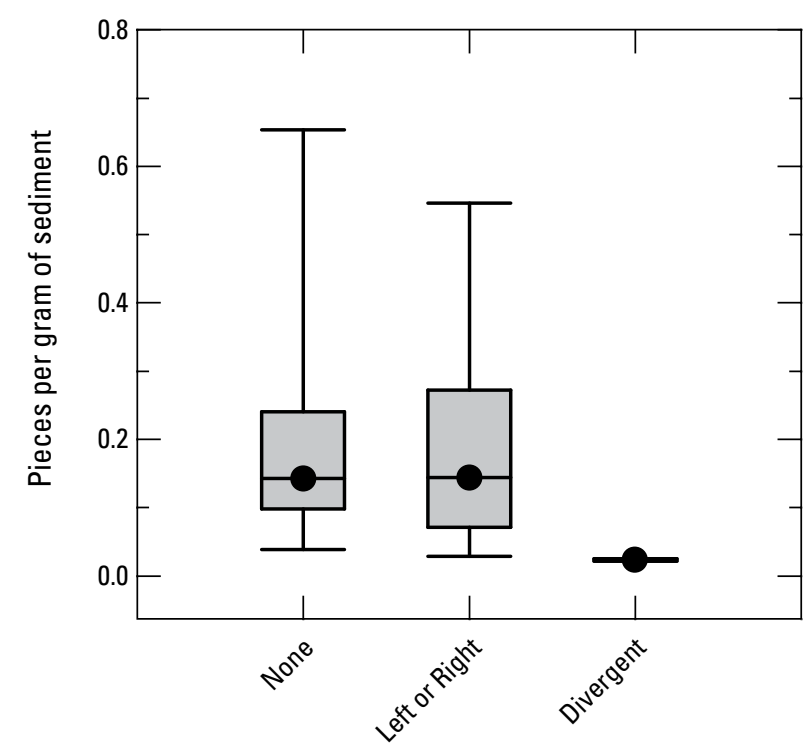

Drift cell type

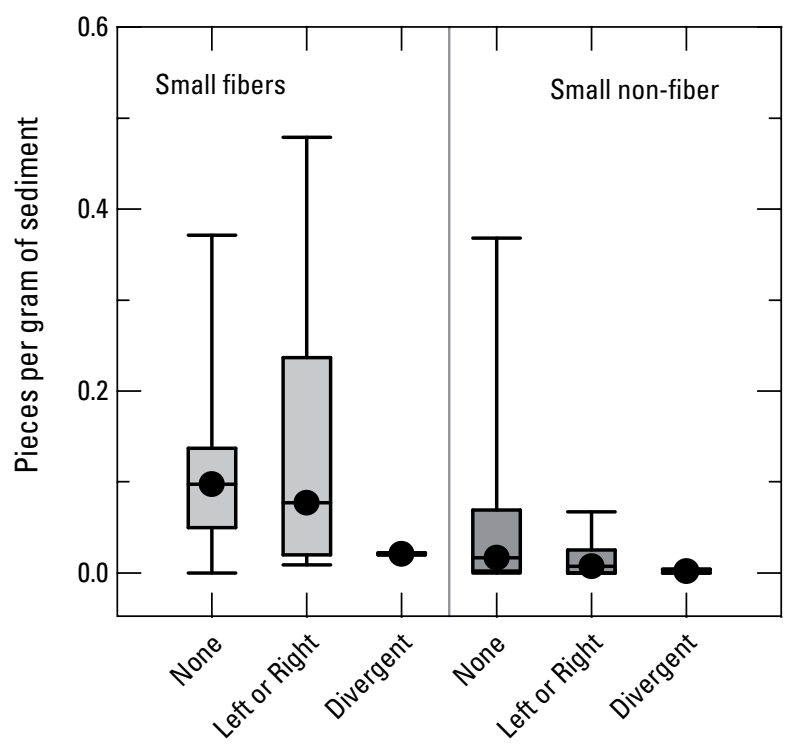

Drift cell type

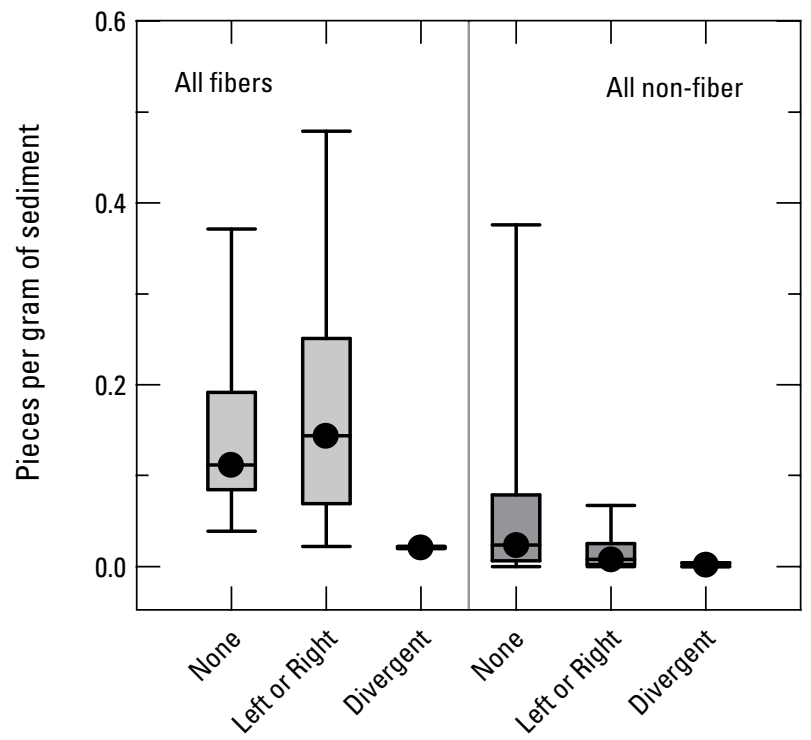

Drift cell type

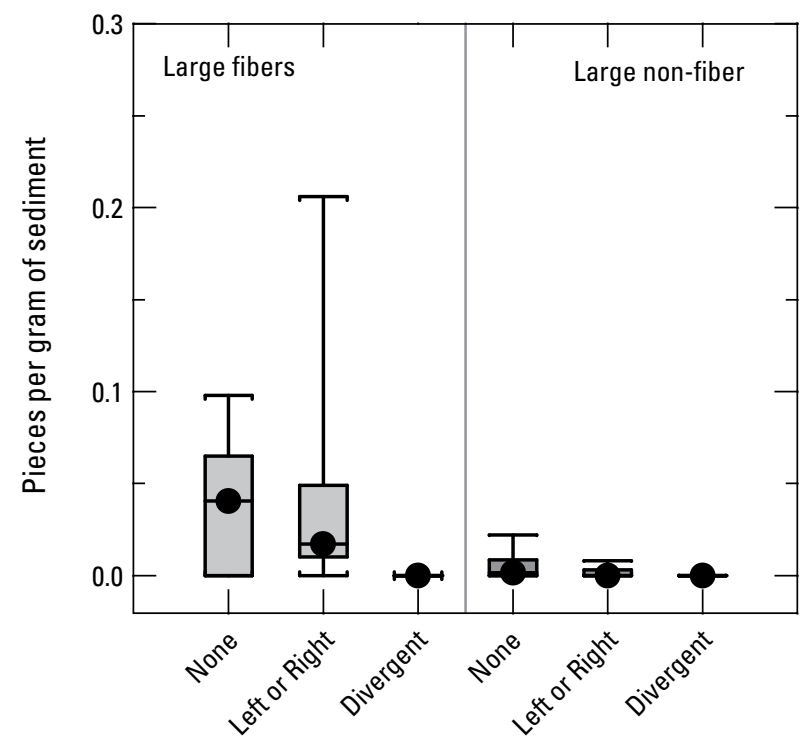

Drift cell type

\section{EXPLANATION}

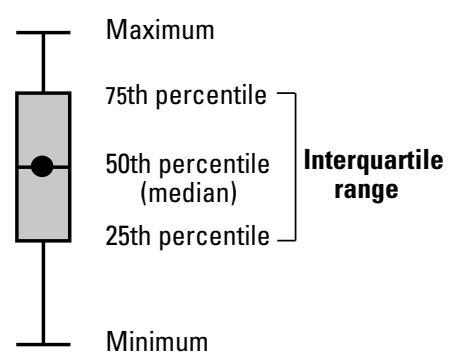

Figure 19. Density of microplastics in nearshore sediments by drift cell and fiber type, and size, Puget Sound, western Washington. None, drift cell types None + Undefined; Left or Right, drift cell types Left to Right + Right to Left; Small fibers and non-fibers, 355-1,000 micrometers; Large fibers and non-fibers, greater than 1,000 micrometers. 


\section{Discussion of Results}

Although the use of many anthropogenic chemicals has been discontinued or is more actively controlled, these chemicals still are present in Puget Sound nearshore sediments. This has contributed to the EPA identifying Puget Sound as an area of concern for adverse biological and ecology effects owing to contaminated sediment (U.S. Environmental Protection Agency, 1997). Organic contaminants such as PCBs, banned since 1979 except for some small allowable uses, are persistent and can remain in sediment and biota (Ross and others, 2000; West and others, 2001, 2008; Long and others, 2005; O'Neill and West, 2009; West, Lanksbury, and O'Neill, 2011; West and others, 2011). Other compounds (such as PAHs, phthalates, PBDEs [recently banned], and metals) continue to enter Puget Sound from point sources, combined sewer outfalls, and non-point sources (such as air deposition, groundwater releases, and stormwater runoff) (Herrera Environmental Consultants, 2011; Hobbs and others, 2015; Milesi, 2015). Many of these compounds enter Puget Sound sorbed to sediments and are deposited in the nearshore environment or are transported by currents in Puget Sound. These compounds are known to have deleterious effects on aquatic resources, and their control and reduction in Puget Sound is the focus of many local, State, and Federal agencies. The overall goal of the work described in this report was to document the spatial extent of urban nearshore sediment health indicated by sediment pollutants and chemical concentrations. Findings from this study could assist the SWG and Ecology in designing a trend study, and about which locations and parameters may be the most useful to include in that study. A nearshore trend study, if pursued further, would support the SWG and Ecology in determining whether NPDES permits issued by the State of Washington are protective of nearshore sediment.

The results of the chemical sediment sampling at the 41 study sites indicated that many of the organic and metal compounds analyzed for were detected at many of the sites, but concentrations generally were low; in most cases, concentrations in more than 96 percent of the UGA nearshore examined were less than established Washington State criteria. Although total PCBs, the sum of all 209 PCB congeners, were detected at every site, 98 percent of the UGA nearshore had concentrations less than a proposed standard (U.S. Environmental Protection Agency, 2014). The single total PCB sample with concentrations greater than the proposed standard was in a depositional area surrounded by light industry and evidence of collapsed piers and unmaintained marine equipment. It had total PCB concentrations of 359.1 and 40,344.7 ng/g (TOC-normalized), which are much greater than the proposed standard of $128 \mathrm{ng} / \mathrm{g}$. Like total PCBs, total PBDEs and PAHs also were detected at every site sampled. However, all these concentrations were low, but could not be compared to any Washington State criteria because none exist.
Individual PAH compounds were detected at all 41 sites, but not usually the same compound, except for benzo $(g, h, i)$ perylene, chrysene, fluoranthene and pyrene, which were detected at all sites sampled. Of the $15 \mathrm{PAH}$ compounds with Washington State marine sediment criteria, 1 site had concentrations greater than the criteria for 10 of the 15 compounds, and a second site had concentrations greater than the criteria for 1 of the 15 compounds (table 2). Although concentrations at some of these sites were greater than Washington State criteria, concentrations at 96 percent or more of the UGA nearshore were less than any established State criteria for individual PAHs.

Most of the phthalates measured as part of this study were rarely observed in the nearshore sediments except for diethyl phthalate, which was measured at 49 percent of the sites. Concentrations of all the phthalates detected were less than the criteria.

Metals generally were detected in varying concentrations at all sites sampled. The exception to this trend was silver, which was only detected at 34 percent of the sampling sites. Although metals were detected at most of the sites, concentrations for all the various metals analyzed were less than the Washington State marine sediment criteria. The characterization of nearshore sediment metal concentrations (such as organic chemicals), sampled in a probabilistic sampling design, suggests that Puget Sound nearshore sediments are relatively clean when compared to the Washington State concentration criteria.

Previous work has identified stormwater as a potential source of organics and metals entering the nearshore environment from surrounding watersheds (Hobbs and others, 2015). A concurrent study examining the concentrations of chemical compounds in introduced mussels reported that organic compounds, PAHs, PCBs, and PBDEs were significantly related to the abundance of urban land cover or impervious surface percentages in the watershed adjacent to the mussel sampling sites (Lanksbury and others, 2017). This study examined similar potential linkages between the concentrations of organics and metals measured in the UGA nearshore sediments and various percentages of land-cover types in the watersheds adjacent to the sampling sites. A finding like the concurrent mussels study finding was not reported for the sediments, even though the land-cover metrics were identical. Organic chemicals in the nearshore sediment generally were weakly related to or statistically unrelated to any of the land-cover metrics examined. For the metals, some of the land-cover metrics (that is, the percentage of shoreline urban and forest land cover) were identified as predictors of sediment concentrations. However, the land-cover metrics explained very little of the variation in measured metal concentrations. Instead, the particle sizes of the samples explained most of the variation in metal concentrations (table 6). 
The lack of or limited relation of the nearshore sediment chemical concentration to the land-cover variables, especially when compared to the results of the mussel study (Lanksbury and others, 2017), can be explained by hydrodynamics and sediment movement along the Puget Sound nearshore. As of 2007, 860 drift cells have been identified throughout Puget Sound (Johannessen and MacLennan, 2007). Each drift cell represents a long-term directional transport of sediment from its source to its depositional zone (Jacobsen and Schwartz, 1981; Johannessen, 1992; Johannessen and MacLennan, 2007). The results of this study indicated a very strong statistical relation between drift cell type and the concentrations of chemicals present in the nearshore sediment. Samples collected within drift cells with documented right to left or left to right transport indicated significantly lower concentrations of total PCBs, PBDEs, PAHs, and most metals as compared to samples collected within drift cells with no transport. These findings suggest that active drift cells are effectively redistributing potentially contaminated sediments from multiple locations within the drift cells and are transporting contaminated sediment offshore, where it is further mixed with deeper marine sediments (Baker, 1984), likely diluting land-use or urbanization effects on sediment chemistry in this study. Drift cells with no transport typically are associated with bays and estuaries where concentrations of sediment contaminants often are elevated. In some cases, drifts cells with no transport often are in areas with active or historic shoreline industrial activities or development. Although some nearshore studies have reported a strong relation between sediment contamination and levels of shoreline urbanization (Pinedo and others, 2014), the coastal currents in these studies are substantially lower than those in Puget Sound. The Puget Sound nearshore and its associated drift cells are largely influenced by high energy conditions such as windstorms that act on beaches and bluffs. As a result, during periods of low wave energy (that is, late summer), nearshore sediment can represent a storm artifact or state of partial recovery rather than an equilibrium (Nordstrom, 1992; Finlayson, 2006).

The source of sediment for most of these drift cells is dominated by bluffs of glacial drift. Puget Sound beaches and nearshore sediment are composed primarily of sediment derived from bluff erosion (Keuler, 1988). Therefore, the chemical composition of the sediment in the bluffs themselves is an important factor in the chemical characteristics of the nearshore sediment; this may be particularly important in terms of metal concentrations in bluffs. The bluff deposits are transported along the drift cells where they are mixed with stormwater-derived sediments and temporarily stored within the drift cell, moved offshore, or deposited in a depositional zone at the end of a drift cell (Wallace, 1988).

The presence of drift cells and the active transport of nearshore sediment make source tracking of contaminated sediment in Puget Sound a challenge. For example, efforts to remediate nearshore sediment contamination in Ostrich Bay, an arm of Dyes Inlet on Puget Sound, were hampered by the movement and delivery of contaminated sediment throughout the Inlet (Pascoe and others, 2002), making it difficult to determine where the contaminated sediment was coming from. Although this study documents a strong relation between drift cells and sediment chemistry, additional unknowns add to the complex dynamics influencing sediment movement and sediment chemical concentrations. For example, detailed drift cell analyses to determine rates of sediment movement and quantitative sediment budgets are limited (Johannessen and MacLennan, 2007). Furthermore, regions of Puget Sound have different drift cell dynamics that are constantly changing as the morphology of Puget Sound changes. The central Sound has the most active drift cells in terms of sediment movement. The south Sound is the least active, and the north Sound is intermediate. All these dynamics are further altered by shoreline activities such as armoring, bulkhead emplacement, and other physical alterations of the shoreline. Although tissue concentrations of organics in experimentally deployed mussels at the same sites used for this study were determined to be related to land cover (Lanksbury and others, 2017), the dynamic nature of nearshore sediment transport and the active re-sorting of sediment in these environments (Komar, 1976; Keuler, 1979) undoubtedly is diluting and redistributing anthropogenic-derived chemicals throughout Puget Sound. The stationary mussel samples described in Lanksbury and others (2017) likely are integrating anthropogenic chemicals and are representative of local conditions, whereas nearshore sediment chemicals concentrations are more representative of regional conditions.

The study also examined of the abundance of small plastic particles, known as microplastics, at most of the sampling sites that were sampled for chemical analyses. There are no criteria related to microplastics because of their size, abundance, ability to transport sorbed chemicals, potential effects on marine resources, and known stormwater source (Armitage and Rooseboom, 2000); thus, we determined that a preliminary evaluation of microplastic concentrations in the Puget Sound nearshore sediments was appropriate. Like sediments, microplastics can be placed in different size fractions. However, microplastics are composed of numerous types of plastics that have different shapes and densities. These features can have a profound effect on transport and deposition in aquatic environments. Given the diversity in sizes and densities of plastics, it was not surprising to find a wide distribution of microplastic densities across the sites examined in this study. Previous studies have shown that microplastics in sediments tend to settle out more readily in areas of low energy such as bays and harbors (Vianello and others, 2013). Although the median densities of plastics, particularly nonfibers, at sites located in drift cells with no movement were often slightly higher than at sites in actively moving drift cells, the difference was not significant. Microplastic fibers tended to have the greatest range in densities in drift cells characterized as moving from Left to Right or Right to Left, whereas non-fibers consistently had greater density variations 
in drift cells with no movement. These contradictory results seem to highlight the potential variability in microplastic transport based on the shape of microplastics in Puget Sound. Although the study of microplastics in aquatic environments has increased (Ballent and others, 2016), limited nearshore sediment microplastic studies are available. Ballent and others (2016) summarized a large range of microplastic densities in lake and marine beach and nearshore sediments, with a range of $0.0001-5.0$ pieces per gram of sediment. The results of this study indicated a range of $0.02-0.65$ pieces per gram of sediment.

\section{Considerations for Future Nearshore Sediment Work}

The results of this study provide a statistically valid assessment of nearshore sediment chemical conditions throughout Puget Sound in those areas adjacent to the UGA, as defined in 2018. Overall, chemical concentrations generally were less than the Washington State marine sediment criteria throughout the study area. Although the results provide a status assessment of current conditions that can be used to evaluate trends over time assuming the defined UGA boundaries do not change, the use of nearshore sediment sampling - as it was implemented in this study to evaluate stormwater and stormwater management effects - may be limited. The SAM team may want to consider the following observations as they continue to evaluate stormwater management in the Puget Sound Basin:

- A series of analyses was done as part of this study to determine if any of the sediment chemical concentrations were related to any land management, land-use, or geologic designations at multiple scales that are known to influence stormwater dynamics. These analyses generally indicated weak or no relation between any examined land-use designations for any of the organic compounds and showed very limited relation with metals. This was contrary to findings in the SAM mussel study (Lanksbury and others, 2017), which indicated a strong relation between tissue organic concentrations and many land-use features. The lack of or limited relation of the nearshore sediment chemical concentration to the land-use variables examined suggests that nearshore hydrodynamics overwhelm any relation between the land-cover metrics and sediment chemical concentrations; therefore, the current study design is not an appropriate indicator of nearshore sediment chemical concentrations in the UGA. If the goal of nearshore sediment monitoring is to evaluate the status and trends of chemicals in sediment in Puget Sound as a whole, the design used for this study is likely to be appropriate and effective. However, attributing current conditions or measured changes over time to upland activities does not seem possible without a more in-depth understanding of drift cell dynamics.

- If nearshore sediment chemical concentrations are a priority to the SWG, they may want to examine and consider the development of a better characterization of how sediment is transported in the nearshore environment to help address the influence of stormwater inputs on nearshore sediment conditions. A more refined approach for characterizing nearshore water and sediment movement throughout the Sound could not only be helpful in evaluating sediment conditions, but also in addressing effects on water chemistry and biology. However, a Puget Sound-wide nearshore sediment transport assessment is likely to be challenging.

- If nearshore sediment sampling is continued as part of SAM, the program should consider a more stratified random sampling approach for selecting sampling sites to help address the influence of the drift cells on the redistribution of sediment throughout Puget Sound. A more refined designation of sites could reduce the large variability measured in these data. For example, SAM could focus their efforts on nearshore areas within UGA where there are no active drift cells. The inclusion of reference sites in the design also might be effective.

- If sediment sampling is continued, the program should ensure that consistent methods and laboratory procedures are used to facilitate comparisons within and between sediment sampling activities.

- Although most organic contaminants had concentrations less than the Washington State criteria, if SAM continues to sample nearshore sediments, these contaminants should remain on the list of constituents sampled given their known physical and toxicological properties. There are numerous stormwater management-related activities underway designed to reduce toxics in runoff, and the continued sampling for these chemicals might help determine the effectiveness of these activities.

- The phthalate analysis resulted in a large volume of concentration results less than detection limits. Given that phthalates degrade rapidly and their use is rapidly being phased out, the future analysis of these compounds may not be of the highest priority. Future planning efforts may want to include an assessment of the literature to determine the need to sample phthalates in the future. 


\section{Summary}

Although the use of many anthropogenic chemicals has been discontinued, or has been actively controlled, these chemicals still are present in the nearshore sediments of Puget Sound, western Washington. This has contributed to the U.S. Environmental Protection Agency identifying Puget Sound as an area of concern for adverse biological and ecology effects owing to contaminated sediment. Some organic contaminants are persistent and can remain in sediment and biota, while other organics and metals continue to enter Puget Sound from point sources, combined sewer outfalls, and non-point sources such as air deposition, groundwater releases, and stormwater runoff. Many of these compounds enter Puget Sound sorbed to sediments and are deposited in the nearshore environment or are transported by currents in Puget Sound. These compounds are known to have deleterious effects on aquatic resources, and their control and reduction in Puget Sound is the focus of many local, State, and Federal agencies. The overall goal of the work described in this report was to document the spatial extent of urban nearshore sediment health indicated by sediment pollutants and chemical concentrations. Findings from this study could assist agencies and groups such as the Washington State Department of Ecology (Ecology) and the Stormwater Work Group of Puget Sound (SWG) in designing monitoring studies and evaluating nearshore chemical conditions to help evaluate the effectiveness of National Pollutant Discharge Elimination System (NPDES) stormwater permits issued by Ecology.

The results of the chemical sediment sampling at the 41 study sites examined as part of this study indicated that the organic and metal compounds analyzed for were detected at many of the sites, but concentrations generally were low; in most cases, concentrations in more than 96 percent of the Urban Growth Area (UGA) nearshore examined were less than established Washington State criteria. Although at least 1 of the 209 polychlorinated biphenyl (PCB) congeners analyzed for was detected at every site, 98 percent of the nearshore areas adjacent to UGA had concentrations less than a proposed PCB standard. Like PCBs, at least 1 of the 48 polybrominated diphenyl ether (PBDE) congeners and 1 of the 42 polycyclic aromatic hydrocarbon (PAH) compounds analyzed for were detected at every site sampled. However, all these concentrations were low. Of the $15 \mathrm{PAH}$ compounds with Washington State marine sediment criteria, one site had concentrations greater than the criteria for 10 of the 15 compounds, and a second site had concentrations greater than the criteria for 1 of the 15 compounds. Although concentrations at some of these sites were greater than Washington State criteria, concentrations at 96 percent or more of the UGA nearshore were less than any established State criteria for individual PAHs. Most of the six phthalate compounds analyzed for were rarely observed in the nearshore sediments, except for diethyl phthalate, which was measured at 49 percent of the sites. Concentrations of all the phthalates detected were less than the Washington State criteria.
Metals generally were detected in varying concentrations at all sites sampled. The exception to this trend was silver, which was only detected at 34 percent of the sampling sites. Although metals were detected at most of the sites, concentrations for all the various metals analyzed were less than the Washington State marine sediment criteria. The characterization of nearshore sediment metal concentrations (such as organic chemicals), sampled in a probabilistic sampling design, suggests that Puget Sound nearshore sediments are relatively clean when compared to the Washington State concentration criteria.

Using several statistical methods, the results of this study indicated no or very weak relations between nearshore sediment chemical concentrations and various percentages of land-cover types in the watersheds adjacent to the sampling sites. The lack of or limited relation of the chemical concentration to the land-cover variables examined can be explained by hydrodynamics and sediment movement along the Puget Sound nearshore. For each sediment sampling site, the predominant movement of sediment was determined based on published nearshore drift cell designation. Each drift cell represents a segment of the Puget Sound nearshore environment and its long-term directional transport of sediment from its source to its depositional zone. The results of this study indicated a very strong statistical relation between drift cell type and the concentrations of chemicals present in the nearshore sediment. Samples collected within drift cells with active sediment movement characterized as being either Right to Left or Left to Right transport had significantly lower concentrations of total PCBs, PBDEs, PAHs, and most metals as compared to samples collected within drift cells with no transport. Drift cells with no transport typically are associated with bays and estuaries where concentrations of sediment contaminants often are elevated. These findings suggest that active drift cells are effectively redistributing potentially contaminated sediments from multiple locations within the drift cells, diluting land-use or urbanization effects on sediment chemistry. The presence of drift cells and the active transport of nearshore sediment make source tracking of contaminated sediment in Puget Sound a challenge. Although this study documents a strong relation between drift cells and sediment chemistry, additional unknowns add to the complex dynamics influencing sediment movement and sediment chemical concentrations.

The study also examined the abundance of small plastic particles, known as microplastics, at most of the nearshore sediment sampling sites. Microplastics can be identified by their shape and size. For this study, microplastics were identified as being fibers or non-fibers (beads, films, foam, fragments, or line) larger than 1,000 micrometer $(\mu \mathrm{m})$ or from 355 to $1,000 \mu \mathrm{m}$. Results were expressed as numbers of plastic particles per gram of sediment. These physical features can have a profound effect on transport and deposition in aquatic environments. Given the diversity in sizes and densities of plastics, it was not surprising to find a wide distribution of microplastic densities across the sites examined in this study. 
Although the median densities of plastics, particularly nonfibers, at sites located in drift cells with no transport often were slightly higher than at sites in drift cells with active transport, the difference was not significant. Microplastic fibers tended to have the greatest range in densities in drift cells characterized as moving from Left to Right or Right to Left, whereas non-fibers consistently had greater density variations in drift cells with no movement. These contradictory results seem to highlight the potential variability in microplastic transport based on the shape of microplastics in Puget Sound. The results of this study indicated a range of $0.02-0.65$ microplastic pieces per gram of sediment.

The results of this study provide a statistically valid assessment of nearshore sediment chemical conditions throughout Puget Sound in those areas adjacent to the UGA as of 2018. Overall, chemical concentrations generally were less than the Washington State marine sediment criteria throughout the study area. Although the results provide a status assessment of current conditions that can be used to evaluate trends over time, the use of nearshore sediment sampling - as it was implemented in this study to evaluate stormwater and stormwater management effects - may be limited. The Stormwater Action Monitoring (SAM) team may want to consider the following observations as they continue to evaluate stormwater management in the Puget Sound Basin:

1. Nearshore sediment chemical concentrations show very limited relation to land-use features;

2. If nearshore sediment chemical concentrations are a priority to the SAM team, they may want to examine and consider the development of a better characterization of how sediment is transported in the nearshore environment to help address the influence of stormwater inputs on nearshore sediment conditions;

3. If nearshore sediment sampling is continued as part of SAM, the program should consider a more stratified random sampling approach for selecting sampling sites to help address the influence of the drift cells on the redistribution of sediment throughout Puget Sound.

4. If sediment sampling is continued, the program should ensure that consistent methods and laboratory procedures are used to facilitate comparisons within and between sediment sampling activities;

5. Although most organic contaminants had concentrations less than the Washington State criteria, if SAM continues to sample nearshore sediments, these contaminants should remain on the list of constituents sampled given their known physical and toxicological properties; and

6. Given that phthalates degrade rapidly and their use is rapidly being phased out, the future analysis of these compounds may not be of the highest priority.

\section{Acknowledgments}

The authors would like to thank the dedicated field crews from the U.S. Geological Survey Washington Water Science Center, King County and Washington Department of Natural Resources. Joel Bird and Nancy Rosebower (Washington State Department of Ecology Manchester Environmental Laboratory) were instrumental in coordinating and performing laboratory analyses. Colin Elliot's staff at the King County Laboratory also provided invaluable laboratory analyses. Chad Larson (Washington State Department of Ecology) provided help and guidance in the analysis of the probabilistic study design output. The final draft of this report received valuable technical reviews from Wendy Eash-Loucks (King County Department of Natural Resources and Parks) and Keunyea Song (Washington State Department of Ecology). This study would not have been possible without Brandi Lubliner (Washington State Department of Ecology, Stormwater Action Monitoring Coordinator), who effectively coordinated this study selected by the Western Washington Stormwater Permittees through the Stormwater Action Monitoring Program.

\section{References Cited}

Ackermann, F., Bergman, H., and Schleichert, V., 1983, Monitoring of heavy metals in coastal and estuarine sediments - A question of grain size $-20 \mu \mathrm{m}$ versus $<60 \mu \mathrm{m}$ : Environmental Technology Letters, v. 4, no. 7 , p. 317-328, https://doi.org/10.1080/09593338309384212.

Andrady, A.L., 2011, Microplastics in the marine environment: Marine Pollution Bulletin, v. 62, no. 8, p. 1596-1605, https://doi.org/10.1016/j.marpolbul.2011.05.030.

Armitage, N., and Rooseboom, A., 2000, The removal of urban litter from stormwater conduits and streamsPaper 1-The quantities involved and catchment litter management options: Water SA, v. 26, no. 2, p. 181-187.

Ashton, K., Holmes, L., and Turner, A., 2010, Association of metals with plastic production pellets in the marine environment: Marine Pollution Bulletin, v. 60, no. 11, p. 2050-2055, https://doi.org/10.1016/j. marpolbul.2010.07.014.

Baker, E.T., 1984, Patterns of suspended particle distribution and transport in a large fjordlike estuary: Journal of Geophysical Research, v. 89, no. C4, p. 6553-6566, https:// doi.org/10.1029/JC089iC04p06553. 
Ballent, A., Corcoran, P.L., Madden, O., Helm, P.A., and Longstaffe, F.J., 2016, Sources and sinks of microplastics in Canadian Lake Ontario nearshore, tributary and beach sediments: Marine Pollution Bulletin, v. 110 , no. 1 , p. 383-395, https://doi.org/10.1016/j. marpolbul.2016.06.037.

Chapman, P.M., and Mann, G.S., 1999, Sediment quality values (SQVs) and ecological risk assessment (ERA): Marine Pollution Bulletin, v. 38, no. 5, p. 339-344, https:// doi.org/10.1016/S0025-326X(99)00033-8.

Cole, M., Lindeque, P., Halsband, C., and Galloway, T.S., 2011, Microplastics as contaminants in the marine environment - A review: Marine Pollution Bulletin, v. 62 , no. 12, p. 2588-2597, https://doi.org/10.1016/j. marpolbul.2011.09.025.

Cusimano, R., Merritt, G., Plotnikoff, R., Wiseman, C., and Smith, C., 2006, Status and trends monitoring for watershed health and salmon recovery-Quality assurance monitoring plan: Washington State Department of Ecology, Publication No. 06-03-203.

Cutler, D.R., Edwards, T.C., Jr., Beard, K.H., Cutler, A., Hess, K.T., Gibson, J., and Lawler, J.J., 2007, Random forests for classification in ecology: Ecology, v. 88, no. 11, p. 2783-2792, https://doi.org/10.1890/07-0539.1.

Di Toro, D.M., Zarba, C.S., Hansen, D.J., Berry, W.J., Swartz, R.C., Cowan, C.E., Pavlou, S.P., Allen, H.E., Thomas, N.A., and Paquin, P.R., 1991, Technical basis for establishing sediment quality criteria for nonionic organic chemicals using equilibrium partitioning: Environmental Toxicology and Chemistry, v. 10, no. 12, p. 1541-1583, https://doi.org/10.1002/etc.5620101203.

Dutch, M., Partridge, V., Weakland, S., Welch, K., and Long, E., 2009, Quality assurance project plan-The Puget Sound assessment and monitoring program sediment monitoring component: Washington State Department of Ecology Publication No. 09-03-121, 98 p.

Finlayson, D.P., 2006, The geomorphology of Puget Sound beaches: Seattle, University of Washington, School of Oceanography, Ph.D. dissertation, 216 p.

Hamel, N., Joyce, J., Fohn, M., James, A., Toft, J., Lawver, A., Redman, S., and Naughton, M., eds., 2015, 2015 State of the Sound: Puget Sound Partnership, Report on the Puget Sound Vital Signs, 86 p.

Helsel, D.R., 2005, Nondetects and data analysis - Statistics for censored environmental data: New York, Wiley, 250 p.

Herrera Environmental Consultants, Inc., 2011, Control of toxic chemicals in Puget Sound-Phase 3 data and load estimates: Washington State Department of Ecology, Publication No. 11-03-010, 223 p.
Hobbs, W., Lubliner, B., Kale, N., and Newell, E., 2015, Western Washington NPDES Phase 1 stormwater permitFinal data characterization 2009-2013: Washington State Department of Ecology, Publication No. 15-03-001, 152 p.

Homer, C.G., Dewitz, J.A., Yang, L., Jin, S., Danielson, P., Xian, G., Coulston, J., Herold, N.D., Wickham, J.D., and Megown, K., 2015, Completion of the 2011 National Land Cover Database for the conterminous United StatesRepresenting a decade of land cover change information: Photogrammetric Engineering and Remote Sensing, v. 81, no. 5, p. 345-354.

Jacobsen, E.E., and Schwartz, M.L., 1981, The use of geomorphic indicators to determine the direction of net shore-drift: Shore and Beach, v. 49, p. 38-42.

Johannessen, J.W., 1992, Net shore-drift in San Juan County and parts of Jefferson, Island, and Snohomish counties, Washington-Final report: Prepared by Western Washington University for Shorelands and Coastal Zone Management Program, Washington State Department of Ecology, Olympia, 58 p. plus 25 maps.

Johannessen, J., and MacLennan, A., 2007, Beaches and bluffs of Puget Sound: U.S. Army Corps of Engineers, Seattle District, Puget Sound Nearshore Partnership Report No. 2007-04, 27 p.

Keuler, R.F., 1979, Coastal zone processes and geomorphology of Skagit County, Washington: Bellingham, Western Washington University, Master's thesis, 123 p.

Keuler, R.F., 1988, Map showing coastal erosion, sediment supply, and longshore transport in the Port Townsend 30-by 60-minute quadrangle, Puget Sound region, Washington: U.S. Geological Survey Miscellaneous Investigations Map I-1198-E, scale 1:100,000.

Kincaid, T.M., and Olsen, A.R., 2013, spsurvey_-Spatial survey design and analysis $-\mathrm{R}$ package version 3.3: The Comprehensive R Archive Network web site, accessed May 21, 2018, at https://cran.r-project.org/web/packages/ spsurvey/spsurvey.pdf.

Komar, P.D., 1976, Beach processes and sedimentation: Englewood Cliffs, New Jersey, Prentice-Hall, 429 p.

Lanksbury, J., Lubliner, B., Langness, M., and West, J., 2017, Stormwater action monitoring 2015/16 mussel monitoring survey: Olympia, Washington Department of Fish and Wildlife, Report Number FPT 17-06, 115 p.

Larsen, D.P., Olsen, A.R., and Stevens, D.L., Jr., 2008, Using a master sample to integrate stream monitoring programs: Journal of Agricultural Biological and Environmental Statistics, v. 13, no. 3, p. 243-254, https:// doi.org/10.1198/108571108X336593. 
Liaw, A., and Wiener, M., 2002, Classification and regression by random forest: R News, v. 2/3, p. 18-22.

Long, E.R., Dutch, M., Aasen, S., Welch, K., and Hameedi, M.J., 2005, Spatial extent of degraded sediment quality in Puget Sound (Washington State, U.S.A.) based upon measures of the sediment quality triad: Environmental Monitoring and Assessment, v. 111, nos. 1-3, p. 173-222, https://doi.org/10.1007/s10661-005-8220-7.

McBride, A., Todd, S., Odum, O., Koschak, M., and Beamer, E., 2009, Developing a geomorphic model for nearshore habitat mapping and analysis: La Conner, Washington, Skagit River System Cooperative, 60 p.

Merritt, G., and Hartman, C., 2012, Status of Puget Sound tributaries 2009-Biology, chemistry and physical habitat: Washington State Department of Ecology, Publication No. 12-03-029, 102 p., https://fortress.wa.gov/ecy/publications/ summarypages/1203029.html.

Michelsen, T.C., 1992, Technical information memorandumOrganic carbon normalization of sediment data: Washington State Department of Ecology, Publication No. 05-09-050, $10 \mathrm{p}$.

Milesi, C., 2015, Stormwater facts: Puget Sound Institute, Encyclopedia of Puget Sound web page, accessed April 29, 2017, at https://www.eopugetsound.org/articles/stormwaterfacts.

Narquis, C.T., Hyatt, J.E., and Prignano, A.L., 2008, Generating the right data-Determination of Aroclors versus PCB congeners, in Waste Management Conference, 34th, Phoenix, Arizona, February 24-28, 2008, Proceedings: Richland, Washington, Fluor Hanford, Inc., 10 p.

National Oceanic and Atmospheric Administration, 2016, Laboratory methods for the analysis of microplastics in the marine environment - Recommendations for quantifying synthetic particles in waters and sediment: U.S. Department of Commerce Technical Memorandum NOS-OR\&R-48, $39 \mathrm{p}$.

Nordstrom, K.F., 1992, Estuarine beaches: New York, Elsevier, $225 \mathrm{p}$.

Olsen, A.R., Kincaid, T.M., and Quinn, P., 2012, Spatially balanced survey designs for natural resources, chap. 6 of Gibson, R., Millspaugh, J., Cooper, A., Licht, D., eds., Design and analysis of long-term ecological monitoring studies: Cambridge, United Kingdom, Cambridge University Press, p. 126-150, https://doi.org/10.1017/ CBO9781139022422.010.
O’Neill, S.M., and West, J.E., 2009, Marine distribution, life history traits, and the accumulation of polychlorinated biphenyls in Chinook salmon from Puget Sound, Washington: Transactions of the American Fisheries Society, v. 138 , no. 3, p. 616-632, https://doi.org/10.1577/T08-003.1.

Pascoe, G.A., McLaren, P., and Soldate, M., 2002, Impact of offsite sediment transport and toxicity on remediation of a contaminated estuarine bay: Marine Pollution Bulletin, v. 44, no. 11, p. 1184-1193, https://doi.org/10.1016/S0025326X(02)00125-X.

Pinedo, S., Jordana, E., Flagella, M.M., and Ballesteros, E., 2014, Relationships between heavy metals contamination in shallow marine sediments with industrial and urban development in Catalonia (Northwestern Mediterranean Sea): Water, Air, and Soil Pollution v. 225, no. 2084, p. 1-16.

Prasad, A.M., Iverson, L.R., and Liaw, A., 2006, Newer classification and regression tree techniques-Bagging and random forests for ecological prediction: Ecosystems, v. 9, no. 2, p. 181-199, https://doi.org/10.1007/s10021-0050054-1.

Puget Sound Action Team, 2005, State of the Sound 2004: Olympia, Washington, Puget Sound Action Team, Publication No. PSAT 05-01.

R Development Core Team, 2006, R-A language and environment for statistical computing: Vienna, Austria, R Foundation for Statistical Computing web page, ISBN 3-900051-07-0, http://www.R-project.org.

Rios, L.M., Moore, C., and Jones, P.R., 2007, Persistent organic pollutants carried by synthetic polymers in the ocean environment: Marine Pollution Bulletin, v. 54, no. 8, p. 1230-1237, https://doi.org/10.1016/j. marpolbul.2007.03.022.

Roper, B.B., Buffington, J.M., Bennett, S., Archer, E., Downie, S.T., Faustini, J., Hillman, T.W., Hubler, S., Jones, K., Jordan, C., Kaufmann, P.R., Merritt, G., Moyer, C., and Pleus, A., 2010, A comparison of the performance and compatibility of protocols used by seven monitoring groups to measure stream habitat in the Pacific Northwest: North American Journal of Fisheries Management, v. 30, no. 2, p. 565-587, https://doi. org/10.1577/M09-061.1.

Ross, P.S., Ellis, G.M., Ikonomou, M.G., Barrett-Lennard, L.G., and Addison, R.F., 2000, High PCB concentrations in freeranging Pacific killer whales, Orcinus orca-Effects of age, sex and dietary preference: Marine Pollution Bulletin, v. 40, no. 6, p. 504-515, https://doi.org/10.1016/S0025326X(99)00233-7. 
Roy, W.R., and Griffin, R.A., 1985, Mobility of organic solvents in water saturated soil materials: Environmental Geology and Water Sciences, v. 7, no. 4, p. 241-247, https:// doi.org/10.1007/BF02509925.

Shelton, L.R., and Capel, P.D., 1994, Guidelines for collection and processing samples of stream bed sediment for analysis of trace elements and organic contaminants for the National Water-Quality Assessment Program: U.S. Geological Survey Open-File Report 94-458, 20 p.

Simenstad, C.A., Ramirez, M., Burke, J., Logsdon, M., Shipman, H., Tanner, C., Toft, J., Craig, B., Davis, C., Fung, J., Bloch, P., Fresh, K., Myers, D., Iverson, E., Bailey, A., Schlenger, P., Kiblinger, C., Myre, P., Gerstel, W., and MacLennan, A., 2011, Historical change of Puget Sound shorelines-Puget Sound nearshore ecosystem project change analysis: Washington Department of Fish and Wildlife, Olympia, and U.S. Army Corps of Engineers, Seattle, Puget Sound Nearshore Report No. 2011-01, 289 p., http://www.pugetsoundnearshore.org/technical_papers/ change_analysis.pdf.

Sokal, R.R., and Rohlf, F.J., 1981, Biometry: New York, W.H. Freeman and Company, $859 \mathrm{p}$.

Stanley, S., Grigsby, S., Booth, D.B., Hartley, D., Horner, R., Hruby, T., Thomas, J., Bissonnette, P., Fuerstenberg, R., Lee, J., Olson, P., and Wilhere, G., 2016, Puget Sound characterization-Volume 1-The water resources assessments (water flow and water quality): Olympia, Washington State Department of Ecology, Publication No. 11-06-016, 69 p.

Stevens, D.L., Jr., 1997, Variable density grid-based sampling designs for continuous spatial populations: Environmetrics, v. 8, no. 3, p. 167-195, https://doi.org/10.1002/(SICI)1099095X(199705)8:3<167::AID-ENV239>3.0.CO;2-D.

Stevens, D.L., Jr., and Olsen, A.R., 1999, Spatially restricted surveys over time for aquatic resources: Journal of Agricultural, Biological, and Environmental Statistics, v. 4, no. 4, p. 415-428, https://doi.org/10.2307/1400499.

Stevens, D.L., Jr., and Olsen, A.R., 2003, Variance estimation for spatially balanced samples of environmental resources: Environmetrics, v. 14, no. 6, p. 593-610, https://doi. org/10.1002/env.606.

Stevens, D.L., Jr., and Olsen, A.R., 2004, Spatially balanced sampling of natural resources: Journal of the American Statistical Association, v. 99, no. 465, p. 262-278, https:// doi.org/10.1198/016214504000000250.
Stoddard, J.L., Peck, D.V., Olsen, A.R., Larsen, D.P., Van Sickle, J., Hawkins, C.P., Hughes, R.M., Whittier, T.R., Lomnicky, G.A., Herlihy, A.T., Kaufmann, P.R., Peterson, S.A., Ringold, P.L., Paulsen, S.G., and Blair, R., 2005, Environmental Monitoring and Assessment Program (EMAP) - Western streams and rivers statistical summary: U.S. Environmental Protection Agency, Office of Research and Development, Report Number EPA/620/R-05/006, $1762 \mathrm{p}$.

Stormwater Work Group of Puget Sound, 2010, 2010 stormwater monitoring and assessment strategy for Puget Sound Region: Stormwater Work Group of Puget Sound, 94 p., https://ecology.wa.gov/DOE/files/c2/c29ca31c-5d1344e8-91a5-a37b190b04fd.pdf.

Sussarellu, R., Suquet, M., Thomas, Y., Lambert, C., Fabioux, C., Pernet, M.E.J., Le Goïc, N.L., Quillien, V., Mingant, C., Epelboin, Y., Corporeau, C., Guyomarch, J., Robbens, J., Paul-Pont, I., Soudant, P., and Huvet, A., 2016, Oyster reproduction is affected by exposure to polystyrene microplastics: Proceedings of the National Academy of Sciences of the United States of America, v. 113, no. 9, p. 2430-2435, https://doi.org/10.1073/pnas.1519019113.

Tetra Tech, Inc., 1986, Recommended protocols for measuring conventional sediment variables in Puget Sound: Prepared for U.S. Environmental Protection Agency and Puget Sound Water Quality Authority, 44 p., http://citeseerx.ist.psu.edu/ viewdoc/download?doi=10.1.1.296.5665\&rep=rep1\&type $=$ pdf.

Tourinho, P.S., Ivar do Sul, J.A., and Fillmann, G., 2010, Is marine debris ingestion still a problem for the coastal marine biota of southern Brazil?: Marine Pollution Bulletin, v. 60, no. 3, p. 396-401, https://doi.org/10.1016/j. marpolbul.2009.10.013.

U.S. Environmental Protection Agency, 1997, The incidence and severity of sediment contamination in surface waters of the United States: U.S. Environmental Protection Agency, EPA 823-R-97-006.

U.S. Environmental Protection Agency, 2014, Record of decision-Lower Duwamish Waterway superfund site: U.S. Environmental Protection Agency, 165 p., https://semspub. epa.gov/work/10/715975.pdf.

Van den Berg, M., Birnbaum, L.S., Denison, M., De Vito, M., Farland, W., Feeley, M., Fiedler, H., Hakansson, H., Hanberg, A., Haws, L., Rose, M., Safe, S., Schrenk, D., Tohyama, C., Tritscher, A., Tuomisto, J., Tysklind, M., Walker, N., and Peterson, R.E., 2006, The 2005 World Health Organization reevaluation of human and mammalian toxic equivalency factors for dioxins and dioxin-like compounds: Toxicological Sciences, v. 93, no. 2, p. 223-241, https://doi.org/10.1093/toxsci/kfl055. 
Vianello, A., Boldrin, A., Guerriero, P., Moschino, V., Rella, R., Sturaro, A., and Da Ros, L., 2013, Microplastic particles in sediments of lagoon of Venice, ItalyFirst observations on occurrence, spatial patterns and identification: Estuarine, Coastal and Shelf Science, v. 130, p. 54-61, https://doi.org/10.1016/j.ecss.2013.03.022.

Wallace, R.S., 1988, Quantification of net shore-drift rates in Puget Sound and the Strait of Juan de Fuca, Washington: Journal of Coastal Research, v. 4, p. 395-403.

West, J.E., Lanksbury, J., and O’Neill, S.M., 2011, Persistent organic pollutants in marine plankton from Puget Sound: Olympia, Washington Department of Fish and Wildlife, Publication No. 11-10-002, 70 p.

West, J.E., Lanksbury, J., O’Neill, S.M., and Marshall, A., 2011, Persistent, bioaccumulative and toxic contaminants in pelagic marine fish species from Puget Sound: Olympia, Washington Department of Fish and Wildlife, Publication No. 11-10-003, 59 p.
West, J.E., O’Neill, S.M., Lippert, G.R., and Quinnell, S.R., 2001, Toxic contaminants in marine and anadromous fish from Puget Sound, Washington-Results from the Puget Sound Ambient Monitoring Program fish component, 1989-1999: Olympia, Washington Department of Fish and Wildlife, FTP01-14, 52 p. plus appendix.

West, J.E., O'Neill, S.M., and Ylitalo, G.M., 2008, Spatial extent, magnitude, and patterns of persistent organochlorine pollutants in Pacific herring (Clupea pallasi) populations in the Puget Sound (USA) and Strait of Georgia (Canada): The Science of the Total Environment, v. 394, nos. 2-3, p. 369-378, https://doi.org/10.1016/j.scitotenv.2007.12.027. 


\section{Appendixes}

Appendixes 1-6 are sheets in a Microsoft Excel ${ }^{\circledR}$ file that is available for download at https://doi.org/10.3133/sir20185076.

Appendix 1. Polybrominated Diphenyl Ethers (PDBEs), Polycyclic Aromatic Hydrocarbons (PAHs), Phthalates, and Metals Analyzed for in the Shoreline Action Monitoring Nearshore Sediment Study, Puget Sound, western Washington

Appendix 2. Total Organic Carbon and Total Polychlorinated Biphenyls (PCBs), Total of 12 Most Toxic PCBs, Toxicity EQuivalent Concentration (TEQ) of PCBs, Total Polybrominated Diphenyl Ethers (PBDEs), and Total Polycyclic Aromatic Hydrocarbons (PAHs) by Site, Puget Sound, western Washington

Appendix 3. Land-Cover, Geologic, and Drift Cell Attributes Used in the Random Forest Modeling and Drift Cell Analysis, Puget Sound, western Washington

Appendix 4. Concentrations of Individual Polycyclic Aromatic Hydrocarbons PAHs with Washington State Criteria by Site, Puget Sound, western Washington

Appendix 5. Concentrations of Individual Phthalates with Washington State Criteria by Site, Puget Sound, western Washington

Appendix 6. Metal Concentrations by Site, Puget Sound, western Washington 

Publishing support provided by the U.S. Geological Survey

Science Publishing Network, Tacoma Publishing Service Center

For more information concerning the research in this report, contact the Director, Washington Water Science Center

U.S. Geological Survey

934 Broadway, Suite 300

Tacoma, Washington 98402

https://wa.water.usgs.gov 


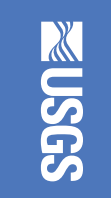

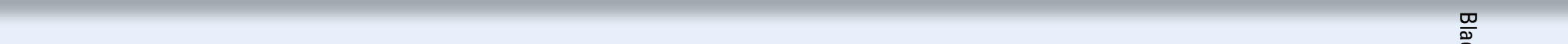

